OPEN ACCESS

Edited by:

Jonathan Mapelli,

University of Modena and Reggio

Emilia, Italy

Reviewed by:

Mauricio Di Fulvio,

Wright State University, United States Klaus-Peter Hoffmann,

University Hospitals of the

Ruhr-University of Bochum, Germany lan Duguid,

University of Edinburgh,

United Kingdom

*Correspondence:

Negah Rahmati

nrahmatiandami@mgh.harvard.edu

tPresent Address:

Negah Rahmati, Department of Neurology, Massachusetts General Hospital and Harvard Medical School, Boston, MA, United States

Received: 17 November 2017 Accepted: 28 March 2018 Published: 01 May 2018

Citation:

Rahmati N, Hoebeek FE, Peter S and

De Zeeuw Cl (2018) Chloride Homeostasis in Neurons With Special Emphasis on the Olivocerebellar System: Differential Roles for Transporters and Channels. Front. Cell. Neurosci. 12:101. doi: 10.3389/fncel.2018.00101

\section{Chloride Homeostasis in Neurons With Special Emphasis on the Olivocerebellar System: Differential Roles for Transporters and Channels}

\author{
Negah Rahmati ${ }^{1 \star \dagger}$, Freek E. Hoebeek ${ }^{1,2}$, Saša Peter ${ }^{1}$ and Chris I. De Zeeuw ${ }^{1,3}$ \\ ${ }^{1}$ Department of Neuroscience, Erasmus Medical Center, Rotterdam, Netherlands, ${ }^{2}$ NIDOD Institute, Wilhelmina Children's \\ Hospital, University Medical Center Utrecht and Brain Center Rudolf Magnus, Utrecht, Netherlands, ${ }^{3}$ Netherlands Institute for \\ Neuroscience, Royal Dutch Academy for Arts and Sciences, Amsterdam, Netherlands
}

The intraneuronal ionic composition is an important determinant of brain functioning. There is growing evidence that aberrant homeostasis of the intracellular concentration of $\mathrm{Cl}^{-}\left(\left[\mathrm{Cl}^{-}\right]_{\mathrm{i}}\right)$ evokes, in addition to that of $\mathrm{Na}^{+}$and $\mathrm{Ca}^{2+}$, robust impairments of neuronal excitability and neurotransmission and thereby neurological conditions. More specifically, understanding the mechanisms underlying regulation of $\left[\mathrm{Cl}^{-}\right]_{\mathrm{i}}$ is crucial for deciphering the variability in GABAergic and glycinergic signaling of neurons, in both health and disease. The homeostatic level of $\left[\mathrm{Cl}^{-}\right]_{i}$ is determined by various regulatory mechanisms, including those mediated by plasma membrane $\mathrm{Cl}^{-}$channels and transporters. This review focuses on the latest advances in identification, regulation and characterization of $\mathrm{Cl}^{-}$channels and transporters that modulate neuronal excitability and cell volume. By putting special emphasis on neurons of the olivocerebellar system, we establish that $\mathrm{Cl}^{-}$channels and transporters play an indispensable role in determining their $\left[\mathrm{Cl}^{-}\right]_{\mathrm{i}}$ and thereby their function in sensorimotor coordination.

Keywords: chloride homeostasis, chloride transporters and channels, GABAergic inhibition, olivocerebellar system, cerebellar motor learning

\section{CHLORIDE REGULATION IN BRAIN CELLS}

Chloride $\left(\mathrm{Cl}^{-}\right)$is the most abundant transportable anion in all cells of the body and it performs fundamental biological functions in all tissues. The intracellular concentration of chloride $\left(\left[\mathrm{Cl}^{-}\right]_{\mathrm{i}}\right)$ is regulated and maintained by a delicate functional balance between the operations of plasma membrane $\mathrm{Cl}^{-}$channels and those of transporters, as well as those of local impermeant anions (Rivera et al., 1999; Glykys et al., 2014). In the central nervous system, $\mathrm{Cl}^{-}$channels and transporters play key roles in neuronal growth and development, neurotransmitter uptake, intracellular $\mathrm{pH}$ modulation, cell volume regulation and, perhaps most importantly, setting $\left[\mathrm{Cl}^{-}\right]_{\mathrm{i}}$ either above or below its equilibrium potential (Sangan et al., 2002; Deidda et al., 2014; Ruffin et al., 2014; Jentsch, 2016; Glykys et al., 2017). In addition, $\left[\mathrm{Cl}^{-}\right]_{\mathrm{i}}$ plays a crucial role in moderating neuronal excitability by determining the postsynaptic responses to the neurotransmitters GABA and glycine (Ben-Ari et al., 2007; Branchereau et al., 2016; Doyon et al., 2016). One of the most studied roles of $\left[\mathrm{Cl}^{-}\right]_{\mathrm{i}}$ in neurons is its modulatory function in postsynaptic responses evoked by activation of ligandgated $\mathrm{Cl}^{-}$channels, such as $\mathrm{GABA}_{\mathrm{A}}$ receptors $\left(\mathrm{GABA}_{\mathrm{A}} \mathrm{Rs}\right)$ (Bormann et al., 1987). The direction of the $\mathrm{Cl}^{-}$flow depends on the difference between the reversal potential of $\mathrm{Cl}^{-}\left(\mathrm{E}_{\mathrm{Cl}}\right)$ 
and the resting membrane potential (RMP) (Figure 1B). If $\mathrm{E}_{\mathrm{Cl}}$ is negative compared to the RMP of the neuron, $\mathrm{Cl}^{-}$flows inside the neuron. $\mathrm{GABA}_{\mathrm{A}} \mathrm{Rs}$ in these types of cells mediate inward (hyperpolarizing) $\mathrm{Cl}^{-}$currents, which in turn lead to inhibition of the postsynaptic neuronal activity (Figure 1Ba). In contrast, if $\mathrm{E}_{\mathrm{Cl}}$ becomes more positive compared to the RMP, outward (depolarizing) $\mathrm{Cl}^{-}$flow through $\mathrm{GABA}_{\mathrm{A}}$ Rs leads to excitation of the postsynaptic neuron (Figure 1Bc). Therefore, the activities of $\mathrm{Cl}^{-}$channels and transporters that regulate $\left[\mathrm{Cl}^{-}\right]_{\mathrm{i}}$ are critical for determining the polarity of the impact of $\mathrm{GABA}_{\mathrm{A}} \mathrm{Rs}$ on the neuronal membrane potential.

Mutations or deletions of $\mathrm{Cl}^{-}$channels and transporters in the brain have been linked to genetic disorders, such as particular forms of neonatal seizures and epilepsy, ataxia, hyperekplexia (startle disease), and autism spectrum disorders (Cohen et al., 2002; Vermeer et al., 2010; Pizzarelli and Cherubini, 2011; Deidda et al., 2014). In addition, impaired $\mathrm{Cl}^{-}$homeostasis has been associated with pathology of the brain following acute injuries, such as hypoxic-ischemic encephalopathy, brain edema, and post-traumatic seizures (Galeffi et al., 2004; Jin et al., 2005; Pond et al., 2006; Papp et al., 2008). Therefore, targeting $\mathrm{Cl}^{-}$ channels/transporters has been investigated as a therapeutic tool for re-balancing neuronal $\left[\mathrm{Cl}^{-}\right]_{\mathrm{i}}$ and rescuing the consequential neurological symptoms. One example of such a $\mathrm{Cl}^{-}$based intervention is dampening the elevation of $\left[\mathrm{Cl}^{-}\right]_{\mathrm{i}}$ following traumatic brain injury (TBI), so as to prevent further neuronal swelling, excitatory GABA signaling, and seizure susceptibility (Annegers et al., 1998; Hung and Chen, 2012). Developing drugs that specifically target $\mathrm{Cl}^{-}$channels or transporters may thereby not only ameliorate the short-term pathological processes induced by TBI, but also the long-term behavioral consequences (Rungta et al., 2015; Ben-Ari, 2017).

Chloride channels and transporters may become activated in response to membrane potential changes (such as $\mathrm{ClC}$ channels), intracellular $\mathrm{Ca}^{2+}$ signaling (such as anoctaminchannels), and changes in intracellular pH (SLC4 and SLC26). In addition, $\mathrm{Cl}^{-}$is transported across the membrane by cation-chloride co-transporters (CCCs), like the $\mathrm{Na}^{+}-\mathrm{K}^{+}-\mathrm{Cl}^{-}$ cotransporter (NKCC1), and $\mathrm{K}^{+}-\mathrm{Cl}^{-}$cotransporters (KCCs). Investigating the impact of such a rich set of widely expressed ion channels/transporters on neuronal functioning is a complex matter, not in the least because of the heterogeneity of the neuronal populations and the diverse functional interactions of $\mathrm{Cl}^{-}$channels/transporters with each other and other ion carriers.

To allow an in-depth review of the functionality of neuronal $\mathrm{Cl}^{-}$channels and transporters, we focus here on their impact on the olivocerebellar system. This interconnected brain network has been investigated in detail over the past decades and the extensive anatomical, electrophysiological, and behavioral datasets provide a remarkably detailed view of the properties of olivocerebellar circuitry, rendering it a suitable model for studying the consequences of abnormalities in $\mathrm{Cl}^{-}$homeostasis at the cellular and network level. In order to set the stage, we will first provide a synopsis on the anatomical blueprint of the olivocerebellar system and highlight several hotspots where $\mathrm{Cl}^{-}$homeostasis has been shown to be crucial for proper functioning. Thereafter we will discuss in detail several families of $\mathrm{Cl}^{-}$channels and transporters and provide a concise view of the status quo in experimental studies. Hereby we hope to guide future translational investigations that aim to improve therapeutic strategies of $\mathrm{Cl}^{-}$based treatments.

\section{SIGNIFICANCE OF CHLORIDE IN THE OLIVOCEREBELLAR NETWORK}

The olivocerebellar system consists of three key regions: cerebellar cortex $(\mathrm{CX})$, cerebellar nuclei $(\mathrm{CN})$, and inferior olive (IO). A large part of the neuronal interactions in this network depends on GABAergic signaling (Figure 1A; Andersson et al., 1988; Angaut and Sotelo, 1989; De Zeeuw et al., 1989, 1998; Fredette and Mugnaini, 1991). The output of the cerebellar cortex is exclusively mediated by GABAergic Purkinje cells (PCs). Several of the PC's downstream target neurons in the $\mathrm{CN}$ are also GABAergic who in turn inhibit neurons in the IO and cerebellar cortex (Lefler et al., 2014; Ankri et al., 2015). Another source of inhibition in the cerebellar cortex is the molecular layer interneurons (MLIs), which are not only activated by synaptic excitation from granule cells, but also by non-synaptic glutamatespillover from IO axons, i.e., climbing fibers (CFs). MLIs synapse on either the somatic or dendritic membrane of PCs and thereby control PC action potential firing patterns (Figure 1A; Szapiro and Barbour, 2007). Aberrant GABAergic signaling at any of these synapses has been shown to evoke abnormalities in acquisition, correction, and timing of movements and thereby disrupt motor behavior (Bengtsson and Hesslow, 2006; Wulff et al., 2009; Seja et al., 2012; Rahmati et al., 2016). To the same extent, impairments of PC activity have been recently linked to autistic traits and other non-motor behaviors (Tsai et al., 2012; Peter et al., 2016).

It is particularly well-documented that the MLI to PC input determines the regularity and frequency of PC action potential firing (Häusser and Clark, 1997; Wulff et al., 2009) and that the MLI-mediated inhibition depends on the $\left[\mathrm{Cl}^{-}\right]_{\mathrm{i}}$ of PCs (Seja et al., 2012; Rahmati et al., 2016). Therefore, malfunction or deletion of GABAergic inhibitory input from MLIs to PCs leads to altered temporal firing patterns of PCs and causes various behavioral phenotypes in animal models (Wisden et al., 2009; Wulff et al., 2009; Seja et al., 2012; Rahmati et al., 2016). Likewise, in the olivary neurons the $\left[\mathrm{Cl}^{-}\right]_{\mathrm{i}}$ modulates their excitability and thereby the excitation of PCs, CNs, and MLIs as mediated by their CFs (Szapiro and Barbour, 2007; Zhang et al., 2017). Altered neuronal excitability in IO evokes longterm changes in the activity of cerebellar neurons and the spatiotemporal firing pattern of the olivocerebellar network (De Zeeuw et al., 2011). The impact of $\left[\mathrm{Cl}^{-}\right]_{\mathrm{i}}$ on GABAergic signaling in the olivocerebellar circuitry is also remarkable for its role in controlling the electrical coupling among olivary neurons. It has been proposed that activation of the GABAergic input from the $\mathrm{CN}$ to the IO leads to a reduction of coupling, whereas blocking this input increases IO coupling (De Zeeuw et al., 2011; De Gruijl et al., 2014; Lefler et al., 2014). Thus, various cellular components of the olivocerebellar system appear highly sensitive to $\left[\mathrm{Cl}^{-}\right]_{\mathrm{i}}$ disruptions by mutations in plasma membrane $\mathrm{Cl}^{-}$ 


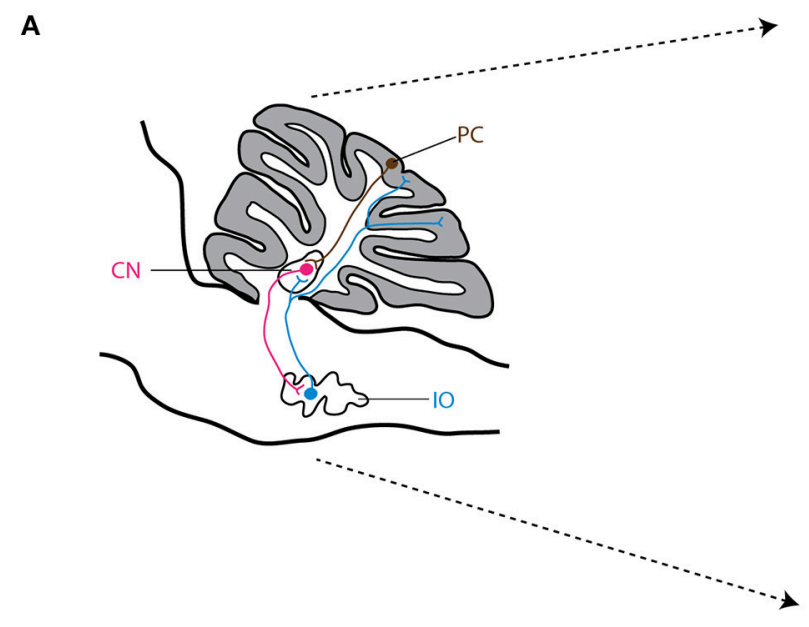

B
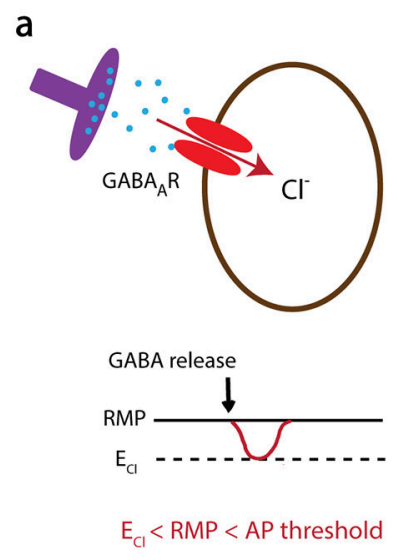

Hyperpolarizing GABA b
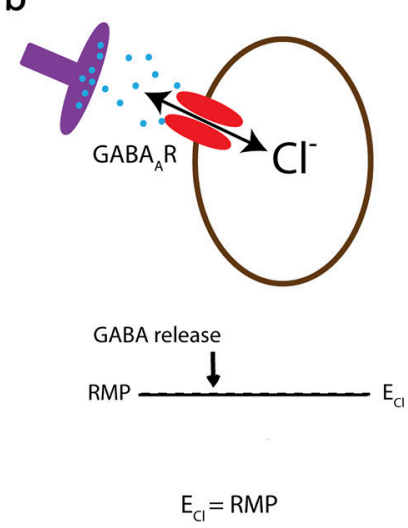

$\mathrm{Cl}^{-}$at equilibrium

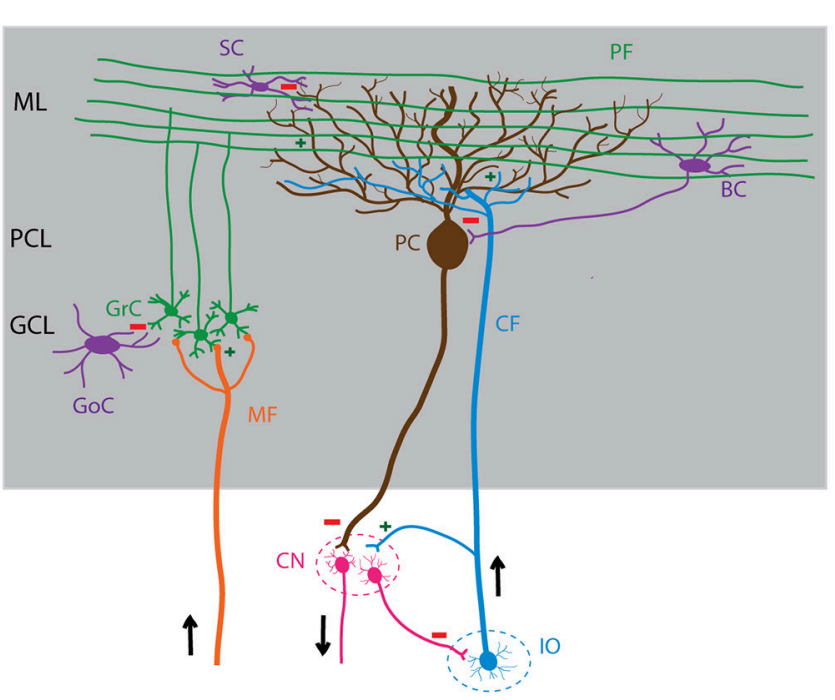

C
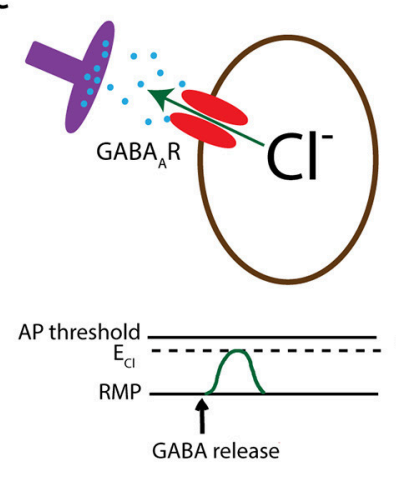

AP threshold $>E_{\mathrm{Cl}}>\mathrm{RMP}$

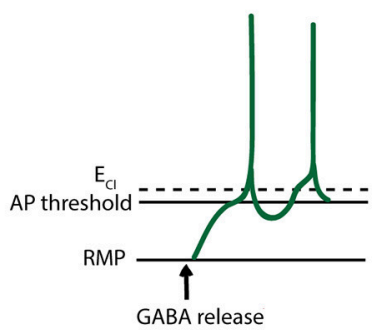

$\mathrm{E}_{\mathrm{Cl}}>\mathrm{AP}$ threshold $>\mathrm{RMP}$

Depolarizing GABA

FIGURE 1 | GABAergic signaling in olivo-cerebellar circuit. (A) Schematic representation of a sagittal section of the mouse olivo-cerebellar system (left). Inferior olivary neurons (shown in blue) project to the cerebellar cortex (gray) and excite Purkinje cells (brown), as well as the deeply located cerebellar nuclei (CN) neurons (pink). A particular subset of $\mathrm{CN}$ neurons projects back to the inferior olive $(\mathrm{IO})$, forming the olivo-cortico-nuclear loop. The right panel demonstrates the anatomical circuit of the cerebellar cortical neurons and their connectivity with CN and the IO. ML, molecular layer; PCL, Purkinje cell layer; GCL, granule cell layer; PC, Purkinje cell; GrC, granule cell; SC, stellate cell; BC, basket cell; GoC, Golgi cell; PF, parallel fiber; CF, climbing fiber; MF, mossy fiber; CN, cerebellar nuclei; IO, inferior olive. (B) The level

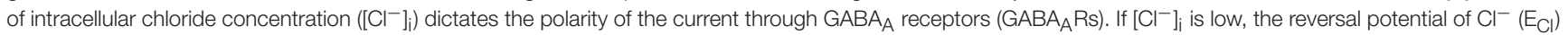

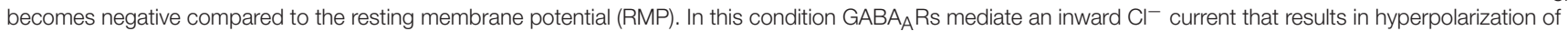
the cell membrane (a). In contrast, high $\left[\mathrm{Cl}^{-}\right]_{i}$ results in a positive shift of $\mathrm{E}_{\mathrm{Cl}}$ and leads to an outward $\mathrm{Cl}^{-} \mathrm{current}$ through $\mathrm{GABA}_{\mathrm{A}} \mathrm{R}$ and depolarization of the cell membrane that potentially induces action potential firing (c). In conditions where $\mathrm{E}_{\mathrm{Cl}}$ shifts to values similar to $\mathrm{RMP}$, there will be no net $\mathrm{Cl}^{-}$current through $\mathrm{GABA}_{A} \mathrm{Rs}(\mathrm{b})$.

transporters and channels. Below we review the studies that investigated the effects of mutations and functional deletions of some of these proteins on $\left[\mathrm{Cl}^{-}\right]_{\mathrm{i}}$, which in many cases altered neuronal excitability, action potential firing patterns and motor coordination.

\section{VOLTAGE-GATED $\mathrm{CL}^{-}$CHANNELS (CLC FAMILY)}

$\mathrm{ClC}$ isoforms exhibit unique cellular expression patterns, with certain members ( $\mathrm{ClC}-1$ and $\mathrm{ClC}-2)$ primarily detected in plasma membrane, whereas some other members (ClC-3 to ClC-7) predominantly distributed in intracellular organelles and vesicles. Functional studies indicate that plasma membranebound $\mathrm{ClCs}$ operate in $\mathrm{Cl}^{-}$channel mode and play a role in stabilizing membrane potential and/or $\mathrm{Cl}^{-}$concentration across the membrane, while the intracellular organelles' ClCs function as electrogenic $\mathrm{Cl}^{-} / \mathrm{H}^{+}$exchangers and facilitate endosomal and vesicular acidification (Jentsch et al., 2002; Jentsch, 2008, 2015; Bi et al., 2013). Many ClCs have not been studied in great detail for their function in the brain, but rather in other organs, including kidney where their malfunctions or deletions have been linked to various diseases in human (see Table $\mathbf{1}$ for further references 
TABLE 1 | ClC family of voltage-gated $\mathrm{Cl}^{-}$channels.

\begin{tabular}{|c|c|c|c|c|c|c|}
\hline ClCs & Expression & Function & Human disease & KO mouse & Pharmacology & References \\
\hline $\mathrm{ClC}-1$ & $\begin{array}{l}\text { Skeletal muscle, } \\
\text { smooth muscle, heart, } \\
\text { brain? }\end{array}$ & $\begin{array}{l}\text { Stabilizing membrane } \\
\text { potential in muscle }\end{array}$ & Myotonia congenita & $\begin{array}{l}\text { Myotonia congenita, } \\
\text { altered neuronal } \\
\text { excitability }\end{array}$ & $\begin{array}{l}\text { Inhibitors: } \mathrm{Zn}^{2+} \text { and } \mathrm{Cd}^{2+} \text {, } \\
\text { 9-AC, DPC, and niflumic } \\
\text { acid }\end{array}$ & $\begin{array}{l}\text { Lorenzetto et al., 2009; } \\
\text { Chen et al., 2013; } \\
\text { Imbrici et al., } 2015\end{array}$ \\
\hline $\mathrm{ClC}-2$ & $\begin{array}{l}\text { Broad (brain, heart, } \\
\text { muscle, kidney,...) }\end{array}$ & $\begin{array}{l}\text { Transepithelial transport, } \\
\text { cell volume control, } \\
\text { neuronal excitability }\end{array}$ & $\begin{array}{l}\text { Cardiovascular disease, } \\
\text { epilepsy? }\end{array}$ & $\begin{array}{l}\text { Leukoencephalopathy, } \\
\text { degeneration of retina } \\
\text { and testis, altered } \\
\text { neuronal excitability }\end{array}$ & $\begin{array}{l}\text { Inhibitors: } \mathrm{Zn}^{2+} \text { and } \mathrm{Cd}^{2+} \\
\text { DIDS, SITS }\end{array}$ & $\begin{array}{l}\text { Smith et al., 1995; } \\
\text { Clayton et al., 1998; } \\
\text { Rinke et al., 2010; } \\
\text { Ratté and Prescott, } \\
2011\end{array}$ \\
\hline $\mathrm{ClC}-3$ & $\begin{array}{l}\text { Broad (brain, heart, } \\
\text { muscle, kidney,...) }\end{array}$ & $\begin{array}{l}\text { Vesicular and endosomal } \\
\text { acidification }\end{array}$ & $?$ & $\begin{array}{l}\text { Hippocampal neuronal } \\
\text { degeneration, } \\
\text { degeneration of retina }\end{array}$ & & $\begin{array}{l}\text { Kawasaki et al., 1994; } \\
\text { Borsani et al., } 1995\end{array}$ \\
\hline $\mathrm{ClC}-5$ & Kidney, intestine & Endosomal acidification & Dent's disease & $\begin{array}{l}\text { Defects in renal } \\
\text { endocytosis, } \\
\text { proteinuria, } \\
\text { hyperphosphaturia }\end{array}$ & & $\begin{array}{l}\text { Günther et al., 1998; } \\
\text { Schwake et al., 2001; } \\
\text { Vandewalle et al., } 2001\end{array}$ \\
\hline $\mathrm{ClC}-6$ & Brain & Endosomal acidification & $?$ & $\begin{array}{l}\text { Lysosomal storage } \\
\text { disease }\end{array}$ & & $\begin{array}{l}\text { Brandt and Jentsch, } \\
\text { 1995; Poët et al., } 2006\end{array}$ \\
\hline $\mathrm{ClC}-7$ & $\begin{array}{l}\text { Broad (brain, bone, } \\
\text { kidney,...) }\end{array}$ & $\begin{array}{l}\text { Lysosomal } \mathrm{Cl}^{-} \\
\text {regulation, acidification of } \\
\text { osteoclast, resorption } \\
\text { lacunae }\end{array}$ & $\begin{array}{l}\text { Osteopetrosis, neuronal } \\
\text { ceroid lipofuscinosis, retinal } \\
\text { degeneration, lysosomal } \\
\text { storage disease }\end{array}$ & $\begin{array}{l}\text { Lysosomal storage } \\
\text { disease, retinal } \\
\text { degeneration, } \\
\text { osteopetrosis }\end{array}$ & & $\begin{array}{l}\text { Brandt and Jentsch, } \\
\text { 1995; Kornak et al., } \\
\text { 2001; Kasper et al., } \\
2005\end{array}$ \\
\hline $\mathrm{ClC}-\mathrm{Kb}$ & Kidney, inner ear & $\begin{array}{l}\text { Transepithelial transport, } \\
\text { salt reabsorption }\end{array}$ & Bartter syndrome type III & Salt loss, deafness & $\begin{array}{l}\text { Inhibited by } \\
\text { phenylbenzofuran } \\
\text { carboxylic acids }\end{array}$ & $\begin{array}{l}\text { Kobayashi et al., 2002; } \\
\text { Jeck et al., 2004; Frey } \\
\text { et al., } 2006\end{array}$ \\
\hline
\end{tabular}

and information regarding the members of the ClC-family). Below, we focus on the roles of $\mathrm{ClC}-1, \mathrm{ClC}-2$, and $\mathrm{ClC}-3$ in the olivocerebellar system.

\section{CIC-1}

ClC-1, which is a plasma membrane-bound chloride channel encoded by the CLCN-1 gene, is particularly known for its high $\mathrm{Cl}^{-}$conductance, its expression in skeletal muscles, and its genetic mutations causing myotonia congenita (Jentsch, 2008). Recent studies have also identified mRNA and protein expression of $\mathrm{ClC}-1$ in neuronal tissue, including pyramidal and dentate granule cells of the hippocampus, brain stem nuclei, thalamic nuclei, frontal neocortex, as well as cerebellar PCs (Chen et al., 2013; Imbrici et al., 2015). The presence of polymorphic alleles in $C L C N-1$ gene in patients with idiopathic epilepsy underscores an important role for this $\mathrm{Cl}^{-}$channel in neurological diseases (Chen et al., 2013). Although the precise pathophysiological mechanisms of ClC-1 channel mutations in epilepsy remain unknown, overexpression of ClC-1 in the inhibitory PCs has been found to hyperpolarize their resting membrane potential and reduce their excitability (Lorenzetto et al., 2009), which in turn may well lead to disinhibition of the $\mathrm{CN}$ and thereby influence epileptogenesis (Kros et al., 2015). Given that overexpression of ClC-1 even enhances inwardly rectifying $\mathrm{Cl}^{-}$currents during depolarization in Xenopus oocytes, the impact on the membrane potential observed in PCs may also hold for other neurons (Steinmeyer and Klocke, 1991; Jentsch et al., 2002). One more unique impact of $\mathrm{ClC}-1$ overexpression appears to be on synapse elimination. PCs overexpressing $\mathrm{ClC}-1$ show a delayed elimination of their supernumerary CF inputs during development (Crepel et al., 1976; Hashimoto and Kano, 2005; Hashimoto et al., 2011); in normal wild type animals this process is finalized by the end of the third postnatal week, whereas in ClC-overexpressing transgenic mice it lasts at least 3 months (Lorenzetto et al., 2009). Thus, these studies provide supportive evidence for a contribution of voltage-gated $\mathrm{Cl}^{-}$channels to the maturation of neuronal networks and neuronal excitability, and suggest that their function is critical to prevent neurological disorders such as epilepsy (Imbrici et al., 2015).

\section{CIC-2}

ClC-2, which is a plasma membrane-bound chloride channel encoded by the CLCN-2 gene, is broadly expressed in the body with a wide range of functions, including regulation of cell volume and extracellular $\mathrm{pH}$. In the brain, ClC-2 is expressed in different types of neurons, including pyramidal cells of the hippocampus and PCs of the cerebellum (Smith et al., 1995; Clayton et al., 1998), as well as in glia cells, like Bergmann glia in the cerebellar cortex (Sík et al., 2000; Blanz et al., 2007; Planells-Cases and Jentsch, 2009). In olivocerebellar system, ClC-2 knockout mice show the typical progressive spongiform vacuolation of their white matter tracts, which in the rest of the brain is manifested as leuko-encephalopathy (Blanz et al., 2007). Although no study has yet specifically examined the cell physiological role of $\mathrm{ClC}-2$ in cerebellar neurons, several studies have evaluated its function in mediating the inwardly rectifying $\mathrm{Cl}^{-}$current in hippocampal pyramidal cells (Weinreich and Jentsch, 2001; Rinke et al., 2010). Under conditions of high 
$\left[\mathrm{Cl}^{-}\right]_{\mathrm{i}}$, i.e., those found in dorsal root ganglion cells and hippocampal neurons of rats with temporal lobe epilepsy, $\mathrm{ClC}$ 2 channels have been shown to extrude $\mathrm{Cl}^{-}$(Staley et al., 1996; Ge et al., 2011). Endogenously, neuronal ClC-2 is open at resting membrane potentials and it does not inactivate or close at a given time upon activation (Staley et al., 1996). Thereby, it also has a profound effect on the membrane resistance, action potential threshold, and neuronal excitability (Madison et al., 1986; Rinke et al., 2010; Ratté and Prescott, 2011). However, ClC2 knockout mice do not show lowered seizure susceptibility levels in their temporal lobe compared to their wild type littermates (Rinke et al., 2010). One possible explanation may be that the hyperexcitability of part of their neurons was balanced out by increased excitability of their local inhibitory interneurons (Rinke et al., 2010). Similar compensatory mechanisms may also occur in the olivocerebellar network, as ClC-2 KO mice do not show obvious abnormalities in movement performance (Blanz et al., 2007). Alternatively, it is also plausible that up and/or downregulation of other $\mathrm{Cl}^{-}$channels (for instance ClC-1) can compensate for deletion of $\mathrm{ClC}-2$.

\section{CIC-3}

ClC-3, which is a $\mathrm{Cl}^{-} / \mathrm{H}^{+}$exchanger encoded by the CLCN3 gene, is broadly expressed in many tissues, including brain, kidney, skeletal muscles, heart, and liver (Kawasaki et al., 1994; Borsani et al., 1995; Jentsch et al., 2002). It shows ubiquitous expression throughout the brain with some of the highest levels of expression in hippocampus and cerebellum (2004 Allen Institute for Brain Science; Allen Human Brain Atlas. Available from: mouse.brain-map.org). With regard to the cellular distribution of ClC-3, the existing literature points to predominant expression in endosomal compartments and synaptic vesicles where it contributes to acidification by mediating the exchange of $\mathrm{Cl}^{-}$ against protons (Stobrawa et al., 2001). However, its expression in plasma membrane has been the subject of conflicting reports (Li et al., 2000; Jentsch et al., 2002). Recent studies by Nelson and colleagues showed that $\mathrm{ClC}-3$ is expressed in the plasma membrane of postsynaptic hippocampal neurons, where it is functionally linked to NMDA receptors and activated by CaMKII (Wang et al., 2006; Farmer et al., 2013). In addition, ClC3 may participate in controlling $\mathrm{Ca}^{2+}$ influx and plasticity in hippocampal neurons (Farmer et al., 2013). ClC-3 knock-out mice show postnatal degeneration of the retina and hippocampus (Stobrawa et al., 2001). In the cerebellum, expression is high in PCs (2004 Allen Institute for Brain Science; Allen Human Brain Atlas. Available from: mouse.brain-map.org). According to the studies by Farmer and colleagues, it is tempting to hypothesize that $\mathrm{ClC}-3$ may also play a role in controlling plasticity at the $\mathrm{PF}$ to $\mathrm{PC}$ synapse by reducing $\mathrm{Ca}^{2+}$ influx. However, it has not been established yet whether $\mathrm{ClC}-3$ is also expressed in the plasma membrane of PCs.

\section{2. $\mathrm{CA}^{2+}$-ACTIVATED $\mathrm{CL}^{-}$CHANNELS (ANOCTAMINS)}

The intracellular $\mathrm{Ca}^{2+}$ concentration $\left(\left[\mathrm{Ca}^{2+}\right]_{\mathrm{i}}\right)$ plays a vital role in cellular signal transduction pathways, neurotransmitter release, as well as cellular excitability (Fakler and Adelman, 2008; Greer and Greenberg, 2008). Voltage-gated $\mathrm{Ca}^{2+}$ channels, which open upon membrane depolarization, form the main source of $\mathrm{Ca}^{2+}$ influx, but intracellular $\mathrm{Ca}^{2+}$-stores also contribute to elevating $\left[\mathrm{Ca}^{2+}\right]_{i}$. The increase of $\left[\mathrm{Ca}^{2+}\right]_{\mathrm{i}}$ is the prime activator for $\mathrm{Ca}^{2+}$-activated ion channels, including the large- $\left(\mathrm{K}_{\mathrm{Ca}}, \mathrm{BK}\right)$ and small-conductance $\left(\mathrm{K}_{\mathrm{Ca}}, \mathrm{SK}\right) \mathrm{Ca}^{2+}{ }_{-}$ activated $\mathrm{K}^{+}$channels. BK and SK channels are well-known for their predominant effects on the repolarization of the membrane following an action potential, influencing intrinsic excitability and shaping the postsynaptic currents, such as those of dendritic $\mathrm{Ca}^{2+}$ spikes (Fakler and Adelman, 2008). In addition to the $\mathrm{K}_{\mathrm{Ca}}$ channels, several in vitro electrophysiological studies have shown the existence of a range of $\mathrm{Ca}^{2+}$-activated $\mathrm{Cl}^{-}$currents $\left(\mathrm{Cl}_{\mathrm{Ca}}\right)$, which can, depending on the $\left[\mathrm{Cl}^{-}\right]_{i}$, depolarize or repolarize the membrane potential. One of the main families of $\mathrm{Ca}^{2+}$ activated $\mathrm{Cl}^{-}$channels is the TMEM16 family (also referred to as anoctamins), which contains 10 members (Ano1-10), most of which are present in many different cell types in the body. In addition to their ion channel activity, anoctamins have been implicated in a wide range of physiological tasks, such as phospholipid scrambling or regulation of specific $\mathrm{K}^{+}$channels (Suzuki et al., 2010; Huang et al., 2013a,b; Picollo et al., 2015). As a consequence, anoctamins have been attributed to various functionalities, such as smooth muscle contraction, olfactory and sensory signal transduction, and neuronal excitability (Picollo et al., 2015). Not surprisingly, the clinical implications of impaired TMEM16 activity is equally diverse in that patients with mutated anoctamins are associated with cancer (Duvvuri et al., 2012; Liu et al., 2012; Ubby et al., 2013; Guan et al., 2016), muscular dystrophy (Griffin et al., 2016), Scott syndrome (Suzuki et al., 2010), and autosomal recessive cerebellar ataxia (Vermeer et al., 2010).

In line with their de- or repolarizing impact on the membrane potential, opening of anoctamins leads to $\mathrm{Cl}^{-}$efflux or influx depending on the gradient of $\mathrm{Cl}^{-}$across the cell membrane. For instance, in olfactory and dorsal root ganglion (DRG) neurons with high $\left[\mathrm{Cl}^{-}\right]_{\mathrm{i}}, \mathrm{Cl}^{-}$efflux through anoctamins amplifies the sensory signal transduction by depolarizing the cell (Stephan et al., 2009; Cho et al., 2012). In contrast, in hippocampal pyramidal cells and IO neurons, which typically have relatively low $\left[\mathrm{Cl}^{-}\right]_{i}$, anoctamins cause hyperpolarization by mediating $\mathrm{Cl}^{-}$influx (Huang et al., 2012; Zhang et al., 2017). It should be noted that not all anoctamins have yet been characterized as a $\mathrm{Cl}_{\mathrm{Ca}}$ channel. So far Ano1, Ano2, and Ano6 have been shown to gate $\mathrm{Cl}^{-}$dependent on $\mathrm{Ca}^{2+}$-activation, albeit with variable affinities for $\mathrm{Ca}^{2+}$. For example, Anol exhibits a higher affinity for $\mathrm{Ca}^{2+}$ and a longer de-activation time than Ano2, while Ano6 appears to have a very low affinity for $\mathrm{Ca}^{2+}$ (Pifferi et al., 2009; Stephan et al., 2009; Grubb et al., 2013).

Anoctamins start gating $\mathrm{Cl}^{-}$fluxes upon a rise in $\left[\mathrm{Ca}^{2+}\right]_{\mathrm{i}}$ evoked by the opening of voltage-gated $\mathrm{Ca}^{2+}$ channels and release from internal $\mathrm{Ca}^{2+}$-stores. Both Ano1 and Ano2 have been shown to interact with $\mathrm{Ca}^{2+}$ driven calmodulin complexes (Verkman and Galietta, 2009; Jung et al., 2013; Vocke et al., 2013). Additional layers of complexity are added by the observations that Ano1 does not have to be activated by a postsynaptic $\mathrm{Ca}^{2+}$ influx per se, but can also be activated locally 
TABLE 2 | TMEM16 (Anoctamin) family.

\begin{tabular}{|c|c|c|c|c|c|c|}
\hline \multicolumn{2}{|c|}{ AnoctaminsExpression } & \multirow{2}{*}{$\begin{array}{l}\text { Function } \\
\mathrm{Cl}_{\mathrm{Ca}} \text { channel, involved } \\
\text { in fluid secretion, } \\
\text { muscle contraction, } \\
\text { gastrointestinal } \\
\text { contractility, pain } \\
\text { processing }\end{array}$} & \multirow{2}{*}{$\begin{array}{l}\text { Human disease } \\
\text { Tumor growth, cystic } \\
\text { fibrosis, asthma }\end{array}$} & \multirow{2}{*}{$\begin{array}{l}\text { KO mouse } \\
\text { Low blood pressure }\end{array}$} & \multirow{2}{*}{$\begin{array}{l}\text { Pharmacology } \\
\text { Inhibitors: CaCCinh-A01, } \\
\text { CaCCinh-B01, Niflumic } \\
\text { acid (NFA), and NPPB, } \\
\text { agonists: INS37217 }\end{array}$} & \multirow{2}{*}{$\begin{array}{l}\text { References } \\
\text { Chen et al., 2007; Yang } \\
\text { et al., 2008; Huang et al., } \\
\text { 2009; Stöhr et al., 2009; } \\
\text { Namkung et al., 2011; Jin } \\
\text { et al., 2013; Neureither } \\
\text { et al., } 2017\end{array}$} \\
\hline $\begin{array}{l}\text { TMEM16A } \\
\text { (Ano1) }\end{array}$ & $\begin{array}{l}\text { Epithelial tissue, smooth } \\
\text { muscle, interstitial cells of } \\
\text { Cajal, dorsal root ganglion } \\
\text { neurons }\end{array}$ & & & & & \\
\hline $\begin{array}{l}\text { TMEM16B } \\
\text { (Ano2) }\end{array}$ & $\begin{array}{l}\text { Brain (hippocampal and } \\
\text { thalamocortical neurons, } \\
\text { olfactory bulb, inferior olive, } \\
\text { Purkinje cells), retina, } \\
\text { muscle }\end{array}$ & $\begin{array}{l}\mathrm{Cl}_{\mathrm{Ca}} \text { channel, involved } \\
\text { in neuronal excitability, } \\
\text { olfactory and sensory } \\
\text { signal transduction and } \\
\text { smooth muscle } \\
\text { contraction }\end{array}$ & 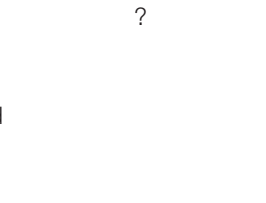 & $\begin{array}{l}\text { Impaired motor } \\
\text { behavior, partial } \\
\text { reduction of electrical } \\
\text { response to odorants, } \\
\text { normal olfaction }\end{array}$ & $\begin{array}{l}\text { Inhibitors: CaCCinh-A01, } \\
\text { CaCCinh-B01, Niflumic } \\
\text { acid (NFA) agonists: } \\
\text { INS37217 }\end{array}$ & $\begin{array}{l}\text { Stöhr et al., 2009; Billig } \\
\text { et al., 2011; Huang et al., } \\
\text { 2012; Dauner et al., 2013; } \\
\text { Zhang et al., 2015, 2017; } \\
\text { Ha et al., } 2016\end{array}$ \\
\hline $\begin{array}{l}\text { TMEM16C } \\
\text { (Ano3) }\end{array}$ & $\begin{array}{l}\text { Brain (dorsal root ganglion } \\
\text { cells), blood vessels, lung }\end{array}$ & $\begin{array}{l}\text { Phospholipid } \\
\text { scrambling, } \mathrm{K}_{\mathrm{Na}} \\
\text { channel regulator }\end{array}$ & $\begin{array}{l}\text { Craniocervical dystonia, } \\
\text { tremor, asthma }\end{array}$ & $\begin{array}{l}\text { Impaired endoplasmic } \\
\text { reticulum-dependent } \\
\mathrm{Ca}^{2+} \text { signaling }\end{array}$ & & $\begin{array}{l}\text { Charlesworth et al., 2012; } \\
\text { Huang et al., 2013a; Suzuki } \\
\text { et al., 2013; Miltgen et al., } \\
2016\end{array}$ \\
\hline $\begin{array}{l}\text { TMEM16E } \\
\text { (Ano5) }\end{array}$ & Muscle, bone, sperm & $\begin{array}{l}\text { Phospholipid } \\
\text { scrambling }\end{array}$ & $\begin{array}{l}\text { Muscular dystrophy, } \\
\text { gnathodiaphyseal } \\
\text { dysplasia }\end{array}$ & & & $\begin{array}{l}\text { Katoh, 2004; Tsutsumi et al., } \\
\text { 2004; Gyobu et al., } 2016\end{array}$ \\
\hline $\begin{array}{l}\text { TMEM16F } \\
\text { (Ano6) }\end{array}$ & $\begin{array}{l}\text { Blood vessels, endosomes, } \\
\text { brain? }\end{array}$ & $\begin{array}{l}\text { Phospholipid } \\
\text { scrambling, blood } \\
\text { coagulation, SCAN } \mathrm{Ca} \\
\text { channel, } \mathrm{Cl}_{\mathrm{Ca}} \text { channel, } \\
\text { involved in membrane } \\
\text { excitability }\end{array}$ & Scott syndrome & $\begin{array}{l}\text { Lysosomal storage } \\
\text { disease }\end{array}$ & & $\begin{array}{l}\text { Suzuki et al., 2010, 2013; } \\
\text { Yang et al., 2012; Grubb } \\
\text { et al., 2013; Shimizu et al., } \\
\text { 2013; Yu et al., } 2015\end{array}$ \\
\hline $\begin{array}{l}\text { TMEM16J } \\
\text { (Ano9) }\end{array}$ & $\begin{array}{l}\text { Epithelial cells, colonic } \\
\text { tissue }\end{array}$ & $\begin{array}{l}\text { Phospholipid } \\
\text { scrambling }\end{array}$ & Colorectal carcinoma & & & $\begin{array}{l}\text { Suzuki et al., 2013; Li et al., } \\
2015\end{array}$ \\
\hline $\begin{array}{l}\text { TMEM16K } \\
\text { (Ano10) }\end{array}$ & Epithelial cells, cerebellum? & $\begin{array}{l}\text { Intracellular protein } \\
\text { involved in intracellular } \\
\mathrm{Ca}^{2+} \text { signaling, } \\
\text { essential for apoptosis }\end{array}$ & $\begin{array}{l}\text { Autosomal recessive } \\
\text { cerebellar ataxia }\end{array}$ & & & $\begin{array}{l}\text { Vermeer et al., 2010; } \\
\text { Renaud et al., 2014; } \\
\text { Chamard et al., 2016; } \\
\text { Mišković et al., 2016; } \\
\text { Wanitchakool et al., } 2017\end{array}$ \\
\hline
\end{tabular}

by interacting with $\mathrm{Ca}^{2+}$ dependent $\mathrm{G}$ protein-coupled receptor signaling and compartmentalized $\mathrm{Ca}^{2+}$ (Jin et al., 2013; Courjaret and Machaca, 2014). Not surprisingly, also this affinity for the modulation by compartmentalized $\mathrm{Ca}^{2+}$ signals from internal stores is likely differentially modulated between anoctamin family members. The diverse functionalities, together with the differentially distributed expression among cell types (Table 2), reveal a picture where it seems likely that anoctamin members are expressed as a function of cell-specific $\mathrm{Ca}^{2+}$ dynamics.

Neurons are characterized by continuously changing local $\left[\mathrm{Ca}^{2+}\right]_{\mathrm{i}}$. Therefore, it is important to understand how these changes in intracellular milieu influence the responses of anoctamins. In hippocampal neurons, TMEM16B (Ano2) has been shown to affect action potential generation through a $\mathrm{Ca}^{2+}$ induced suppression of excitatory postsynaptic potentials in dendrites, which in turn lowers probability of action potential generation (Huang et al., 2012). In support of these data, a recent study performed in thalamic neurons demonstrated that Ano2 contributes to spike-frequency adaptation in thalamic neurons (Ha et al., 2016). In this study, knockdown of Ano2 reduces inter-spike interval lengths, resulting in a higher firing rate. The authors conclude that in the thalamus the main function of
Ano2 is to drive hyperpolarizing currents as a consequence of depolarization induced $\left[\mathrm{Ca}^{2+}\right]_{\mathrm{i}}$ increase. The difference between SK $\mathrm{K}_{\mathrm{Ca}}$ and $\mathrm{Ano} 2 \mathrm{Cl}_{\mathrm{Ca}}$ mediated hyperpolarization in thalamic cells was hypothesized to be due to different decay time kinetics between these channels, in that Ano2 has a longer decay time duration and thus stronger influence on spike-frequency adaptation. In addition, a behavioral relevance for the Ano2 mediated spike-frequency adaptation was revealed in thalamic neurons, as the mice that have Ano2 knockdown in the thalamus experience an increase in pain responses. From these data, the authors proposed that the Ano2-driven modulation of spike frequency adaptation may provide thalamic cells with the ability to suppress excessive thalamo-cortical transmission, which tunes the network sensitivity to sensory inputs that reach the thalamic complex.

In contrast to the previously discussed increase of excitability in thalamic neurons, a recent study on the role of Ano2 in IO cells reported that functional deletion of Ano2-channels resulted in decreased excitability of IO neurons (Zhang et al., 2017). In light of the typical IO activity pattern, which is dominated by oscillatory fluctuations of membrane potentials partially driven by $\mathrm{Ca}^{2+}$-currents, the impact of Ano2-mutations 
can be substantial. The so-called high threshold spikes are formed when high threshold $\mathrm{Ca}^{2+}$ channels are activated that allow for a large after-depolarization potential (ADP) upon which additional spikes (spikelets) can be detected (Llinás and Yarom, 1981a,b). In a study by Zhang et al. (2017) this ADP was shown to be prolonged in mouse mutants lacking Ano2. In addition, the IO cells showed prolonged AHP duration, which coincided with less spiking upon current injection. They hypothesized that the loss of the hyperpolarizing $\mathrm{Cl}_{\mathrm{Ca}}$ current in the Ano2 deficient mice leads to prolonged activation of $\mathrm{K}_{\mathrm{Ca}}$ SK channels and therefore to prolonged AHP duration, which in turn reduces the likelihood for action potential firing. The authors conclude that the role for Ano2 in IO cells seems to primarily function as a repolarizing current of the voltage gated $\mathrm{Ca}^{2+}$ currents and as such determines the ADP length to a rather large degree.

Other mechanisms by which anoctamins could potentially regulate neuronal excitability in the cerebellar system has been touched upon by recent studies in PCs, where $\mathrm{Cl}_{\mathrm{Ca}}$ channels were found to be involved in depolarization-induced depression of inhibition (Satoh et al., 2013; Zhang et al., 2015). Here, the authors reported Ano2-induced reduction of GABAergic transmission through an increase of postsynaptic $\left[\mathrm{Cl}^{-}\right]_{\mathrm{i}}$ that reduces the driving force for $\mathrm{Cl}^{-}$influx. As the $\mathrm{IO}$ is an integrated part of the olivo-cerebellar circuit, which has been shown to be critical for motor coordination and learning, Zhang et al. (2017) hypothesized that a less excitable IO due to the absence of Ano2 would lead to less input to PCs and as a consequence impaired motor learning. Zhang et al. (2017) investigated the behavioral consequences of Ano2 absence and found that Ano2 knockout mice had significant deficits in their motor learning performance during classical eyeblink conditioning, a cerebellar dependent task where a conditioned stimulus (light/sound) predicts the arrival of an unconditioned stimulus (air puff). However, the idea that a cerebellar related dysfunction in behavior can solely be due to IO expression of Ano2 has recently been put to question (Neureither et al., 2017). In this study, Neureither et al. (2017) proposed the previously mentioned depolarizationinduced depression of inhibition in PCs to be the main cause for the motor deficits found in their Ano2 knockout model. In this respect, it is important to emphasize that even though the Ano2 protein is abundantly expressed in the IO, there is also evidence for its expression in other brain areas involved in motor function, including the thalamus (Table 2). Further research will have to be conducted to determine whether the dysfunctional cerebellar related motor behaviors described in these studies can be reproduced in the conditional removal of Ano 2 in the IO and/or PCs.

\section{PH-SENSITIVE $\mathrm{CL}^{-}$CHANNELS AND TRANSPORTERS}

Acid-base regulation is a homeostatic mechanism, which is crucial for cell survival and function in all tissues. All vertebrates generate significant amount of acid via metabolism. To buffer the metabolic acid load, increasing the concentration of systemic bicarbonate $\left(\mathrm{HCO}_{3}^{-}\right)$aids the cell's capacity to extrude acid $\left(\mathrm{H}^{+}\right)$.
The transmembrane transport mechanisms for $\mathrm{pH}$ regulation include $\mathrm{Cl}^{-} / \mathrm{HCO}_{3}^{-}$exchangers, $\mathrm{Na}^{+} / \mathrm{H}^{+}$exchangers, and $\mathrm{Na}^{+} / \mathrm{HCO}_{3}^{-}$cotransporters. These transporters are expressed in all cell types, including neurons and glia and are localized at the plasma membrane and membranes of the intracellular organelles (Alka and Casey, 2014). Studies on hippocampal neurons have reported an association between intracellular $\mathrm{pH}$ changes with neuronal excitability, in a way that a rise in the intracellular $\mathrm{pH}$ leads to increased neuronal excitability, while a fall in $\mathrm{pH}$ has the opposite effect (Balestrino and Somjen, 1988; Tombaugh and Somjen, 1996). It has been suggested that $\mathrm{pH}$-induced neuronal activity may be related to the activation of NMDA receptors, which are highly $\mathrm{pH}$ sensitive and show increased open probability at alkaline pH (Tang et al., 1990; Traynelis and Cull-Candy, 1990; Majumdar and Bevensee, 2010). Here, we emphasize the expression, localization, and functional significance of $\mathrm{Cl}^{-} / \mathrm{HCO}_{3}^{-}$exchangers of the SLC4 and SLC26 families, which are involved in regulation of both intracellular $\mathrm{pH}$ and $\left[\mathrm{Cl}^{-}\right]_{\mathrm{i}}$.

\subsection{SLC4 Family}

One of the well-known families of $\mathrm{HCO}_{3}^{-}$transporters is the SLC4 family of $\mathrm{Cl}^{-} / \mathrm{HCO}_{3}^{-}$exchangers, which is widely expressed in the body. This family contains 10 members (SLC4A1-5 and A7-11), with some mediating $\mathrm{Na}^{+}$-independent $\mathrm{Cl}^{-} / \mathrm{HCO}_{3}^{-}$ exchange (Anion Exchanger 1-3 or AE1-AE3) and some isoforms facilitating $\mathrm{Na}^{+}$-dependent $\mathrm{Cl}^{-} / \mathrm{HCO}_{3}^{-}$exchange (NCBE and NDCBE). AE transporters mediate $\mathrm{HCO}_{3}^{-}$extrusion while transporting $\mathrm{Cl}^{-}$inside the cell. In contrast, NCBE and NDCBE transport $\mathrm{HCO}_{3}^{-}$inside and $\mathrm{Cl}^{-}$outside of the cell (Figure 2). The $\mathrm{Cl}^{-} / \mathrm{HCO}_{3}^{-}$exchangers have been shown to be important for baseline intracellular $\mathrm{pH}$ regulation, as well as facilitation of recovery after $\mathrm{pH}$ modifications (Hentschke et al., 2006; Jacobs et al., 2008). Three members of the SLC4 family are expressed in the olivocerebellar system, including SLC4A3 (AE3), SLC4A8 (NDCBE), and SLC4A10 (NCBE) (Chen et al., 2008; Burette et al., 2012). Here we review the literature on AE3 and NCBE, which have been studied for their functional roles.

\section{SLC4A3 (AE3)}

AE3 is an anion exchanger expressed in a wide variety of cells, which include for example particular types of excitable cells in the retina, heart, and brain (Alka and Casey, 2014). Similar to NKCC1, AE3 is considered as one of the main $\mathrm{Cl}^{-}$accumulators in neurons by mediating the electroneutral exchange of one $\mathrm{Cl}^{-}$while extruding one $\mathrm{HCO}_{3}^{-}$(Figure 2). In mammals, there are two variants of the $S L C 4 A 3$ gene product: bAE3, which is abundant in the brain and retina, and cAE3, which is highly expressed in the cardiac tissue (Hentschke et al., 2006; Romero et al., 2013). bAE3 protein has been found in the hippocampus, cerebral cortex, cerebellum, and brainstem (Romero et al., 2013). In hippocampal pyramidal cells elevated $\mathrm{pH}$ levels activate bAE3, which leads to $\mathrm{HCO}_{3}^{-}$extrusion, a function essential for recovery of intracellular alkalosis (Hentschke et al., 2006). There are reports on single nucleotide polymorphisms that occur in SLC4A3 gene and are predicted to impact the protein sequence of bAE3 at the extracellular loop and that may promote a higher 


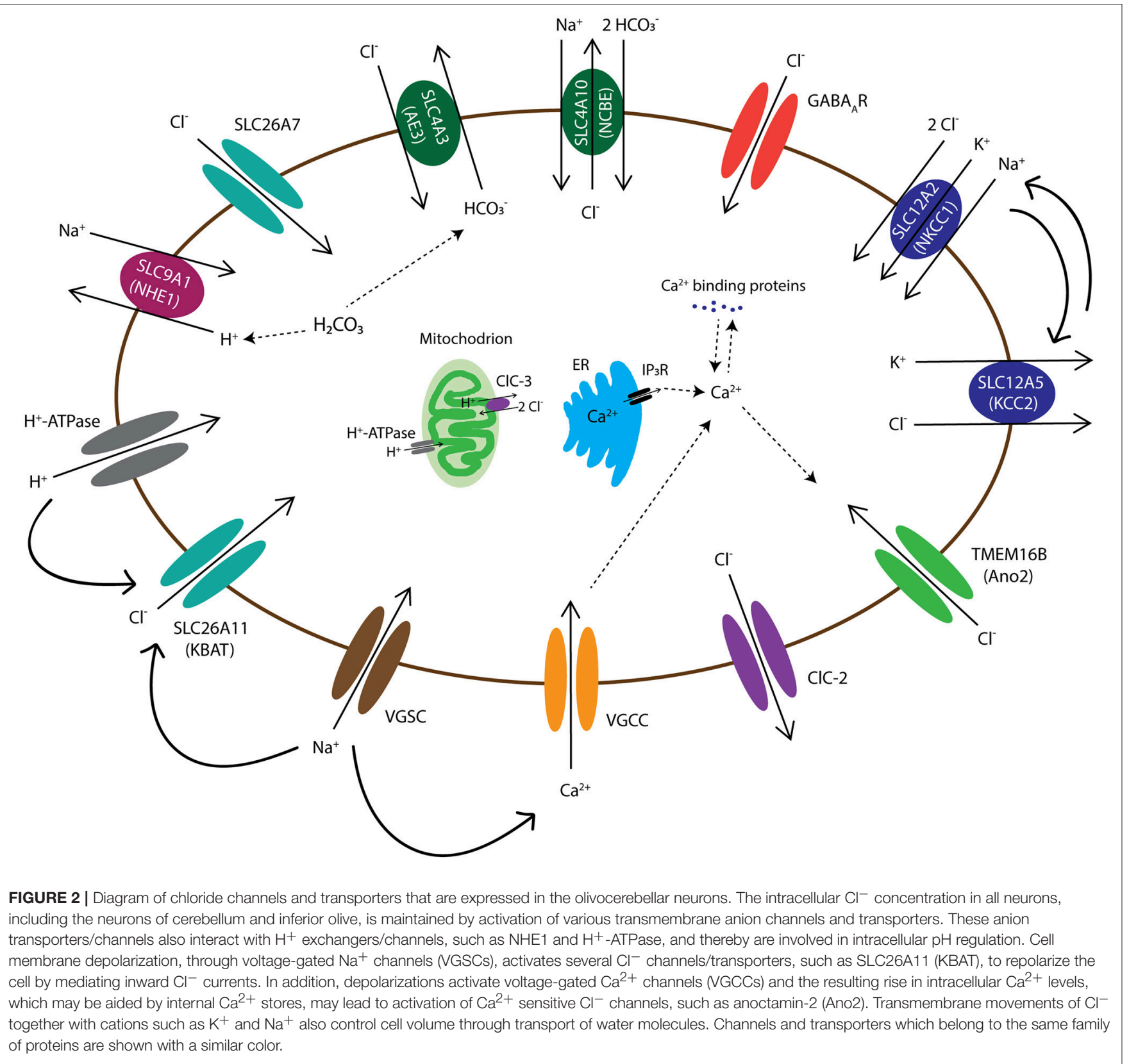

sensitivity to idiopathic generalized epilepsy (Sander et al., 2002). While AE3 knockout mice appeared to be normal, they were affected by a lower seizure threshold and higher mortality rates after exposure to bicuculline, pentylenetetrazole, or pilocarpine (Hentschke et al., 2006). It is hypothesized that the increased seizure susceptibility of AE3 knockout mice is due to increased $\left[\mathrm{HCO}_{3}^{-}\right]_{\mathrm{i}}$ in hippocampal pyramidal neurons (Hentschke et al., 2006). Given that $\mathrm{GABA}_{\mathrm{A}}$ Rs are also permeable to $\mathrm{HCO}_{3}^{-}$, it may be that the observed phenotype of AE3 knockout mice, i.e., reduced GABAergic inhibition, is due to an increased $\left[\mathrm{HCO}_{3}^{-}\right]_{\mathrm{i}}$ (Hentschke et al., 2006). However, a lack of AE3 exchanger should also result in decreased $\left[\mathrm{Cl}^{-}\right]_{\mathrm{i}}$ and enhanced GABAergic inhibition. To identify the cellular mechanisms underlying the involvement of AE3 in neuronal excitability in future studies, one may have to combine $\mathrm{Cl}^{-}$and $\mathrm{pH}$ measurements in neurons lacking AE3, as well as perform RNA-seq and DNA microarray to study the possibility of genetic compensations.

\section{SLC4A10 (NCBE)}

$\mathrm{NCBE}$ functions as a $\mathrm{Na}^{+}$-dependent $\mathrm{Cl}^{-} / \mathrm{HCO}_{3}^{-}$exchanger. It is expressed in the olfactory bulb, cerebral cortex, brain stem, spinal cord, and cerebellum (Jacobs et al., 2008). In the cerebellum, it is densely expressed in PCs (Liu et al., 2011; Romero et al., 2013). Similar to SLC4A8 (NDCBE), NCBE may mediate the inward transport of $\mathrm{Na}^{+}$and $\mathrm{HCO}_{3}^{-}$in exchange for intracellular $\mathrm{Cl}^{-}$(Figure 2). Various studies have proposed that modest 
levels of intracellular acidification can lead to termination of seizure-related activities (Chesler and Kaila, 1992; Zhan et al., 1998; Tong and Chesler, 1999; Jacobs et al., 2008). Using a global NCBE knockout mouse, Jacobs and colleagues found a significant increase in seizure threshold, supporting the impact of reduced $\mathrm{HCO}_{3}^{-}$uptake and prolonged intracellular acidosis on seizure generating processes (Jacobs et al., 2008). NCBE knockout mice showed normal locomotor activity, as well as motor and spatial learning (Jacobs et al., 2008). MRI analysis of knockout mice indicated a significant reduction in the volume of brain ventricles compared to littermate controls. One of the reasons for collapsed ventricles could be an increase in intracranial pressure due to water accumulation in the brain parenchyma (Jacobs et al., 2008). However, NCBE knockout mice did not show any other anatomical signs of increased intracranial pressure (Jacobs et al., 2008). Jacob and colleagues concluded that NCBE can be considered as a new target for treatment of epilepsy.

How the $\left[\mathrm{Cl}^{-}\right]_{\mathrm{i}}$ and the $\mathrm{pH}$ regulation by $\mathrm{Cl}^{-} / \mathrm{HCO}_{3}^{-}$ transporters interact in the olivocerebellar system remains to be investigated. However, studies on other channels and transporters sensitive to $\mathrm{pH}$ levels (e.g., Acid-Sensing Ion Channels or ASICs) have indicated a modulatory role for $\mathrm{pH}$ in neurotransmission and neuronal plasticity via influencing the activity of ionotropic and metabotropic glutamate receptors in both cerebellar and extracerebellar neurons (Allen and Attwell, 2002; Jovov et al., 2003). Tissue distributions and functions of SLC4 isoforms with $\mathrm{Cl}^{-} / \mathrm{HCO}_{3}^{-}$activity are summarized in Table 3.

\subsection{SLC26 Family}

The SLC26 family of anion exchangers consists of 10 members (SLC26A1-A11). Each SLC26 isoform has different modes of ion transport activities, including the exchange of $\mathrm{Cl}^{-}$for various other molecules (bicarbonate, hydroxyl, sulfate, formate, iodide, or oxalate) and the formation of $\mathrm{Cl}^{-}$channels (Rahmati et al., 2013; Soleimani, 2013). Mutations in human SLC26 genes can cause several autosomal recessive diseases, such as chondrodysplasias (by mutations in A2), chloride diarrhea (A3), and deafness and enlargement of the vestibular aqueduct in the Pendred syndrome (A4) (Hästbacka et al., 1994; Everett et al., 1997). Several mouse models of SLC26-family members have confirmed the wide range of tissue specific deficits (Table 4). Although studies have demonstrated the important roles of SLC26 family in different tissues, there are only few reports describing their expression patterns and functions in the brain. Here, we review the most recent findings for SLC26A7 and SLC26A11, which have been studied by utilizing knock-out mouse models.

\section{SLC26A7}

SLC26A7 functions as a $\mathrm{Cl}^{-}$channel, which is regulated by intracellular $\mathrm{pH}$ (Kim et al., 2005). It can also operate as $\mathrm{Cl}^{-} / \mathrm{HCO}_{3}^{-}$exchanger, which plays a role in cell volume regulation during hypertonicity (Petrovic et al., 2003, 2004; Soleimani, 2013). SLC26A7-null mice show deficits in acid secretion in both kidney and stomach (Soleimani, 2013). In the brain, SLC26A7 is expressed in several regions including hippocampus and cerebellum, with the highest expression level in cerebellar PCs (Rahmati, 2015). In PCs SLC26A7 is densely expressed in both soma and dendrites. At the subcellular level, it is expressed both in cell membrane and intracellular compartments, but the function of SLC26A7 in cerebellar neurons remains to be elucidated. The locomotor activity of global SLC26A7 knockout mice is altered (smaller step size) compared to their wild type controls (Rahmati, 2015). One potential cause for this behavioral abnormality could be that the lack of SLC26A7 disrupts $\left[\mathrm{Cl}^{-}\right]_{\mathrm{i}}$ and/or intracellular $\mathrm{pH}$, which in principle could disrupt cerebellar activity patterns. Future experiments should address this hypothetical cascade.

\section{SLC26A11 (KBAT)}

SLC26A11, also referred to as the "kidney brain anion transporter" (KBAT) due to its high expression levels in the kidney and brain, has been identified to operate as a $\mathrm{Cl}^{-} / \mathrm{HCO}_{3}^{-}$ exchanger, $\mathrm{Cl}^{-} / \mathrm{SO}_{4}^{2-}$ exchanger, or $\mathrm{Cl}^{-}$channel (Xu et al., 2011; Rahmati et al., 2013; Soleimani, 2013). KBAT is expressed in

TABLE 3 | SLC4 family of anion transporters.

\begin{tabular}{|c|c|c|c|c|c|c|}
\hline SLC4 & Expression & Function & Human disease & KO mouse & Pharmacology & References \\
\hline $\begin{array}{l}\text { SLC4A1 } \\
\text { (AE1) }\end{array}$ & $\begin{array}{l}\text { Erythrocytes, kidney, } \\
\text { heart, colon }\end{array}$ & $\mathrm{Cl}^{-} / \mathrm{HCO}_{3}^{-}$exchanger & $\begin{array}{l}\text { Hemolytic anemia, } \\
\text { distal renal tubular } \\
\text { acidosis }\end{array}$ & & Inhibitor: DIDS & $\begin{array}{l}\text { Bruce et al., 1997; Jarolim et al., } \\
\text { 1998; Karet et al., 1998; Shayakul } \\
\text { and Alper, 2004; Stehberger } \\
\text { et al., 2007; Romero et al., } 2013\end{array}$ \\
\hline $\begin{array}{l}\text { SLC4A2 } \\
\text { (AE2) }\end{array}$ & Most epithelial cells & $\mathrm{Cl}^{-} / \mathrm{HCO}_{3}^{-}$exchanger & Osteopetrosis & & Inhibitor: DIDS & $\begin{array}{l}\text { Gawenis et al., 2004; Romero } \\
\text { et al., } 2013\end{array}$ \\
\hline $\begin{array}{l}\text { SLC4A3 } \\
\text { (AE3) }\end{array}$ & $\begin{array}{l}\text { Brain, kidney, Gl tract, } \\
\text { smooth muscle and } \\
\text { heart }\end{array}$ & $\mathrm{Cl}^{-} / \mathrm{HCO}_{3}^{-}$exchanger & Epilepsy, blindness & Lower seizure threshold & Inhibitor: DIDS & $\begin{array}{l}\text { Sander et al., 2002; Hentschke } \\
\text { et al., 2006; Romero et al., 2013; } \\
\text { Ruffin et al., } 2014\end{array}$ \\
\hline $\begin{array}{l}\text { SLC4A8 } \\
\text { (NDCBE) }\end{array}$ & $\begin{array}{l}\text { Brain, kidney, testes } \\
\text { and ovary }\end{array}$ & $\begin{array}{l}\mathrm{Na}^{+}-\text {dependent } \\
\mathrm{Cl}^{-} / \mathrm{HCO}_{3}^{-} \text {exchanger, } \\
\text { acid extruder }\end{array}$ & $?$ & & Inhibitor: DIDS & $\begin{array}{l}\text { Chen et al., 2008; Burette et al., } \\
2012\end{array}$ \\
\hline $\begin{array}{l}\text { SLC4A10 } \\
\text { (NCBE) }\end{array}$ & Brain & $\begin{array}{l}\mathrm{pH} \text { regulation (acid } \\
\text { extrusion) }\end{array}$ & $?$ & $\begin{array}{l}\text { Higher seizure threshold, } \\
\text { volume reduction of brain } \\
\text { ventricles }\end{array}$ & Inhibitor: DIDS & $\begin{array}{l}\text { Chen et al., 2008; Jacobs et al., } \\
\text { 2008; Liu et al., 2011; Romero } \\
\text { et al., } 2013\end{array}$ \\
\hline
\end{tabular}


TABLE 4 | SLC26 family of anion transporters.

\begin{tabular}{|c|c|c|c|c|c|c|}
\hline SLC26 & Expression & Function & Human disease & KO mouse & Pharmacology & References \\
\hline $\begin{array}{l}\text { SLC26A1 } \\
\text { (SAT1) }\end{array}$ & $\begin{array}{l}\text { Kidney, Gl tract, liver, } \\
\text { lung }\end{array}$ & $\begin{array}{l}\mathrm{SO}_{4}^{2-} / \mathrm{Ox}^{2-} \text { exchanger, } \\
\mathrm{SO}_{4}^{2-} / \mathrm{HCO}_{3}^{-} \text {exchanger }\end{array}$ & & $\begin{array}{l}\text { Oxalate urolithiasis, } \\
\text { nephrocalcinosis, } \\
\text { urinary sulfate wasting, } \\
\text { hepatotoxicity }\end{array}$ & & $\begin{array}{l}\text { Xie et al., 2002; Soleimani and } \\
\text { Xu, 2006; Soleimani, } 2013\end{array}$ \\
\hline $\begin{array}{l}\text { SLC26A2 } \\
\text { (DTDST) }\end{array}$ & $\begin{array}{l}\text { Kidney, Gl tract, } \\
\text { chondrocytes }\end{array}$ & $\begin{array}{l}\mathrm{Cl}^{-} / \mathrm{SO}_{4}^{2-} \text { transporter, } \\
\mathrm{SO}_{4}^{2-} / \mathrm{Ox}^{2-} \text { exchanger }\end{array}$ & Diastrophic dysplasia & Diastrophic dysplasia & & $\begin{array}{l}\text { Hästbacka et al., 1994; } \\
\text { Soleimani and Xu, } 2006 \\
\text { Soleimani, } 2013\end{array}$ \\
\hline $\begin{array}{l}\text { SLC26A3 } \\
\text { (DRA) }\end{array}$ & $\begin{array}{l}\text { Gl tract, epididymis, } \\
\text { enterocytes }\end{array}$ & $\mathrm{Cl}^{-} / \mathrm{HCO}_{3}^{-}$exchanger & $\begin{array}{l}\text { Congenital chloride } \\
\text { diarrhea }\end{array}$ & $\begin{array}{l}\text { Congenital chloride } \\
\text { diarrhea }\end{array}$ & & $\begin{array}{l}\text { Höglund et al., 1996; Soleimani, } \\
2013\end{array}$ \\
\hline $\begin{array}{l}\text { SLC26A4 } \\
\text { (pendrin) }\end{array}$ & $\begin{array}{l}\text { Kidney, inner ear, } \\
\text { thyrocytes, lung }\end{array}$ & $\mathrm{Cl}^{-} / \mathrm{HCO}_{3}^{-}$exchanger & Pendred syndrome & $\begin{array}{l}\text { Deafness, enlargement } \\
\text { of the vestibular } \\
\text { aqueduct }\end{array}$ & & $\begin{array}{l}\text { Reardon and Trembath, 1996; } \\
\text { Everett et al., 1997; Kopp, } \\
\text { 2000; Soleimani, } 2013\end{array}$ \\
\hline $\begin{array}{l}\text { SLC26A5 } \\
\text { (prestin) }\end{array}$ & Cochlear hair cells & $\mathrm{Cl}^{-} / \mathrm{HCO}_{3}^{-}$exchanger & Deafness & Deafness & & $\begin{array}{l}\text { Liberman et al., 2002; Liu et al., } \\
\text { 2003; Cheatham et al., 2004; } \\
\text { Alper and Sharma, } 2013\end{array}$ \\
\hline $\begin{array}{l}\text { SLC26A6 } \\
\text { (PAT1) }\end{array}$ & $\begin{array}{l}\text { Gl tract, kidney, } \\
\text { cardiac myocytes }\end{array}$ & $\begin{array}{l}\mathrm{Cl}^{-} / \mathrm{HCO}_{3}^{-} \text {exchanger, } \\
\mathrm{Cl}^{-} / \mathrm{Ox}^{2-} \text { exchanger, } \\
\mathrm{Cl}^{-} / \text {formate exchanger }\end{array}$ & $?$ & & & $\begin{array}{l}\text { Soleimani, 2001; Mount and } \\
\text { Romero, 2004; Alper et al., } \\
\text { 2006; Aronson, } 2006\end{array}$ \\
\hline SLC26A7 & $\begin{array}{l}\text { Brain, kidney, Gl } \\
\text { tract, lung }\end{array}$ & $\begin{array}{l}\mathrm{Cl}^{-} / \mathrm{HCO}_{3}^{-} \text {exchanger, } \\
\mathrm{Cl}^{-} \text {channel }\end{array}$ & $?$ & $\begin{array}{l}\text { Locomotor impairment, } \\
\text { gastric } \\
\text { hypochlorhydria, distal } \\
\text { renal tubular acidosis }\end{array}$ & Inhibitor: DIDS & $\begin{array}{l}\text { Kim et al., 2005; Xu et al., 2006; } \\
\text { Soleimani, 2013; Rahmati, } 2015\end{array}$ \\
\hline SLC26A8 & $\begin{array}{l}\text { Male germ cells, } \\
\text { kidney }\end{array}$ & $\begin{array}{l}\mathrm{Cl}^{-} / \mathrm{Ox}^{2-} \text { exchanger, } \\
\mathrm{Cl}^{-} / \mathrm{SO}_{4}^{2-} \text { exchanger }\end{array}$ & $?$ & Male infertility & & $\begin{array}{l}\text { Touré et al., 2001; Lohi et al., } \\
\text { 2002; Soleimani and Xu, } 2006\end{array}$ \\
\hline SLC26A9 & $\begin{array}{l}\text { Stomach, lung, } \\
\text { lower levels in kidney }\end{array}$ & $\begin{array}{l}\mathrm{Cl}^{-} / \mathrm{HCO}_{3}^{-} \text {exchanger, } \\
\mathrm{Cl}^{-} \text {channel, } \mathrm{Na}^{+} / \mathrm{Cl}^{-} \\
\text {cotransporter }\end{array}$ & $?$ & Hypertension & & $\begin{array}{l}\text { Xu et al., 2005; Amlal et al., } \\
\text { 2013; Soleimani, } 2013\end{array}$ \\
\hline $\begin{array}{l}\text { SLC26A11 } \\
\text { (KBAT) }\end{array}$ & $\begin{array}{l}\text { Brain, kidney, Gl } \\
\text { tract }\end{array}$ & $\begin{array}{l}\mathrm{Cl}^{-} \text {channel, } \mathrm{Cl}^{-} / \mathrm{HCO}_{3}^{-} \\
\text {exchanger, volume } \\
\text { control, pH regulation }\end{array}$ & $?$ & Locomotor impairment & $\begin{array}{l}\text { Inhibitor: GlyH-101, } \\
\text { CFTRinh, DIDS } \\
\text { (partial inhibition) }\end{array}$ & $\begin{array}{l}\text { Vincourt et al., 2003; Rahmati } \\
\text { et al., 2013, 2016; Rungta } \\
\text { et al., } 2015\end{array}$ \\
\hline
\end{tabular}

different parts of the brain with various intensities, including cerebral cortex, hippocampus, olfactory bulb, and cerebellum. Cerebellar PCs show prominent expression of KBAT (Rahmati et al., 2013). At the subcellular level, KBAT was identified both in the cytoplasm and at the plasma membrane of PCs. Studies on HEK293 cells showed that KBAT can operate as a $\mathrm{Cl}^{-}$channel that functionally interacts with $\mathrm{H}^{+}$-ATPase. Transfection of cells with KBAT stimulated acid transport via $\mathrm{H}^{+}$-ATPase and the cells with KBAT expression showed a more robust recovery from intracellular acidosis relative to mock transfected cells (Rahmati et al., 2013).

Studies on hippocampal and cortical pyramidal cells have reported the direct involvement of KBAT in cell death after cytotoxic edema (Rungta et al., 2015). Cytotoxic edema is one of the hallmark features of TBI and starts with an excessive $\mathrm{Na}^{+}$entry that depolarizes the membrane (Rungta et al., 2015). These processes activate the $\mathrm{Cl}^{-}$influx through KBAT channels, which in turn causes cell swelling and cell death (Rungta et al., 2015). Inhibition of KBAT by utilizing siRNAmediated knockdown of KBAT significantly prevents $\mathrm{Cl}^{-}$influx and cell death after cytotoxic edema (Rungta et al., 2015). Rungta and colleagues showed that in their mouse model of TBI the recovery mechanism after increased cell volume was independent of NKCC1 and KCC2 activity as $100 \mu \mathrm{M}$ bumetanide did not significantly affect the volume of swollen neurons.

In the cerebellum, recent data support the role of KBAT in intracellular $\mathrm{Cl}^{-}$accumulation. Selective deletion of KBAT from PCs causes a significant reduction in $\left[\mathrm{Cl}^{-}\right]_{\mathrm{i}}$ and a more negative $\mathrm{E}_{\mathrm{Cl}}$. At the behavioral level, lack of KBAT in PCs causes deficits in locomotor activity (Rahmati et al., 2016). Considering the role of KBAT in neuronal $\mathrm{Cl}^{-}$transport, as well as its involvement in cell swelling after cytotoxic edema, KBAT may provide a novel target for designing new therapeutic strategies for neurological conditions such as TBI.

\section{CATION-CHLORIDE CO-TRANSPORTERS (SLC12 FAMILY)}

The SLC12 family has been studied in greater detail compared to other $\mathrm{Cl}^{-}$transporters. It is known as the cation-chloride cotransporter gene family (CCC), which contains 9 members (SLC12A1- SLC12A9). SLC12 isoforms (except A8 and A9) transport $\mathrm{Cl}^{-}$, together with $\mathrm{Na}^{+}$and/or $\mathrm{K}^{+}$in an electroneutral manner (Hebert et al., 2004). In neurons studies have mostly focused on the roles of SLC12A2 (NKCC1) and SLC12A5 (KCC2) 
TABLE 5 | SLC12 family of cation-chloride cotransporters.

\begin{tabular}{|c|c|c|c|c|c|c|}
\hline SLC12 & Expression & Function & Human disease & KO mouse & Pharmacology & References \\
\hline $\begin{array}{l}\text { SLC12A1 } \\
\text { (NKCC2) }\end{array}$ & $\begin{array}{l}\text { Kidney, gastrointestinal } \\
\text { tract, pancreatic } \beta \text {-cells, } \\
\text { induced in hypothalamo- } \\
\text { neurohypophyseal } \\
\text { system (HNS) by osmotic } \\
\text { stress }\end{array}$ & $\begin{array}{l}\mathrm{Na}^{+} / \mathrm{K}^{+} / \mathrm{Cl}^{-} \text {cotransporter } \\
\text { involved in salt } \\
\text { reabsorption }\end{array}$ & Bartter's syndrome type I & $\begin{array}{l}\text { Sever hypotension, } \\
\text { hypokalemia, hypercalcinuria, } \\
\text { metabolic alkalosis }\end{array}$ & $\begin{array}{l}\text { Inhibitors: } \\
\text { bumetanide } \\
(10 \mu \mathrm{M}) \text {, furosemide }\end{array}$ & $\begin{array}{l}\text { Rocha and Kokko, 1973; } \\
\text { Simon et al., 1996; Xue et al., } \\
\text { 2009; Alshahrani and Di } \\
\text { Fulvio, 2012b; Castrop and } \\
\text { Schießl, 2014; Konopacka } \\
\text { et al., } 2015\end{array}$ \\
\hline $\begin{array}{l}\text { SLC12A2 } \\
\text { (NKCC1) }\end{array}$ & Broad & $\begin{array}{l}\mathrm{Na}^{+} / \mathrm{K}^{+} / \mathrm{Cl}^{-} \text {cotransporter } \\
\text { involved in regulation of } \\
{\left[\mathrm{Cl}^{-}\right] \text {i and cell volume, }} \\
\text { regulation of } E_{\text {GABA }} \text { in } \\
\text { neurons }\end{array}$ & $\begin{array}{l}\text { Dehydration, vomiting, } \\
\text { dilated cardiomyopathy, } \\
\text { respiratory weakness, } \\
\text { pancreatic insufficiency, } \\
\text { missense mutation in a } \\
\text { group of patients with } \\
\text { schizophrenia, } \\
\text { seizure-like episodes }\end{array}$ & $\begin{array}{l}\text { Impaired sensory perception, } \\
\text { deafness, infertility, } \\
\text { hypotension, reduction of } \\
\text { saliva production, normal } \\
\text { intestinal absorption, } \\
\text { enhanced insulin secretion } \\
\text { and improved glucose } \\
\text { tolerance }\end{array}$ & $\begin{array}{l}\text { Inhibitors: } \\
\text { bumetanide } \\
(10 \mu \mathrm{M}) \text {, furosemide }\end{array}$ & $\begin{array}{l}\text { Cherubini et al., 1991; Ben-Ari } \\
\text { et al., 1997; Delpire et al., } \\
\text { 1999, 2016; Dixon et al., } \\
\text { 1999; Evans et al., 2000; } \\
\text { Grubb et al., 2000; Pace } \\
\text { et al., 2000; Sung et al., 2000; } \\
\text { Alshahrani and Di Fulvio, } \\
\text { 2012a; Flores et al., 2016; } \\
\text { Merner et al., } 2016\end{array}$ \\
\hline $\begin{array}{l}\text { SLC12A3 } \\
\text { (NCC) }\end{array}$ & $\begin{array}{l}\text { Kidney, peripheral blood } \\
\text { mononuclear cells, colon, } \\
\text { spleen, placenta, small } \\
\text { intestine, prostate }\end{array}$ & $\begin{array}{l}\mathrm{Na}^{+} / \mathrm{Cl}^{-} \text {cotransporter } \\
\text { involved in salt } \\
\text { reabsorption }\end{array}$ & Gitelman syndrome & $\begin{array}{l}\text { Hypotension, hypokalemia, } \\
\text { hypercalcinuria, } \\
\text { hypomagnesemia }\end{array}$ & Inhibitor: thiazide & $\begin{array}{l}\text { Costanzo, 1985; Ellison et al., } \\
\text { 1987; Chang et al., 1996; } \\
\text { Abuladze et al., 1998; Arroyo } \\
\text { et al., } 2013\end{array}$ \\
\hline $\begin{array}{l}\text { SLC12A4 } \\
\text { (KCC1) }\end{array}$ & Broad & $\begin{array}{l}\mathrm{K}^{+} / \mathrm{Cl}^{-} \text {cotransporter, } \\
\text { involved in cell volume } \\
\text { regulation }\end{array}$ & $?$ & No phenotype is reported & Inhibitor: furosemide & $\begin{array}{l}\text { Kanaka et al., 2001; Mikawa } \\
\text { et al., 2002; Arroyo et al., } \\
2013\end{array}$ \\
\hline $\begin{array}{l}\text { SLC12A5 } \\
\text { (KCC2) }\end{array}$ & $\begin{array}{l}\text { Brain, pancreatic } \beta \text {-cells, } \\
\text { adrenal chromaffin cells, } \\
\text { cancer cells }\end{array}$ & $\begin{array}{l}\mathrm{K}^{+} / \mathrm{Cl}^{-} \text {cotransporter, } \\
\text { involved in regulation of } \\
{\left[\mathrm{Cl}^{-}\right]_{\mathrm{i}} \text {, neuronal excitability }} \\
\text { and cell volume, } \\
\text { modulation of insulin } \\
\text { secretion }\end{array}$ & $\begin{array}{l}\text { Epilepsy, tumor } \\
\text { invasion/metastasis }\end{array}$ & $\begin{array}{l}\text { Complete } \mathrm{KO} \text { : death } \\
\text { conditional } \mathrm{KO} \text { : increased } \\
{\left[\mathrm{Cl}^{-}\right]_{i} \text {, positive shift of } \mathrm{E}_{\mathrm{GABA}} \text {, }} \\
\text { neuronal hyperexcitability, } \\
\text { impaired motor performance, } \\
\text { and motor learning }\end{array}$ & $\begin{array}{l}\text { Inhibitors: } \\
\text { bumetanide } \\
(100 \mu \mathrm{M}) \text {, } \\
\text { furosemide, } \\
\text { VU0463271, VU } \\
\text { 0240551, ML077 } \\
\text { activator: CLP257 }\end{array}$ & $\begin{array}{l}\text { Williams et al., 1999; Ben-Ari, } \\
\text { 2002; Song et al., 2002; Xie } \\
\text { et al., 2003; Wei et al., 2011; } \\
\text { Seja et al., 2012; Arroyo et al., } \\
\text { 2013; Lavertu et al., 2013; Yu } \\
\text { et al., 2014; Kahle et al., 2016; } \\
\text { Kursan et al., 2017; Liu et al., } \\
\text { 2017; Moore et al., } 2017\end{array}$ \\
\hline $\begin{array}{l}\text { SLC12A6 } \\
\text { (KCC3) }\end{array}$ & Broad & $\begin{array}{l}\mathrm{K}^{+} / \mathrm{Cl}^{-} \text {cotransporter, } \\
\text { involved in cell volume } \\
\text { regulation }\end{array}$ & $\begin{array}{l}\text { Andermann syndrome } \\
\text { (ACCPN), epilepsy? }\end{array}$ & $\begin{array}{l}\text { Hypertension, progressive } \\
\text { neurodegeneration, reduced } \\
\text { seizure threshold, deafness }\end{array}$ & Inhibitor: furosemide & $\begin{array}{l}\text { Pearson et al., 2001; Hebert } \\
\text { et al., 2004; Seja et al., } 2012\end{array}$ \\
\hline
\end{tabular}

in regulation of inhibition through $\mathrm{GABA}_{\mathrm{A}} \mathrm{R}$ activity (Takayama and Inoue, 2007; Seja et al., 2012; Kawakita et al., 2013). Earlier studies reported differential expression patterns for NKCC1 and KCC2 during development with higher NKCC1 expressions in immature brain and increased KCC2 levels in the adult brain (Plotkin et al., 1997; Lu et al., 1999; Rivera et al., 1999; Stein et al., 2004; Dzhala et al., 2005). According to these studies, the protein expression ratio of $\mathrm{NKCC} 1$ to $\mathrm{KCC} 2$ can explain the differences in $\left[\mathrm{Cl}^{-}\right]_{\mathrm{i}}$ and GABAergic signaling during development. However, recent findings suggest that NKCC1 and KCC2 cannot always explain the levels of $\left[\mathrm{Cl}^{-}\right]_{\mathrm{i}}$ (Glykys et al., 2014, 2017; Sedmak et al., 2016), because their activities as ion transporters are controlled by post-translational modifications, such as protein phosphorylation (Rinehart et al., 2009; Friedel et al., 2015).

SLC12 isoforms in the brain are also involved in cell volume regulation. Transport of $\mathrm{Cl}^{-}$and cations through some CCCs is accompanied by the movement of water which can lead to neuronal swelling or shrinkage, unless other volumeregulated $\mathrm{Cl}^{-}$transporters and channels are activated (MacAulay et al., 2004; Zeuthen, 2010; Jourdain et al., 2011; Glykys et al., 2017). Mutations in genes encoding for CCC isoforms result in various brain pathologies, like seizures, cerebral edema, neurodevelopmental deficits, and neuropathic pain. Pharmacological inhibitors of CCC functioning, like bumetanide and furosemide, which are well-known as loop diuretics, inhibit the CCCs both in vitro and in vivo (Dzhala et al., 2005, 2008). In low concentrations $(2-10 \mu \mathrm{M})$ bumetanide specifically inhibits
NKCC1 and exerts antiepileptic effects in human neonates (Kahle et al., 2009). In the cerebellum, four members of SLC12 family are expressed; these include SLC12A2 (NKCC1), SLC12A4 (KCC1), SLC12A5 (KCC2), and SLC12A6 (KCC3) (Kanaka et al., 2001; Mikawa et al., 2002). Here, we review the literature on NKCC1, KCC2, and KCC3, which all have been studied in the brain in more detail (see Table 5 for neuronal and non-neuronal expression of SLC12 family).

\section{SLC12A2 (NKCC1)}

$\mathrm{NKCC1}$, which is an electroneutral $\mathrm{Na}^{+}-\mathrm{K}^{+}-2 \mathrm{Cl}^{-}$cotransporter, is one of the main $\mathrm{Cl}^{-}$accumulator in neurons (Brumback and Staley, 2008). Genetically modified animal models lacking NKCC1 show severe phenotypes, including: deafness due to inner ear dysfunction, deficits of spermatocyte production that lead to complete infertility, hypotension, reduction in saliva production, and sensory perception impairment due to abnormal responses of the dorsal root ganglion neurons to GABA release (Delpire et al., 1999; Dixon et al., 1999; Evans et al., 2000; Pace et al., 2000; Sung et al., 2000). Studies have shown that NKCC1 is heavily expressed in brain cells, including cerebellar neurons and glia. These studies reported that the expression of NKCC1 gradually decreases in cerebellar neurons except for granule cells (GrCs), which show robust expression in both neonatal and adult stages of the brain (Hübner et al., 2001; Kanaka et al., 2001; Li et al., 2002; Mikawa et al., 2002). It has been suggested that strong expression of NKCC1 in mature $\mathrm{GrCs}$ causes higher $\left[\mathrm{Cl}^{-}\right]_{\mathrm{i}}$ compared to 
other cerebellar neurons (Seja et al., 2012). NKCC1 is also repeatedly reported to be involved in cell volume control (Russell, 2000; Friedrich et al., 2006). Lowering $\left[\mathrm{Cl}^{-}\right]_{\mathrm{i}}$ and cell shrinkage stimulate NKCC1 ion transport activity, which is associated with increased levels of NKCC1 protein phosphorylation (Haas, 1994; Lytle, 1997).

\section{SLC12A5 (KCC2)}

KCC2 plays a crucial role in regulating cell volume as well as neuronal excitability (Payne et al., 2003; Kahle et al., 2015). Under normal physiological conditions the electrochemical balance dictates $\mathrm{K}^{+}$-efflux, which supports exchange of one $\mathrm{K}^{+}$ with one $\mathrm{Cl}^{-}$by $\mathrm{KCC} 2$ and leads to the reduction of $\left[\mathrm{Cl}^{-}\right]_{\mathrm{i}}$ (Figure 2). Although KCC2-mediated ion transport occurs in normal isotonic conditions, cell swelling causes a 20-fold increase in its activity (Song et al., 2002). In the cerebellum, KCC2 is expressed in PCs, GrCs, MLIs, and CN (Haas, 1994; Williams et al., 1999; Mikawa et al., 2002). At the subcellular level, KCC2 is detected at the plasma membrane and it is localized at both cell body and dendrites of PCs (Seja et al., 2012). Gramicidin-perforated patch-clamp recordings of PCs from PCspecific KCC2 knockout mice revealed that KCC2 is the major $\mathrm{Cl}^{-}$extruder of PCs (Seja et al., 2012). Studies on PC-specific and $\mathrm{GrC}$-specific knockouts of KCC2 indicated that their $\left[\mathrm{Cl}^{-}\right]_{\mathrm{i}}$ was doubled in both PCs and GrCs. This significant increase in $\left[\mathrm{Cl}^{-}\right]_{\mathrm{i}}$ almost eliminated GABA-induced hyperpolarization in PCs without affecting their resting membrane potential. In GrCs, which have been shown to have a more positive $\mathrm{E}_{\mathrm{GABA}}$ compared to RMP in normal physiological conditions (Seja et al., 2012), elevated $\left[\mathrm{Cl}^{-}\right]_{\mathrm{i}}$ caused higher excitability by depolarizing the resting membrane potential by $\sim 15 \mathrm{mV}$ (Seja et al., 2012). Utilizing cerebellar specific behavioral tests, such as compensatory eye movements, Seja et al. (2012) showed that KCC2 deletion in PCs resulted in impairments in baseline motor performance, as well as motor learning. GrC-specific KCC2 knockout mice did not show prominent deficits in their baseline motor performance, while they were significantly impaired in motor learning (for details see Seja et al., 2012).

\section{SLC12A6 (KCC3)}

KCC3 is a widespread $\mathrm{K}^{+}-\mathrm{Cl}^{-}$cotransporter, which particularly shows significant expression in brain and spinal cord (Pearson et al., 2001). In the cerebellum, KCC3 is expressed in cerebellar PCs (Pearson et al., 2001; Boettger et al., 2003). Conventional KCC3 knockout mice revealed important roles at cellular and behavioral levels. Deletion of KCC3 increased the $\left[\mathrm{Cl}^{-}\right]_{\mathrm{i}}$ in PCs and resulted in severe motor abnormalities. The knockout mice also showed hypertension, progressive neurodegeneration and deafness, as well as reduced seizure threshold (Boettger et al., 2003). However, later studies on PC-specific KCC3-KO mutant mice could not detect any difference with control mice neither at the cellular nor behavioral level (Seja et al., 2012). It has been proposed that KCC3 mostly functions as a volume regulator in mature neurons, while in immature neurons it may participate in modulation of $\left[\mathrm{Cl}^{-}\right]_{\mathrm{i}}$ and network development (Seja et al., 2012).

\section{LIGAND-GATED $\mathrm{CL}^{-}$CHANNELS}

Hyperpolarizing inhibition was discovered in 1951 by John C. Eccles and his colleagues (Brock et al., 1951). Their work on identification of ionic mechanisms underlying the generation of inhibitory postsynaptic potentials (IPSPs) and the activity of ligand-gated $\mathrm{Cl}^{-}$channels questioned the "passive distribution dogma" of $\mathrm{Cl}^{-}$. Ever since, researchers have been investigating the underlying mechanisms of $\left[\mathrm{Cl}^{-}\right]_{\mathrm{i}}$ regulation and neuronal inhibition in various parts of the brain (Table 6).

\subsection{GABA-Activated $\mathrm{Cl}^{-}$Channels}

Gamma-aminobutyric acid (GABA) is the main inhibitory neurotransmitter in the brain and plays vital roles in the development, migration, and assembly of neurons to create functional networks (Mcbain and Fisahn, 2001; Whittington and Traub, 2003; Farrant and Kaila, 2007). In the CNS, GABA receptors appear as ionotropic $\mathrm{GABA}_{\mathrm{A}}$ receptors $\left(\mathrm{GABA}_{\mathrm{A}} \mathrm{Rs}\right)$ and metabotropic $\mathrm{GABA}_{\mathrm{B}}$ receptors; the latter do not directly gate anions and therefore are not considered in this review.

TABLE 6 | Ligand-gated chloride channels.

\begin{tabular}{|c|c|c|c|c|c|c|}
\hline Channel & Expression & Function & Human disease & KO mouse & Pharmacology & References \\
\hline $\mathrm{GABA}_{A} R$ & $\begin{array}{l}\text { Nervous } \\
\text { system }\end{array}$ & $\begin{array}{l}\text { Inhibitory synaptic } \\
\text { transmission in the brain, } \\
\text { neuronal excitability and } \\
\text { development }\end{array}$ & $\begin{array}{l}\text { Epilepsy, movement } \\
\text { disorders, cognitive } \\
\text { disorders, autism, anxiety } \\
\text { disorders, schizophrenia, } \\
\text { sleep disorders, mood } \\
\text { disorders }\end{array}$ & $\begin{array}{l}\text { Epilepsy, movement } \\
\text { disorders, impaired } \\
\text { motor learning and } \\
\text { cognition }\end{array}$ & $\begin{array}{l}\text { Agonists: benzodiazepines, } \\
\text { barbiturates, zolpidem, } \\
\text { muscimol antagonists: } \\
\text { bicuculline, picrotoxin, } \mathrm{Cu}^{2+} \\
\text { (blocks tonic inhibition) }\end{array}$ & $\begin{array}{l}\text { Kaila, 1994; Möhler, 2006; } \\
\text { Wisden et al., 2009; } \\
\text { Gonzalez-Burgos et al., } \\
\text { 2011; Braat and Kooy, } 2015\end{array}$ \\
\hline GlyR & $\begin{array}{l}\text { Nervous } \\
\text { system }\end{array}$ & $\begin{array}{l}\text { Inhibitory synaptic } \\
\text { transmission in the } \\
\text { central nervous system, } \\
\text { neuronal excitability and } \\
\text { development }\end{array}$ & Startle disease, autism & $\begin{array}{l}\text { Natural occurring } \\
\text { mutation: startle } \\
\text { disease }\end{array}$ & $\begin{array}{l}\text { Agonists: Taurine, } \alpha \text { - } \mathrm{L} \text {-alanine, } \\
\mathrm{L} \text {-serine, low concentration of } \\
\mathrm{Zn}^{2+} \text {, antagonists: strychnine, } \\
\text { high concentration of } \mathrm{Zn}^{2+}\end{array}$ & $\begin{array}{l}\text { Curtis et al., 1968; Werman } \\
\text { et al., 1968; Lynch, 2004; } \\
\text { Burgos et al., 2016; Ito, } \\
2016\end{array}$ \\
\hline $\begin{array}{l}\text { SLC1A4 } \\
\text { (EAAT4) }\end{array}$ & $\begin{array}{l}\text { Nervous } \\
\text { system }\end{array}$ & $\begin{array}{l}\text { Glutamate } / \mathrm{Na}^{+} / \mathrm{Cl}^{-} \\
\text {transport, involved in } \\
\text { neuronal excitability and } \\
\text { development }\end{array}$ & $\begin{array}{l}\text { Neurodegenerative } \\
\text { disorders, stroke }\end{array}$ & $\begin{array}{l}\text { Down-regulation of } \\
\text { EAAT4 leads to PC } \\
\text { hyperexcitability }\end{array}$ & $\begin{array}{l}\text { Agonists: TBOA, } \\
\text { L- } \alpha \text {-aminoadipate, } \mathrm{T}^{\mathrm{M} M G}, \mathrm{Zn}^{2+} \\
\text { (selective blocker of } \mathrm{Cl}^{-} \\
\text {conductance) }\end{array}$ & $\begin{array}{l}\text { (Fairman et al., 1995; Nagao } \\
\text { et al., 1997; Fairman and } \\
\text { Amara, 1999) }\end{array}$ \\
\hline
\end{tabular}


$\mathrm{GABA}_{\mathrm{A}} \mathrm{Rs}$ are anion selective channels that are gated upon binding of GABA, permeable to $\mathrm{Cl}^{-}$and $\mathrm{HCO}_{3}^{-}$and mediate a fast postsynaptic current. Due to $\mathrm{GABA}_{\mathrm{A}} \mathrm{Rs}$ ' five times higher permeability to $\mathrm{Cl}^{-}$than $\mathrm{HCO}_{3}^{-}$and four times higher concentration of extracellular $\mathrm{Cl}^{-}$compared to $\mathrm{HCO}_{3}^{-},\left[\mathrm{Cl}^{-}\right]_{\mathrm{i}}$ is considered to be the main determinant of the direction of current through $\mathrm{GABA}_{\mathrm{A}}$ Rs (Staley, 2011). In other words, $\left[\mathrm{Cl}^{-}\right]_{\mathrm{i}}$ dictates the GABAergic reversal potential $\left(\mathrm{E}_{\mathrm{GABA}}\right)$. However, the permeability to $\mathrm{HCO}_{3}^{-}$functions as a depolarizing current through $\mathrm{GABA}_{\mathrm{A}}$ Rs. Therefore, the $\mathrm{E}_{\mathrm{GABA}}$ differs from $\mathrm{E}_{\mathrm{Cl}}$ to more positive values (Kaila and Voipio, 1987).

$\mathrm{GABA}_{\mathrm{A}}$ receptors are pentameric proteins composed of different subunits (Carlson et al., 1998). It is known that in human there are six $\alpha$ subunits, three $\beta$ subunits, three $\gamma$ subunits, three $\rho$ subunits, and one $\varepsilon, \delta, \theta$, and $\pi$ subunit (Sigel and Steinmann, 2012). This reflects the large diversity of subunit assembly, which is further increased by alternative splicing. The subunit composition, which is shown to be important for the kinetics and pharmacological properties of the receptor, changes during development (Succol et al., 2012). Whereas immature GABAergic synapses contain high expression levels of the $\alpha 3$ subunit, the adult isoform of $\mathrm{GABA}_{\mathrm{A}}$ receptor mainly contains $\alpha 1, \beta 2$, and $\gamma 2$ subunits (Ortinski et al., 2004). In the adult cerebellum, whole-cell recordings of spontaneous inhibitory postsynaptic currents (sIPSCs) in PCs and GrCs revealed differences between the shapes and decay times of the recorded currents. Purkinje cells typically express a combination of $\alpha 1$-, $\beta 2$, or $\beta 3$ - and $\gamma 2$-subunits, which mediates sIPSCs with a single fast exponential decay time constant, whereas GrCs, which specifically express the $\alpha 6$ subunit, show sIPSCs with the sum of fast and slow exponential curves, indicating that GrCs express both fast- and slow-mediated receptor compositions (Wisden, 1995). The variation in the expression of subunits does not only differ depending on the cell type, but also on subcellular location (e.g., soma vs. dendrites) (Wisden, 1995). To estimate the impact of local $\mathrm{GABA}_{\mathrm{A}}$ Rs on the membrane potential and $\left[\mathrm{Cl}^{-}\right]_{\mathrm{i}}$, one should consider the location together with the composition of subunits, which also determines the conductance level of the $\mathrm{GABA}_{\mathrm{A}}$ Rs (Porter et al., 1992; Angelotti and Macdonald, 1993). Studies on HEK293 cells showed that $\alpha 1 \beta 2 \gamma 2$ containing $\mathrm{GABA}_{\mathrm{A}} \mathrm{Rs}$, which is the composition expressed in mature cerebellar PCs, have the highest conductance of $30 \mathrm{pS}$ (Verdoorn et al., 1990).

Throughout the olivocerebellar system all cell-types appear to express $\mathrm{GABA}_{\mathrm{A}}$ Rs where they not only gate phasic inhibition, which is fast and lasts for milliseconds, but also gate tonic inhibition. The former type of synaptic inhibition is gated by synaptic $\mathrm{GABA}_{\mathrm{A}}$ Rs and the latter mostly by extrasynaptic GABA $_{\mathrm{A}}$ Rs (Wisden, 1995; Farrant and Nusser, 2005; Sigel and Steinmann, 2012). The targeting of $\mathrm{GABA}_{\mathrm{A}} \mathrm{Rs}$ to synaptic or extrasynaptic compartments is determined by the presence of specific subunits (Pirker et al., 2000). For instance, the $\gamma 2$ subunit is primarily expressed at synaptic sites, whereas the $\delta$ subunit is mostly present at extrasynaptic locations (Schweizer et al., 2003; Brickley and Mody, 2012; Brickley et al., 2013). In addition to phasic and tonic inhibition, spillover inhibition also occurs in cerebellar cortex, a phenomenon that is moderated by GABA spilling out of the synaptic cleft. For example, high affinity $\mathrm{GABA}_{\mathrm{A}} \mathrm{Rs}$ expressed on GrCs can sense low concentrations of GABA spilling out of their synapses with GoCs (Rossi and Hamann, 1998). The impact of GABA spillover in cerebellar cortex has also been demonstrated at excitatory terminals within the cerebellar glomerulus (Mitchell and Silver, 2000). In olivocerebellar system, some of the subunits of $\mathrm{GABA}_{\mathrm{A}} \mathrm{Rs}$ show ubiquitous expression, whereas others represent a restricted expression pattern, such as the $\alpha 6$ subunit, which is only expressed in cerebellar granule cells (Carlson et al., 1998; Sieghart and Sperk, 2002). Inferior olive neurons abundantly express $\alpha 2$, $\alpha 4$, and $\gamma 1$-subunits, while $\alpha 1, \alpha 3, \beta 2, \beta 3$, and $\gamma 2$ are detected at lower levels (Laurie et al., 1992). Expression of the $\alpha 3$ subunit appears to be restricted to the soma of olivary neurons and mediate a slow postsynaptic response to GABA (Bengtsson and Hesslow, 2006).

$\mathrm{GABA}_{\mathrm{A}} \mathrm{Rs}$ are involved in various brain disorders, including epilepsy, movement disabilities, cognitive disorders, anxiety disorders, mood disorders, schizophrenia, autism, and sleep disorders (Gonzalez-Burgos et al., 2011). Various synaptic connections in the olivocerebellar network are GABAergic and through the inhibition of postsynaptic neurons can not only dampen action potential firing, but also drive timed action potential firing in groups of neurons with strong pace-making activity, such as PCs and CNs and thereby promote synchronous activity (Wulff et al., 2009; Hoebeek et al., 2010; Buzsáki and Wang, 2012; Person and Raman, 2012). In addition, the direct projection from the cerebellum to the IO is GABAergic, which is crucial for modulating activity patterns in the olivo-cerebellarolivary loop (Bengtsson and Hesslow, 2006). Several studies have utilized the Cre-loxP system to create mouse models with specific deletion of GABAergic synapses in subsets of cells. For instance, deletion of the $\gamma 2$ subunit in PCs (PC- $\gamma 2 \mathrm{KO})$ leads to disruption of the receptor targeting to the postsynaptic membrane and selective removal of synaptic $\mathrm{GABA}_{\mathrm{A}}$ Rs from PCs (Wulff et al., 2009). These studies have shown that deletion of GABAergic input to PCs by removing $\mathrm{GABA}_{\mathrm{A}} \mathrm{Rs}$ alters the temporal pattern of $\mathrm{PC}$ activity by affecting the regularity of both spontaneous and parallel fiber-evoked simple spike firing. In vivo extracellular recordings of PCs from PC- $\gamma 2$ mice also showed higher simple spike firing regularity in the flocculus during compensatory eye movement and spontaneous behavior (Wulff et al., 2009), indicating that GABAergic inputs from MLIs to PCs may form the main source of irregularity in PC firing pattern (Häusser and Clark, 1997). Compensatory eye movement experiments on PC- $\gamma 2$ mice revealed severe motor learning deficits and supported the importance of GABAergic signaling and feed-forward inhibition in cerebellar learning (Wulff et al., 2009). Surprisingly, PC- $\gamma 2$ did not show ataxia, but only mild gait abnormalities (Veloz et al., 2015). In order to understand whether genetic compensatory mechanisms were involved in saving these mice from strong baseline motor deficits, Wisden and colleagues published a study in 2009 where they manipulated $\mathrm{GABA}_{\mathrm{A}}$ Rs by intraperitoneal injection of zolpidem (Wisden et al., 2009). To specifically study the MLI-PC synapse, they developed genetically modified mouse models, which were selectively sensitive to rapid manipulation of $\mathrm{GABA}_{\mathrm{A}} \mathrm{R}$ modulator zolpidem only at MLI-PC 
synapse (PC- $\gamma 2$-swap mice). PC- $\gamma 2$-swap mice showed severe motor abnormalities, highlighting the crucial role of MLI-PC synapse-mediated inhibition in motor control (Wisden et al., 2009). Studies have also examined the importance of GABAergic input to $\mathrm{GrCs}$ by eliminating Golgi cells; this manipulation caused overexcitation of GrCs and resulted in sever ataxia (Watanabe et al., 1998).

In the IO $\mathrm{GABA}_{\mathrm{A}}$ Rs modulate the strength of the inhibitory response to the afferent input from $\mathrm{CN}$. Apart from classical hyperpolarizing effects, the $\mathrm{CN}-\mathrm{IO}$ GABAergic synapses are suggested to be important for regulation of neuronal coupling in the olive (De Zeeuw et al., 2011). Thereby GABA-mediated inputs to the IO are not only affecting the excitability of olivary neurons, but also the local oscillations (Bazzigaluppi et al., 2012; De Gruijl et al., 2012). Both these mechanisms have profound effects on cerebellar PC and CN firing by means of CF innervation (De Zeeuw et al., 2011). For instance, it is shown that CFs regulate the synaptic plasticity at the level of PF-PC, as well as MLI-PC synapses by inducing long-term depression (LTD) and rebound potentiation (RP), respectively (Kano et al., 1992). Therefore, the activity level of olivary neurons can induce long-term changes at different cerebellar synapses (Kano et al., 1992; Gao et al., 2012; Ito, 2012; Hirano and Kawaguchi, 2014).

\subsection{Glycine-Activated $\mathrm{Cl}^{-}$Channels}

The glycine receptors (GlyRs) function as ligand-gated $\mathrm{Cl}^{-}$ channels. Similar to $\mathrm{GABA}_{\mathrm{A}}$ Rs, GlyRs mediate excitatory or inhibitory responses by promoting the efflux or influx of $\mathrm{Cl}^{-}$, respectively (Curtis et al., 1968; Werman et al., 1968)-the polarity is determined by the membrane potential and $\mathrm{E}_{\mathrm{Cl}}$. GlyRs are found throughout the central nervous system, with noticeable densities in the spinal cord, cerebellum, hippocampus, amygdala, hypothalamus, substantia nigra, cochlear nuclei, superior olivary complex, and trapezoid body (Zarbin et al., 1981; Flint et al., 1998; Ye et al., 1999; Mccool and Botting, 2000; Chattipakorn and McMahon, 2002; Gaiarsa et al., 2002; Mangin et al., 2002; Ye, 2007; Planells-Cases and Jentsch, 2009). GlyRs undergo developmental changes in their subunit composition. They mostly contain the $\alpha 2$ subunit at early stages of development, whereas the adult receptor contains $2 \alpha 1 / 3 \beta$ subunits (Becker et al., 1988; Lynch, 2004; Grudzinska et al., 2005). These subunits have different localizations and expression intensities. In the cerebellar cortex, GlyRs are labeled on the dendrites of Golgi cells where they receive inhibitory input from Lugaro cells (Dumoulin et al., 2001). In the $\mathrm{CN}$, there is a small group of glycinergic, or mixed glycinergic/GABAergic interneurons, which locally innervate principal CN neurons (Chan-Palay, 1977; Zeeuw and Berrebi, 1995). Studies by Husson and colleagues identified predominant expression of GlyRs on principal output $\mathrm{CN}$ neurons, where they receive inhibitory inputs from local $\mathrm{CN}$ interneurons (Husson et al., 2014). They showed that at these synapses GlyRs mediate $\mathrm{Cl}^{-}$currents and participate in inhibition of $\mathrm{CN}$ principal neurons, alike the GABAergic input from PCs. In addition, there is a subgroup of glycinergic projection neurons in the $\mathrm{CN}$ that adjusts the impact of glutamatergic inputs and facilitates vestibulocerebellar function (Bagnall et al., 2009).
Mutations in GlyRs have been identified in humans and cause autosomal dominant and recessive hyperekplexia or startle disease, which is characterized by pronounced and exaggerated responses to tactile or acoustic stimuli and hypertonia (Shiang et al., 1993). Natural occurring murine startle disease has been reported and shows similar phenotypes, such as reduced glycine sensitivity or reduced membrane expression of GlyRs. The specific impact of GlyRs in cerebellar activity has not been studied in detail yet. Most GlyRs seem to operate only during a limited developmental window and may contribute to the establishment of synaptic connections. In the developing cerebellum, in vitro whole-cell patch-clamp recordings of PCs from rats on postnatal days 3-10 (P3-P10) revealed a significant increase in frequencies of both excitatory and inhibitory postsynaptic currents (EPSCs and IPSCs) upon application of $100 \mu \mathrm{M}$ glycine (Kawa, 2003; Ye, 2007). These glycine-evoked synaptic events were abolished by application of strychnine $(1 \mu \mathrm{M})$, a specific blocker of the GlyRs (Kawa, 2003). Thus, ionotropic GlyRs may be transiently expressed in the developing cerebellum and play important roles in maturation and organization of cerebellar circuits (Kawa, 2003; Ye, 2007).

\subsection{Glutamate-Activated $\mathrm{Cl}^{-}$Channel (EAAT4)}

Excitatory amino acid transporters (EAATs) are known to play a crucial role in terminating glutamatergic transmission by uptake of glutamate from the synaptic cleft. This function is necessary to prevent glutamate receptor overstimulation (Robinson and Dowd, 1996; Dehnes et al., 1998). In addition, EAATs can function as glutamate-activated, $\mathrm{Na}^{+}$dependent $\mathrm{Cl}^{-}$channels (Fairman et al., 1995; Wadiche et al., 1995; Nagao et al., 1997). They belong to the solute carrier family 1 (SLC1), which contains five members: (EAAT1-EAAT5). EAAT4 is highly expressed in the cerebellum with an uneven parasagittal zonal distribution, which is very similar to that of Zebrin II (aldolase C) (Brochu et al., 1990; Dehnes et al., 1998). In situ hybridization, immunohistological studies and electron microscopy have revealed that EAAT4 is a postsynaptic transporter with predominant expression on PC spines where they receive inputs from PFs and CFs (Takahashi et al., 1996; Nagao et al., 1997; Otis et al., 1997). Other studies have reported the extrasynaptic expression of EAAT4 on PC spines, where it restricts glutamate spillover to neighboring synapses (Tanaka et al., 1997). Electrophysiological studies of PCs indicate that after glutamate release and high frequency action potential firing, EAAT4 increases its $\mathrm{Cl}^{-}$transport, which may serve as an extra force for limiting excessive PC firing (Dehnes et al., 1998). Given the preponderance of EAAT4 in the zebrin-positive zones, which probably all require a low baseline firing frequency of simple spikes so as to allow ample enhancement during motor learning (Zhou et al., 2014), this prevention fits in perfectly with ongoing hypotheses on the roles of zonally distributed forms of long-term postsynaptic potentiation and depression (De Zeeuw and Ten Brinke, 2015). 


\section{CONCLUDING REMARKS AND FUTURE PERSPECTIVES}

While the roles of $\mathrm{Cl}^{-}$channels and transporters are established and proven to be vital in various organs of the body, their impact on neuronal activity requires further investigations. Neurons express a rich set of plasma membrane $\mathrm{Cl}^{-}$channels and transporters, which belong to various protein families and have different modes of activation. The roles and regulations of many of these transporters and channels in the brain remain to be elucidated. As we have discussed here, $\mathrm{Cl}^{-}$transporting proteins show distinct expression patterns in the brain and are activated through different intra- and extracellular signaling pathways to establish and maintain the $\left[\mathrm{Cl}^{-}\right]_{\mathrm{i}}$. Investigating how $\mathrm{Cl}^{-}$channels and transporters function and how they interact to set the $\left[\mathrm{Cl}^{-}\right]_{\mathrm{i}}$ will help develop new strategies for treatment of various neurological conditions linked to aberrant $\mathrm{Cl}^{-}$homeostasis. The recent advances in fluorescent $\mathrm{Cl}^{-}$indicators have considerably helped with understanding the variability in $\left[\mathrm{Cl}^{-}\right]_{\mathrm{i}}$ and GABAergic signaling in different brain regions. Utilizing these $\mathrm{Cl}^{-}$indicators, the impact of $\mathrm{Cl}^{-}$ transporting proteins and other $\mathrm{Cl}^{-}$regulatory mechanisms on $\left[\mathrm{Cl}^{-}\right]_{\mathrm{i}}$ can be simultaneously visualized for hundreds of cells. However, the interpretation of the physiological and pathophysiological modifications in $\left[\mathrm{Cl}^{-}\right]_{\mathrm{i}}$ is not easy, because the intracellular $\mathrm{Cl}^{-}$dynamics are tightly intermingled with multiple cellular mechanisms, such as $\mathrm{pH}$ modifications and

\section{REFERENCES}

Abuladze, N., Yanagawa, N., Lee, I., Jo, O. D., Newman, D., Hwang, J., et al. (1998). Peripheral blood mononuclear cells express mutated NCCT mRNA in Gitelman's syndrome: evidence for abnormal thiazide-sensitive $\mathrm{NaCl}$ cotransport. J. Am. Soc. Nephrol. 9, 819-826.

Alka, K., and Casey, J. R. (2014). Bicarbonate transport in health and disease. IUBMB Life 66, 596-615. doi: 10.1002/iub.1315

Allen, N. J., and Attwell, D. (2002). Modulation of ASIC channels in rat cerebellar Purkinje neurons by ischaemia-related signals. J. Physiol. 543, 521-529. doi: 10.1113/jphysiol.2002.020297

Alper, S. L., and Sharma, A. K. (2013). The SLC26 gene family of anion transporters and channels. Mol. Aspects Med. 34, 494-515. doi: 10.1016/j.mam.2012.07.009

Alper, S. L., Stewart, A. K., Chernova, M. N., Zolotarev, A. S., Clark, J. S., and Vandorpe, D. H. (2006). Anion exchangers in flux: functional differences between human and mouse SLC26A6 polypeptides. Novartis Found Symp. 273, 107-119. doi: 10.1002/0470029579.ch8

Alshahrani, S., and Di Fulvio, M. (2012a). Enhanced insulin secretion and improved glucose tolerance in mice with homozygous inactivation of the $\mathrm{Na}^{+}$ $\mathrm{K}^{+} 2 \mathrm{Cl}^{-}$co-transporter 1. J. Endocrinol. 215, 59-70. doi: 10.1530/JOE-12-0244

Alshahrani, S., and Di Fulvio, M. (2012b). Expression of the Slc12al gene in pancreatic $\beta$-cells: molecular characterization and in silico analysis. Cell. Physiol. Biochem. 30, 95-112. doi: 10.1159/000339050

Amlal, H., Xu, J., Barone, S., Zahedi, K., and Soleimani, M. (2013). The chloride channel/transporter Slc26a9 regulates the systemic arterial pressure and renal chloride excretion. J. Mol. Med. 91, 561-572. doi: 10.1007/s00109-012-0973-1

Andersson, G., Garwicz, M., and Hesslow, G. (1988). Evidence for a GABAmediated cerebellar inhibition of the inferior olive in the cat. Exp. Brain Res. 72, 450-456. doi: 10.1007/BF00250590

Angaut, P., and Sotelo, C. (1989). Synaptology of the cerebello-olivary pathway. Double labelling with anterograde axonal tracing and GABA immunocytochemistry in the rat. Brain Res. 479, 361-365. doi: 10.1016/0006-8993(89)91641-7 membrane potential regulation. Therefore, $\mathrm{Cl}^{-}$dynamics need to be investigated by combining $\mathrm{Cl}^{-}$measurements with $\mathrm{pH}$ imaging and electrophysiological recordings. In addition, the significance of deletions or mutations of $\mathrm{Cl}^{-}$transporters and channels on regulating $\left[\mathrm{Cl}^{-}\right]_{\mathrm{i}}$ and neuronal activity needs to be analyzed while taking developmental compensations into account. Recent advances of genetic sequencing techniques such as RNA sequencing analysis have now made it possible to take a further step in investigating the impacts of genetic compensations. Together, these approaches will ultimately shed light on the complex interactions of various ionic channels and transporters and their up and/or down regulations during development and adulthood. In this manuscript, we reviewed the main $\mathrm{Cl}^{-}$channels and transporters currently known for the olivocerebellar system, which is implicated in various movement disorders and probably also in neurological diseases like epilepsy.

\section{AUTHOR CONTRIBUTIONS}

$\mathrm{NR}, \mathrm{FH}, \mathrm{SP}$, and CD contributed to writing the review paper.

\section{ACKNOWLEDGMENTS}

This review article covers sections of NR's thesis as part of her doctorate degree at Erasmus Medical Center in Rotterdam, The Netherlands in 2015 which can be accessed online.

Angelotti, T., and Macdonald, R. (1993). Assembly of GABAA receptor subunits: alpha 1 beta 1 and alpha 1 beta 1 gamma $2 S$ subunits produce unique ion channels with dissimilar single-channel properties. J. Neurosci. 13, 1429-1440. doi: 10.1523/JNEUROSCI.13-04-01429.1993

Ankri, L., Husson, Z., Pietrajtis, K., Proville, R., Léna, C., Yarom, Y., et al. (2015). A novel inhibitory nucleo-cortical circuit controls cerebellar Golgi cell activity. Elife 4:e06262. doi: 10.7554/eLife.06262

Annegers, J. F., Hauser, W. A., Coan, S. P., and Rocca, W. A. (1998). A populationbased study of seizures after traumatic brain injuries. Eng. J. Med. 338, 20-24. doi: 10.1056/NEJM199801013380104

Aronson, P. S. (2006). Role of SLC26-mediated $\mathrm{Cl}^{-} /$base exchange in proximal tubule $\mathrm{NaCl}$ transport. Novartis Found. Symp. 273, 148-158. doi: $10.1002 / 0470029579 . \operatorname{ch} 10$

Arroyo, J. P., Kahle, K. T., and Gamba, G. (2013). The SLC12 family of electroneutral cation-coupled chloride cotransporters. Mol. Aspects Med. 34, 288-298. doi: 10.1016/j.mam.2012.05.002

Bagnall, M. W., Zingg, B., Sakatos, A., Moghadam, S. H., Zeilhofer, H. U., and Du Lac, S. (2009). Glycinergic projection neurons of the cerebellum. J. Neurosci. 29, 10104-10110. doi: 10.1523/JNEUROSCI.2087-09.2009

Balestrino, M., and Somjen, G. (1988). Concentration of carbon dioxide, interstitial $\mathrm{pH}$ and synaptic transmission in hippocampal formation of the rat. J. Physiol. 396, 247-266. doi: 10.1113/jphysiol.1988.sp016961

Bazzigaluppi, P., De Gruijl, J. R., Van Der Giessen, R. S., Khosrovani, S., De Zeeuw, C. I., and De Jeu, M. T. (2012). Olivary subthreshold oscillations and burst activity revisited. Front. Neural Circuits 6:91. doi: 10.3389/fncir.2012.00091

Becker, C.-M., Hoch, W., and Betz, H. (1988). Glycine receptor heterogeneity in rat spinal cord during postnatal development. EMBO J. 7 , 3717-3726.

Ben-Ari, Y. (2002). GABA excitation during development: the nature of the nurture. Neurophysiology 34, 81-82. doi: 10.1023/A:1020771529666

Ben-Ari, Y. (2017). NKCC1 chloride importer antagonists attenuate many neurological and psychiatric disorders. Trends Neurosci. 40, 536-554. doi: 10.1016/j.tins.2017.07.001 
Ben-Ari, Y., Gaiarsa, J.-L., Tyzio, R., and Khazipov, R. (2007). GABA: a pioneer transmitter that excites immature neurons and generates primitive oscillations. Physiol. Rev. 87, 1215-1284. doi: 10.1152/physrev.00017.2006

Ben-Ari, Y., Khazipov, R., Leinekugel, X., Caillard, O., and Gaiarsa, J.-L. (1997). $\mathrm{GABA}_{\mathrm{A}}, \mathrm{NMDA}$ and AMPA receptors: a developmentally regulated 'ménage à trois'. Trends Neurosci. 20, 523-529. doi: 10.1016/S0166-2236(97)01147-8

Bengtsson, F., and Hesslow, G. (2006). Cerebellar control of the inferior olive. Cerebellum 5, 7-14. doi: 10.1080/14734220500462757

Bi, M. M., Hong, S., Zhou, H. Y., Wang, H. W., Wang, L. N., and Zheng, Y. J. (2013). Chloride channelopathies of ClC-2. Int. J. Mol. Sci. 15, 218-249. doi: 10.3390/ijms15010218

Billig, G. M., Pál, B., Fidzinski, P., and Jentsch, T. J. (2011). $\mathrm{Ca}^{2+}$-activated $\mathrm{Cl}^{-}$currents are dispensable for olfaction. Nat. Neurosci. 14, 763-769. doi: $10.1038 / \mathrm{nn} .2821$

Blanz, J., Schweizer, M., Auberson, M., Maier, H., Muenscher, A., Hübner, C. A., et al. (2007). Leukoencephalopathy upon disruption of the chloride channel ClC-2. J. Neurosci. 27, 6581-6589. doi: 10.1523/JNEUROSCI.0338-07.2007

Boettger, T., Rust, M. B., Maier, H., Seidenbecher, T., Schweizer, M., Keating, D. J., et al. (2003). Loss of $\mathrm{K}-\mathrm{Cl}$ co-transporter KCC3 causes deafness, neurodegeneration and reduced seizure threshold. EMBO J. 22, 5422-5434. doi: 10.1093/emboj/cdg519

Bormann, J., Hamill, O. P., and Sakmann, B. (1987). Mechanism of anion permeation through channels gated by glycine and gamma-aminobutyric acid in mouse cultured spinal neurones. J. Physiol. 385, 243-286. doi: 10.1113/jphysiol.1987.sp016493

Borsani, G., Rugarli, E. I., Taglialatela, M., Wong, C., and Ballabio, A. (1995). Characterization of a human and murine gene (CLCN3) sharing similarities to voltage-gated chloride channels and to a yeast integral membrane protein. Genomics 27, 131-141. doi: 10.1006/geno.1995.1015

Braat, S., and Kooy, R. F. (2015). The $\mathrm{GABA}_{\mathrm{A}}$ receptor as a therapeutic target for neurodevelopmental disorders. Neuron 86, 1119-1130. doi: 10.1016/j.neuron.2015.03.042

Branchereau, P., Cattaert, D., Delpy, A., Allain, A.-E., Martin, E., and Meyrand, P. (2016). Depolarizing GABA/glycine synaptic events switch from excitation to inhibition during frequency increases. Sci. Rep. 6:21753. doi: 10.1038/srep21753

Brandt, S., and Jentsch, T. J. (1995). ClC-6 and ClC-7 are two novel broadly expressed members of the CLC chloride channel family. FEBS Lett. 377, 15-20. doi: 10.1016/0014-5793(95)01298-2

Brickley, S. G., and Mody, I. (2012). Extrasynaptic GABAA receptors: their function in the CNS and implications for disease. Neuron 73, 23-34. doi: 10.1016/j.neuron.2011.12.012

Brickley, S. G., Ye, Z., Mcgee, T. P., and Houston, C. M. (2013). The contribution of $\delta$ subunit-containing GABAA receptors to phasic and tonic conductance changes in cerebellum, thalamus and neocortex. Front. Neural Circuits 7:203. doi: $10.3389 /$ fncir.2013.00203

Brochu, G., Maler, L., and Hawkes, R. (1990). Zebrin II: a polypeptide antigen expressed selectively by Purkinje cells reveals compartments in rat and fish cerebellum. J. Comp. Neurol. 291, 538-552. doi: 10.1002/cne.902910405

Brock, L., Coombs, J., and Eccles, J. (1951). "Action potentials of motoneurones with intracellular electrode," in Proceeding of the University of Otago Medical School (Dunedin), 14-15.

Bruce, L. J., Cope, D. L., Jones, G.K., Schofield, A. E., Burley, M., Povey, S., et al. (1997). Familial distal renal tubular acidosis is associated with mutations in the red cell anion exchanger (Band 3, AE1) gene. J. Clin. Invest. 100, 1693-1707. doi: 10.1172/JCI1 19694

Brumback, A. C., and Staley, K. J. (2008). Thermodynamic regulation of NKCC1-mediated $\mathrm{Cl}^{-}$cotransport underlies plasticity of GABAA signaling in neonatal neurons. J. Neurosci. 28, 1301-1312. doi: 10.1523/JNEUROSCI.337807.2008

Burette, A. C., Weinberg, R. J., Sassani, P., Abuladze, N., Kao, L., and Kurtz, I. (2012). The sodium-driven chloride/bicarbonate exchanger in presynaptic terminals. J. Comp. Neurol. 520, 1481-1492. doi: 10.1002/cne.22806

Burgos, C. F., Yévenes, G. E., and Aguayo, L. G. (2016). Structure and pharmacologic modulation of inhibitory glycine receptors. Mol. Pharmacol. 90, 318-325. doi: 10.1124/mol.116.105726

Buzsáki, G., and Wang, X.-J. (2012). Mechanisms of gamma oscillations. Annu. Rev. Neurosci. 35, 203-225. doi: 10.1146/annurev-neuro-062111-150444
Carlson, B. X., Elster, L., and Schousboe, A. (1998). Pharmacological and functional implications of developmentally-regulated changes in GABA A receptor subunit expression in the cerebellum. Eur. J. Pharmacol. 352, 1-14. doi: 10.1016/S0014-2999(98)00355-0

Castrop, H., and Schießl, I. M. (2014). Physiology and pathophysiology of the renal Na-K-2Cl cotransporter (NKCC2). Am. J. Physiol. Renal Physiol. 307, F991-F1002. doi: 10.1152/ajprenal.00432.2014

Chamard, L., Sylvestre, G., Koenig, M., and Magnin, E. (2016). Executive and attentional disorders, epilepsy and porencephalic cyst in autosomal recessive cerebellar ataxia type 3 due to ANO10 mutation. Eur. Neurol. 75, 186-190. doi: 10.1159/000445109

Chang, H., Tashiro, K., Hirai, M., Ikeda, K., Kurokawa, K., and Fujita, T. (1996). Identification of a cDNA encoding a thiazide-sensitive sodium-chloride cotransporter from the human and its mRNA expression in various tissues. Biochem. Biophys. Res. Commun. 223, 324-328. doi: 10.1006/bbrc.1996.0893

Chan-Palay, V. (1977). "The cerebellar dentate nucleus," in Cerebellar Dentate Nucleus (Berlin; Heidelberg: Springer), 1-24.

Charlesworth, G., Plagnol, V., Holmström, K. M., Bras, J., Sheerin, U.-M., Preza, E., et al. (2012). Mutations in ANO3 cause dominant craniocervical dystonia: ion channel implicated in pathogenesis. Am J. Hum. Genet. 91, 1041-1050. doi: 10.1016/j.ajhg.2012.10.024

Chattipakorn, S. C., and McMahon, L. L. (2002). Pharmacological characterization of glycine-gated chloride currents recorded in rat hippocampal slices. J. Neurophysiol. 87, 1515-1525. doi: 10.1152/jn.00365.2001

Cheatham, M., Huynh, K., Gao, J., Zuo, J., and Dallos, P. (2004). Cochlear function in Prestin knockout mice. J. Physiol. 560, 821-830. doi: 10.1113/jphysiol.2004.069559

Chen, H., Ordog, T., Chen, J., Young, D. L., Bardsley, M. R., Redelman, D., et al. (2007). Differential gene expression in functional classes of interstitial cells of Cajal in murine small intestine. Physiol. Genomics 31, 492-509. doi: 10.1152/physiolgenomics.00113.2007

Chen, L.-M., Kelly, M. L., Parker, M. D., Bouyer, P., Gill, H. S., Felie, J. M., et al. (2008). Expression and localization of Na-driven $\mathrm{Cl}-$ HCO3- exchanger (SLC4A8) in rodent CNS. Neuroscience 153, 162-174. doi: 10.1016/j.neuroscience.2008.02.018

Chen, T. T., Klassen, T. L., Goldman, A. M., Marini, C., Guerrini, R., and Noebels, J. L. (2013). Novel brain expression of ClC-1 chloride channels and enrichment of CLCN1 variants in epilepsy. Neurology 80, 1078-1085. doi: 10.1212/WNL.0b013e31828868e7

Cherubini, E., Gaiarsa, J. L., and Ben-Ari, Y. (1991). GABA: an excitatory transmitter in early postnatal life. Trends Neurosci. 14, 515-519. doi: 10.1016/0166-2236(91)90003-D

Chesler, M., and Kaila, K. (1992). Modulation of $\mathrm{pH}$ by neuronal activity. Trends Neurosci. 15, 396-402. doi: 10.1016/0166-2236(92)90191-A

Cho, H., Yang, Y. D., Lee, J., Lee, B., Kim, T., Jang, Y., et al. (2012). The calciumactivated chloride channel anoctamin 1 acts as a heat sensor in nociceptive neurons. Nat. Neurosci. 15, 1015-1021. doi: 10.1038/nn.3111

Clayton, G. H., Staley, K. J., Wilcox, C. L., Owens, G. C., and Smith, R. L. (1998), Developmental expression of ClC-2 in the rat nervous system. Dev. Brain Res. 108, 307-318. doi: 10.1016/S0165-3806(98)00045-5

Cohen, I., Navarro, V., Clemenceau, S., Baulac, M., and Miles, R. (2002). On the origin of interictal activity in human temporal lobe epilepsy in vitro. Science 298, 1418-1421. doi: 10.1126/science. 1076510

Costanzo, L. S. (1985). Localization of diuretic action in microperfused rat distal tubules: Ca and Na transport. Am J. Physiol. Renal Physiol. 248, F527-F535. doi: 10.1152/ajprenal.1985.248.4.F527

Courjaret, R., and Machaca, K. (2014). Mid-range $\mathrm{Ca}^{2+}$ signalling mediated by functional coupling between store-operated $\mathrm{Ca}^{2+}$ entry and IP3-dependent $\mathrm{Ca}^{2+}$ release. Nat. Commun. 5:3916. doi: 10.1038/ncomms4916

Crepel, F., Mariani, J., and Delhaye-Bouchaud, N. (1976). Evidence for a multiple innervation of Purkinje cells by climbing fibers in the immature rat cerebellum. Dev. Neurobiol. 7, 567-578. doi: 10.1002/neu.480070609

Curtis, D., Hösli, L., Johnston, G., and Johnston, I. (1968). The hyperpolarization of spinal motoneurones by glycine and related amino acids. Exp. Brain Res. 5, 235-258. doi: 10.1007/BF00238666

Dauner, K., Möbus, C., Frings, S., and Möhrlen, F. (2013). Targeted expression of anoctamin calcium-activated chloride channels in rod photoreceptor 
terminals of the rodent retina. Invest. Ophthalmol. Vis. Sci. 54, 3126-3136. doi: $10.1167 /$ iovs.13-11711

De Gruijl, J. R., Bazzigaluppi, P., De Jeu, M. T., and De Zeeuw, C. I. (2012). Climbing fiber burst size and olivary sub-threshold oscillations in a network setting. PLoS Comput. Biol. 8:e1002814. doi: 10.1371/journal.pcbi.1002814

De Gruijl, J. R., Sokół, P. A., Negrello, M., and De Zeeuw, C. I. (2014). Modulation of electrotonic coupling in the inferior olive by inhibitory and excitatory inputs: integration in the glomerulus. Neuron 81, 1215-1217. doi: 10.1016/j.neuron.2014.03.009

Dehnes, Y., Chaudhry, F. A., Ullensvang, K., Lehre, K. P., Storm-Mathisen, J., and Danbolt, N. C. (1998). The glutamate transporter EAAT4 in rat cerebellar Purkinje cells: a glutamate-gated chloride channel concentrated near the synapse in parts of the dendritic membrane facing astroglia. J. Neurosci. 18, 3606-3619.

Deidda, G., Bozarth, I. F., and Cancedda, L. (2014). Modulation of GABAergic transmission in development and neurodevelopmental disorders: investigating physiology and pathology to gain therapeutic perspectives. Front. Cell. Neurosci. 8:119. doi: 10.3389/fncel.2014.00119

Delpire, E., Lu, J., England, R., Dull, C., and Thorne, T. (1999). Deafness and imbalance associated with inactivation of the secretory $\mathrm{Na}-\mathrm{K}-2 \mathrm{Cl}$ cotransporter. Nat. Genet. 22, 192-195. doi: 10.1038/9713

Delpire, E., Wolfe, L., Flores, B., Koumangoye, R., Schornak, C. C., Omer, S., et al. (2016). A patient with multisystem dysfunction carries a truncation mutation in human SLC12A2, the gene encoding the Na-K-2Cl cotransporter, NKCC1. Cold. Spring Harb. Mol. Case Stud. 2:a001289. doi: 10.1101/mcs.a001289

De Zeeuw, C., Holstege, J., Ruigrok, T., and Voogd, J. (1989). Ultrastructural study of the GABAergic, cerebellar, and mesodiencephalic innervation of the cat medial accessory olive: anterograde tracing combined with immunocytochemistry. J. Comp. Neurol. 284, 12-35. doi: $10.1002 /$ cne. 902840103

De Zeeuw, C. I., Hoebeek, F. E., Bosman, L. W., Schonewille, M., Witter, L., and Koekkoek, S. K. (2011). Spatiotemporal firing patterns in the cerebellum. Nat. Rev. Neurosci. 12, 327-344. doi: 10.1038/nrn3011

De Zeeuw, C. I., Hoogenraad, C. C., Koekkoek, S., Ruigrok, T. J., Galjart, N., and Simpson, J. I. (1998). Microcircuitry and function of the inferior olive. Trends Neurosci. 21, 391-400. doi: 10.1016/S0166-2236(98)01310-1

De Zeeuw, C. I., and Ten Brinke, M. M. (2015). Motor learning and the cerebellum. Cold Spring Harb. Perspect. Biol. 7:a021683. doi: 10.1101/cshperspect.a0 21683

Dixon, M. J., Gazzard, J., Chaudhry, S. S., Sampson, N., Schulte, B. A., and Steel, K. P. (1999). Mutation of the Na-K-Cl co-transporter gene Slc12a2 results in deafness in mice. Hum. Mol. Genet. 8, 1579-1584. doi: 10.1093/hmg/8.8.1579

Doyon, N., Vinay, L., Prescott, S. A., and De Koninck, Y. (2016). Chloride regulation: a dynamic equilibrium crucial for synaptic inhibition. Neuron 89, 1157-1172. doi: 10.1016/j.neuron.2016.02.030

Dumoulin, A., Triller, A., and Dieudonné, S. (2001). IPSC kinetics at identified GABAergic and mixed GABAergic and glycinergic synapses onto cerebellar Golgi cells. J. Neurosci. 21, 6045-6057.

Duvvuri, U., Shiwarski, D. J., Xiao, D., Bertrand, C., Huang, X., Edinger, R. S., et al. (2012). TMEM16A induces MAPK and contributes directly to tumorigenesis and cancer progression. Cancer Res. 72, 3270-3281. doi: 10.1158/0008-5472.CAN-12-0475-T

Dzhala, V. I., Brumback, A. C., and Staley, K. J. (2008). Bumetanide enhances phenobarbital efficacy in a neonatal seizure model. Ann. Neurol. 63, 222-235. doi: 10.1002/ana.21229

Dzhala, V. I., Talos, D. M., Sdrulla, D. A., Brumback, A. C., Mathews, G. C., Benke, T. A., et al. (2005). NKCC1 transporter facilitates seizures in the developing brain. Nat. Med. 11, 1205-1213. doi: 10.1038/nm1301

Evans, R. L., Park, K., Turner, R. J., Watson, G. E., Nguyen, H.-V., Dennett, M. R., et al. (2000). Severe impairment of salivation in $\mathrm{Na}^{+} / \mathrm{K}^{+} / 2 \mathrm{Cl}^{-}$ cotransporter (NKCC1)-deficient mice. J. Biol. Chem. 275, 26720-26726. doi: 10.1074/jbc.M003753200

Everett, L. A., Glaser, B., Beck, J. C., Idol, J. R., Buchs, A., Adawi, F., et al. (1997). Pendred syndrome is caused by mutations in a putative sulphate transporter gene (PDS). Nat. Genet. 17, 411-422. doi: 10.1038/ng1297-411

Ellison, D. H., Velazquez, H., and Wright, F. S. (1987). Thiazide-sensitive sodium chloride cotransport in early distal tubule. Am. J. Physiol. Renal Physiol. 253, F546-F554. doi: 10.1152/ajprenal.1987.253.3.F546
Fairman, W., and Amara, S. (1999). Functional diversity of excitatory amino acid transporters: ion channel and transport modes. Am. J. Physiol Renal Physiol. 277, F481-F486. doi: 10.1152/ajprenal.1999.277.4.F481

Fairman, W., Vandenberg, R., Arriza, J., Kavanaugh, M., and Amara, S. (1995). An excitatory amino-acid transporter with properties of a ligand-gated chloride channel. Nature 375, 599-603. doi: 10.1038/375599a0

Fakler, B., and Adelman, J. P. (2008). Control of K Ca channels by calcium nano/microdomains. Neuron 59, 873-881. doi: 10.1016/j.neuron.2008.09.001

Farmer, L. M., Le, B. N., and Nelson, D. J. (2013). CLC-3 chloride channels moderate long-term potentiation at Schaffer collateral-CA1 synapses. J. Physiol. 591, 1001-1015. doi: 10.1113/jphysiol.2012.243485

Farrant, M., and Kaila, K. (2007). The cellular, molecular and ionic basis of GABA A receptor signalling. Prog. Brain Res. 160, 59-87. doi: 10.1016/S0079-6123(06)60005-8

Farrant, M., and Nusser, Z. (2005). Variations on an inhibitory theme: phasic and tonic activation of GABAA receptors. Nat. Rev. Neurosci. 6, 215-229. doi: 10.1038/nrn1625

Flint, A. C., Liu, X., and Kriegstein, A. R. (1998). Nonsynaptic glycine receptor activation during early neocortical development. Neuron 20, 43-53. doi: 10.1016/S0896-6273(00)80433-X

Flores, B., Schornak, C., Wolfe, L., Adams, D., and Delpire, E. (2016). Functional characterization of the first known mutation of the human SLC12A2 (NKCC1) Gene. FASEB J. 30, 1222-1224.

Fredette, B. J., and Mugnaini, E. (1991). The GABAergic cerebello-olivary projection in the rat. Anat. Embryol. 184, 225-243. doi: 10.1007/BF01673258

Frey, A., Lampert, A., Waldegger, S., Jeck, N., Waldegger, P., Artunc, F., et al. (2006). Influence of gain of function epithelial chloride channel $\mathrm{ClC}-\mathrm{Kb}$ mutation on hearing thresholds. Hear. Res. 214, 68-75. doi: 10.1016/j.heares.2006.02.001

Friedel, P., Kahle, K. T., Zhang, J., Hertz, N., Pisella, L. I., Buhler, E., et al. (2015). WNK1-regulated inhibitory phosphorylation of the KCC2 cotransporter maintains the depolarizing action of GABA in immature neurons. Sci. Signal. 8:ra65. doi: 10.1126/scisignal.aaa0354

Friedrich, B., Matskevich, I., and Lang, F. (2006). "Cell volume regulatory mechanisms," in Mechanisms and Significance of Cell Volume Regulation, ed F. Lang (Tübingen: Karger Publishers), 1-8.

Gaiarsa, J.-L., Caillard, O., and Ben-Ari, Y. (2002). Long-term plasticity at GABAergic and glycinergic synapses: mechanisms and functional significance. Trends Neurosci. 25, 564-570. doi: 10.1016/S0166-2236(02)02269-5

Galeffi, F., Sah, R., Pond, B. B., George, A., and Schwartz-Bloom, R. D. (2004). Changes in intracellular chloride after oxygen-glucose deprivation of the adult hippocampal slice: effect of diazepam. J. Neurosci. 24, 4478-4488. doi: 10.1523/JNEUROSCI.0755-04.2004

Gao, Z., Van Beugen, B. J., and De Zeeuw, C. I. (2012). Distributed synergistic plasticity and cerebellar learning. Nat. Rev. Neurosci. 13, 619-635. doi: $10.1038 / \mathrm{nrn} 3312$

Gawenis, L. R., Ledoussal, C., Judd, L. M., Prasad, V., Alper, S. L., Stuart-Tilley, A., et al. (2004). Mice with a targeted disruption of the AE2 exchanger are achlorhydric. J. Biol. Chemi. 279, 30531-30539. doi: 10.1074/jbc.M403779200

Ge, Y.-X., Liu, Y., Tang, H.-Y., Liu, X.-G., and Wang, X. (2011). ClC-2 contributes to tonic inhibition mediated by $\alpha 5$ subunit-containing GABA A receptor in experimental temporal lobe epilepsy. Neuroscience 186, 120-127. doi: 10.1016/j.neuroscience.2011.04.029

Glykys, J., Dzhala, V., Egawa, K., Balena, T., Saponjian, Y., Kuchibhotla, K., et al. (2014). Local impermeant anions establish the neuronal chloride concentration. Science 343, 670-675. doi: 10.1126/science.1245423

Glykys, J., Dzhala, V., Egawa, K., Kahle, K. T., Delpire, E., and Staley, K. (2017). Chloride dysregulation, seizures, and cerebral edema: a relationship with therapeutic potential. Trends Neurosci. 40, 276-294. doi: 10.1016/j.tins.2017.03.006

Gonzalez-Burgos, G., Fish, K. N., and Lewis, D. A. (2011). GABA neuron alterations, cortical circuit dysfunction and cognitive deficits in schizophrenia. Neural Plast. 2011:723184. doi: 10.1155/2011/723184

Greer, P. L., and Greenberg, M. E. (2008). From synapse to nucleus: calciumdependent gene transcription in the control of synapse development and function. Neuron 59, 846-860. doi: 10.1016/j.neuron.2008.09.002

Griffin, D. A., Johnson, R. W., Whitlock, J. M., Pozsgai, E. R., Heller, K. N., Grose, W. E., et al. (2016). Defective membrane fusion and repair in 
Anoctamin5-deficient muscular dystrophy. Hum. Mol. Genet. 25, 1900-1911. doi: $10.1093 / \mathrm{hmg} / \mathrm{ddw} 063$

Grubb, B., Lee, E., Pace, A., Koller, B., and Boucher, R. (2000). Intestinal ion transport in NKCC1-deficient mice. Am. J. Physiol. Gastrointestinal Liver Physiol. 279, G707-G718. doi: 10.1152/ajpgi.2000.279.4.G707

Grubb, S., Poulsen, K. A., Juul, C. A., Kyed, T., Klausen, T. K., Larsen, E. H., et al. (2013). TMEM16F (Anoctamin 6), an anion channel of delayed $\mathrm{Ca}^{2+}$ activation. J. Gen. Physiol. 141, 585-600. doi: 10.1085/jgp.201210861

Grudzinska, J., Schemm, R., Haeger, S., Nicke, A., Schmalzing, G., Betz, H., et al. (2005). The $\beta$ subunit determines the ligand binding properties of synaptic glycine receptors. Neuron 45, 727-739. doi: 10.1016/j.neuron.2005.01.028

Guan, L., Song, Y., Gao, J., Gao, J., and Wang, K. (2016). Inhibition of calcium-activated chloride channel ANO1 suppresses proliferation and induces apoptosis of epithelium originated cancer cells. Oncotarget 7, 78619-78630. doi: 10.18632/oncotarget.12524

Günther, W., Lüchow, A., Cluzeaud, F., Vandewalle, A., and Jentsch, T. J. (1998). ClC-5, the chloride channel mutated in Dent's disease, colocalizes with the proton pump in endocytotically active kidney cells. Proc. Natl. Acad. Sci. U.S.A. $95,8075-8080$.

Gyobu, S., Miyata, H., Ikawa, M., Yamazaki, D., Takeshima, H., Suzuki, J., et al. (2016). A role of TMEM16E carrying a scrambling domain in sperm motility. Mol. Cell. Biol. 36, 645-659. doi: 10.1128/MCB.00919-15

Ha, G. E., Lee, J., Kwak, H., Song, K., Kwon, J., Jung, S.-Y., et al. (2016). The $\mathrm{Ca}^{2+}$ _ activated chloride channel anoctamin-2 mediates spike-frequency adaptation and regulates sensory transmission in thalamocortical neurons. Nat. Commun. 7:13791. doi: $10.1038 /$ ncomms 13791

Haas, M. (1994). The Na-K-Cl cotransporters. Am. J. Physiol. Cell Physiol. 267, C869-C885. doi: 10.1152/ajpcell.1994.267.4.C869

Hashimoto, K., and Kano, M. (2005). Postnatal development and synapse elimination of climbing fiber to Purkinje cell projection in the cerebellum. Neurosci. Res. 53, 221-228. doi: 10.1016/j.neures.2005.07.007

Hashimoto, K., Tsujita, M., Miyazaki, T., Kitamura, K., Yamazaki, M., Shin, H. -S., et al. (2011). Postsynaptic P/Q-type $\mathrm{Ca}^{2+}$ channel in Purkinje cell mediates synaptic competition and elimination in developing cerebellum. Proc. Natl. Acad. Sci. 108, 9987-9992. doi: 10.1073/pnas.1101488108

Hästbacka, J., De La Chapelle, A., Mahtani, M. M., Clines, G., Reeve-Daly, M. P., Daly, M., et al. (1994). The diastrophic dysplasia gene encodes a novel sulfate transporter: positional cloning by fine-structure linkage disequilibrium mapping. Cell 78, 1073-1087. doi: 10.1016/0092-8674(94)90281-X

Häusser, M., and Clark, B. A. (1997). Tonic synaptic inhibition modulates neuronal output pattern and spatiotemporal synaptic integration. Neuron 19, 665-678. doi: 10.1016/S0896-6273(00)80379-7

Hebert, S. C., Mount, D. B., and Gamba, G. (2004). Molecular physiology of cation-coupled Cl- cotransport: the SLC12 family. Pflügers Arch. 447, 580-593. doi: $10.1007 / \mathrm{s} 00424-003-1066-3$

Hentschke, M., Wiemann, M., Hentschke, S., Kurth, I., Hermans-Borgmeyer, I., Seidenbecher, T., et al. (2006). Mice with a targeted disruption of the $\mathrm{Cl}-$ /HCO3- exchanger AE3 display a reduced seizure threshold. Mol. Cell. Biol. 26, 182-191. doi: 10.1128/MCB.26.1.182-191.2006

Hirano, T., and Kawaguchi, S.-Y. (2014). Regulation and functional roles of rebound potentiation at cerebellar stellate cell-Purkinje cell synapses. Front. Cell. Neurosci. 8:42. doi: 10.3389/fncel.2014.00042

Hoebeek, F. E., Witter, L., Ruigrok, T. J., and De Zeeuw, C. I. (2010). Differential olivo-cerebellar cortical control of rebound activity in the cerebellar nuclei. Proc. Natl. Acad. Sci. U.S.A. 107, 8410-8415. doi: 10.1073/pnas.0907118107

Höglund, P., Haila, S., Socha, J., Tomaszewski, L., Saarialho-Kere, U., KarjalainenLindsberg, M.-L., et al. (1996). Mutations of the Down-regulated in adenoma (DRA) gene cause congenital chloride diarrhoea. Nat. Genet. 14, 316-319.

Huang, F., Rock, J. R., Harfe, B. D., Cheng, T., Huang, X., Jan, Y. N., et al. (2009). Studies on expression and function of the TMEM16A calciumactivated chloride channel. Proc. Natl. Acad. Sci. U.S.A. 106, 21413-21418. doi: 10.1073/pnas.0911935106

Huang, F., Wang, X., Ostertag, E. M., Nuwal, T., Huang, B., Jan, Y.-N., et al. (2013a). TMEM16C facilitates $\mathrm{Na}^{+}$-activated $\mathrm{K}^{+}$currents in rat sensory neurons and regulates pain processing. Nat. Neurosci. 16, 1284-1290. doi: $10.1038 / \mathrm{nn} .3468$

Huang, W. C., Xiao, S., Huang, F., Harfe, B. D., Jan, Y. N., and Jan, L. Y. (2012). Calcium-activated chloride channels (CaCCs) regulate action potential and synaptic response in hippocampal neurons. Neuron 74, 179-192. doi: 10.1016/j.neuron.2012.01.033

Huang, Y., Wang, J.-J., and Yung, W.-H. (2013b). Coupling between GABAA receptor and chloride transporter underlies ionic plasticity in cerebellar purkinje neurons. Cerebellum 12, 328-330. doi: 10.1007/s12311-013-0453-3

Hübner, C. A., Lorke, D. E., and Hermans-Borgmeyer, I. (2001). Expression of the Na-K-2Cl-cotransporter NKCC1 during mouse development. Mech. Dev. 102, 267-269. doi: 10.1016/S0925-4773(01)00309-4

Hung, C., and Chen, J. W. (2012). Treatment of post-traumatic epilepsy. Curr. Treat. Options Neurol. 14, 293-306. doi: 10.1007/s11940-0120178-5

Husson, Z., Rousseau, C. V., Broll, I., Zeilhofer, H. U., and Dieudonn,é, S. (2014). Differential GABAergic and glycinergic inputs of inhibitory interneurons and purkinje cells to principal cells of the cerebellar nuclei. J. Neurosci. 34, 9418-9431. doi: 10.1523/JNEUROSCI.0401-14.2014

Imbrici, P., Altamura, C., Pessia, M., Mantegazza, R., Desaphy, J.-F., and Camerino, D. C. (2015). ClC-1 chloride channels: state-of-the-art research and future challenges. Front. Cell. Neurosci. 9:156. doi: 10.3389/fncel.2015.00156

Ito, M. (2012). The Cerebellum: Brain for an Implicit Self. Upper Saddle River, NJ: FT press.

Ito, S. (2016). GABA and glycine in the developing brain. J. Physiol. Sci. 66, 375-379. doi: 10.1007/s12576-016-0442-7

Jacobs, S., Ruusuvuori, E., Sipil,ä, S. T., Haapanen, A., Damkier, H. H., Kurth, I., et al. (2008). Mice with targeted Slc4a10 gene disruption have small brain ventricles and show reduced neuronal excitability. Proc. Natl. Acad. Sci. U.S.A. 105, 311-316. doi: 10.1073/pnas. 0705487105

Jarolim, P., Shayakul, C., Prabakaran, D., Jiang, L., Stuart-Tilley, A., Rubin, H. L., et al. (1998). Autosomal dominant distal renal tubular acidosis is associated in three families with heterozygosity for the R589H mutation in the $\mathrm{AE} 1$ (band 3) $\mathrm{Cl}^{-} / \mathrm{HCO}^{-}$exchanger. J. Biol. Chem. 273, 6380-6388. doi: $10.1074 / \mathrm{jbc} .273 .11 .6380$

Jeck, N., Waldegger, S., Lampert, A., Boehmer, C., Waldegger, P., Lang, P. A., et al. (2004). Activating mutation of the renal epithelial chloride channel $\mathrm{ClC}-\mathrm{Kb}$ predisposing to hypertension. Hypertension 43, 1175-1181. doi: 10.1161/01.HYP.0000129824.12959.f0

Jentsch, T. J. (2008). CLC chloride channels and transporters: from genes to protein structure, pathology and physiology. Crit. Rev. Biochem. Mol. Biol. 43, 3-36. doi: $10.1080 / 10409230701829110$

Jentsch, T. J. (2015). Discovery of CLC transport proteins: cloning, structure, function and pathophysiology. J. Physiol. 593, 4091-4109. doi: 10.1113/JP270043

Jentsch, T. J. (2016). VRACs and other ion channels and transporters in the regulation of cell volume and beyond. Nat. Rev. Mol. Cell Biol. 17, 293-307. doi: $10.1038 / \mathrm{nrm} .2016 .29$

Jentsch, T. J., Stein, V., Weinreich, F., and Zdebik, A. A. (2002). Molecular structure and physiological function of chloride channels. Physiol. Rev. 82, 503-568. doi: 10.1152/physrev.00029.2001

Jin, X., Huguenard, J. R., and Prince, D. A. (2005). Impaired Cl- extrusion in layer $\mathrm{V}$ pyramidal neurons of chronically injured epileptogenic neocortex. $J$. Neurophysiol. 93, 2117-2126. doi: 10.1152/jn.00728.2004

Jin, X., Shah, S., Liu, Y., Zhang, H., Lees, M., Fu, Z., et al. (2013). Activation of the $\mathrm{Cl}$ - channel ANO1 by localized calcium signals in nociceptive sensory neurons requires coupling with the IP3 receptor. Sci. Signal. 6:ra73. doi: 10.1126/scisignal.2004184

Jourdain, P., Pavillon, N., Moratal, C., Boss, D., Rappaz, B., Depeursinge, C., et al. (2011). Determination of transmembrane water fluxes in neurons elicited by glutamate ionotropic receptors and by the cotransporters KCC2 and NKCC1: a digital holographic microscopy study. J. Neurosci. 31, 11846-11854. doi: 10.1523/JNEUROSCI.0286-11.2011

Jovov, B., Tousson, A., Mcmahon, L. L., and Benos, D. J. (2003). Immunolocalization of the acid-sensing ion channel $2 \mathrm{a}$ in the rat cerebellum. Histochem. Cell Biol. 119, 437-446. doi: 10.1007/s00418-003-0525-4

Jung, J., Nam, J. H., Park, H. W., Oh, U., Yoon, J.-H., and Lee, M. G. (2013). Dynamic modulation of ANO1/TMEM16A HCO3permeability by $\mathrm{Ca}^{2+} /$ calmodulin. Proc. Natl. Acad. Sci. 110, 360-365. doi: $10.1073 /$ pnas. 1211594110

Kahle, K. T., Barnett, S. M., Sassower, K. C., and Staley, K. J. (2009). Decreased seizure activity in a human neonate treated with bumetanide, an inhibitor 
of the Na+-K+-2Cl-cotransporter NKCC1. J. Child Neurol. 24, 572-576. doi: $10.1177 / 0883073809333526$

Kahle, K. T., Khanna, A. R., Alper, S. L., Adragna, N. C., Lauf, P. K., Sun, D., et al. (2015). K-Cl cotransporters, cell volume homeostasis, and neurological disease. Trends Mol. Med. 21, 513-523. doi: 10.1016/j.molmed.2015.05.008

Kahle, K. T., Khanna, A. R., Duan, J., Staley, K. J., Delpire, E., and Poduri, A. (2016). The KCC2 cotransporter and human epilepsy: getting excited about inhibition. Neuroscientist 22, 555-562. doi: 10.1177/1073858416645087

Kaila, K. (1994). Ionic basis of $\mathrm{GABA}_{\mathrm{A}}$ receptor channel function in the nervous system. Prog. Neurobiol. 42, 489-537. doi: 10.1016/0301-0082(94)90049-3

Kaila, K., and Voipio, J. (1987). Postsynaptic fall in intracellular pH induced by GABA-activated bicarbonate conductance. Nature 330, 163-165. doi: $10.1038 / 330163 \mathrm{a} 0$

Kanaka, C., Ohno, K., Okabe, A., Kuriyama, K., Itoh, T., Fukuda, A., et al. (2001). The differential expression patterns of messenger RNAs encoding $\mathrm{K}-\mathrm{Cl}$ cotransporters $(\mathrm{KCCl}, 2)$ and $\mathrm{Na}-\mathrm{K}-2 \mathrm{Cl}$ cotransporter (NKCC1) in the rat nervous system. Neuroscience 104, 933-946. doi: 10.1016/S0306-4522(01)00149-X

Kano, M., Rexhausen, U., Dreessen, J., and Konnerth, A. (1992). Synaptic excitation produces a long-lasting rebound potentiation of inhibitory synaptic signals in cerebellar Purkinje cells. Nature 356, 601-604. doi: 10.1038/356601a0

Karet, F., Gainza, F., Györy, A., Unwin, R., Wrong, O., Tanner, M., et al. (1998). Mutations in the chloride-bicarbonate exchanger gene AE1 cause autosomal dominant but not autosomal recessive distal renal tubular acidosis. Proc. Natl. Acad. Sci. U.S.A. 95, 6337-6342. doi: 10.1073/pnas.95.11.6337

Kasper, D., Planells-Cases, R., Fuhrmann, J. C., Scheel, O., Zeitz, O., Ruether, K., et al. (2005). Loss of the chloride channel ClC-7 leads to lysosomal storage disease and neurodegeneration. EMBO J. 24, 1079-1091. doi: $10.1038 /$ sj.emboj.7600576

Katoh, M. (2004). GDD1 is identical to TMEM16E, a member of the TMEM16 family. Am. J. Hum. Genet. 75, 927-928; author reply 928-929. doi: $10.1086 / 425341$

Kawa, K. (2003). Glycine facilitates transmitter release at developing synapses: a patch clamp study from Purkinje neurons of the newborn rat. Dev. Brain Res. 144, 57-71. doi: 10.1016/S0165-3806(03)00159-7

Kawakita, I., Uchigashima, M., Konno, K., Miyazaki, T., Yamasaki, M., and Watanabe, M. (2013). Type $2 \mathrm{~K}^{+}-\mathrm{Cl}^{-}$cotransporter is preferentially recruited to climbing fiber synapses during development and the stellate cell-targeting dendritic zone at adulthood in cerebellar Purkinje cells. Eur. J. Neurosci. 37, 532-543. doi: 10.1111/ejn.12076

Kawasaki, M., Uchida, S., Monkawa, T., Miyawaki, A., Mikoshiba, K., Marumo, F., et al. (1994). Cloning and expression of a protein kinase C-regulated chloride channel abundantly expressed in rat brain neuronal cells. Neuron 12, 597-604. doi: 10.1016/0896-6273(94)90215-1

Kim, K. H., Shcheynikov, N., Wang, Y., and Muallem, S. (2005). SLC26A7 is a Cl-channel regulated by intracellular pH. J. Biol. Chem. 280, 6463-6470. doi: 10.1074/jbc.M409162200

Kobayashi, K., Uchida, S., Okamura, H.-O., Marumo, F., and Sasaki, S. (2002). Human CLC-KB gene promoter drives the EGFP expression in the specific distal nephron segments and inner ear. J. Am. Soc. Nephrol. 13, 1992-1998. doi: 10.1097/01.ASN.0000023434.47132.3D

Konopacka, A., Qiu, J., Yao, S. T., Greenwood, M. P., Greenwood, M., Lancaster, T., et al. (2015). Osmoregulation requires brain expression of the renal Na-K-2Cl cotransporter NKCC2. J. Neurosci. 35, 5144-5155. doi: 10.1523/JNEUROSCI.4121-14.2015

Kopp, P. (2000). Pendred's syndrome and genetic defects in thyroid hormone synthesis. Rev. Endocr. Metab. Disord. 1, 109-121. doi: 10.1023/A:1010024722595

Kornak, U., Kasper, D., Bösl, M. R., Kaiser, E., Schweizer, M., Schulz, A., et al. (2001). Loss of the ClC-7 chloride channel leads to osteopetrosis in mice and man. Cell 104, 205-215. doi: 10.1016/S0092-8674(01)00206-9

Kros, L., Eelkman Rooda, O. H., Spanke, J. K., Alva, P., Dongen, M. N., Karapatis, A., et al. (2015). Cerebellar output controls generalized spike-and-wave discharge occurrence. Ann. Neurol. 77, 1027-1049. doi: 10.1002/ana.24399

Kursan, S., Mcmillen, T. S., Beesetty, P., Dias-Junior, E., Almutairi, M. M., Sajib, A. A., et al. (2017). The neuronal $\mathrm{K}+\mathrm{Cl}-\mathrm{co}$-transporter 2 (Slc12a5) modulates insulin secretion. Sci. Rep. 7:1732. doi: 10.1038/s41598-017-01814-0
Laurie, D. J., Seeburg, P., and Wisden, W. (1992). The distribution of 13 GABAA receptor subunit mRNAs in the rat brain. II. Olfactory bulb and cerebellum. J. Neurosci. 12, 1063-1076. doi: 10.1523/JNEUROSCI.12-11-04151.1992

Lavertu, G., Côté, S. L., and De Koninck, Y. (2013). Enhancing K-Cl co-transport restores normal spinothalamic sensory coding in a neuropathic pain model. Brain 137, 724-738. doi: 10.1093/brain/awt334

Lefler, Y., Yarom, Y., and Uusisaari, M. Y. (2014). Cerebellar inhibitory input to the inferior olive decreases electrical coupling and blocks subthreshold oscillations. Neuron 81, 1389-1400. doi: 10.1016/j.neuron.2014.02.032

Li, C., Cai, S., Wang, X., and Jiang, Z. (2015). Identification and characterization of ANO9 in stage II and III colorectal carcinoma. Oncotarget 6, 29324-29334. doi: 10.18632 /oncotarget.4979

Li, H., Tornberg, J., Kaila, K., Airaksinen, M. S., and Rivera, C. (2002). Patterns of cation-chloride cotransporter expression during embryonic rodent CNS development. Eur. J. Neurosci. 16, 2358-2370. doi: 10.1046/j.1460-9568.2002.02419.x

Li, X., Shimada, K., Showalter, L. A., and Weinman, S. A. (2000). Biophysical properties of ClC-3 differentiate it from swelling-activated chloride channels in Chinese hamster ovary-K1 cells. J. Biol. Chem. 275, 35994-35998. doi: 10.1074/jbc.M002712200

Liberman, M. C., Gao, J., He, D. Z., Wu, X., Jia, S., and Zuo, J. (2002). Prestin is required for electromotility of the outer hair cell and for the cochlear amplifier. Nature 419:300. doi: 10.1038/nature01059

Liu, J., Dai, Y., Li, X., Cao, K., Xie, D., Tong, Z., et al. (2017). Solute carrier family 12 member 5 promotes tumor invasion/metastasis of bladder urothelial carcinoma by enhancing NF-кB/MMP-7 signaling pathway. Cell Death Dis. 8:e2691. doi: 10.1038/cddis.2017.118

Liu, X. Z., Ouyang, X. M., Xia, X. J., Zheng, J., Pandya, A., Li, F., et al. (2003). Prestin, a cochlear motor protein, is defective in non-syndromic hearing loss. Hum. Mol. Genet. 12, 1155-1162. doi: 10.1093/hmg/ddg127

Liu, W., Lu, M., Liu, B., Huang, Y., and Wang, K. (2012). Inhibition of Ca 2+-activated $\mathrm{Cl}$ - channel ANO1/TMEM16A expression suppresses tumor growth and invasiveness in human prostate carcinoma. Cancer Lett. 326, 41-51. doi: $10.1016 /$ j.canlet.2012.07.015

Liu, Y., Xu, J.-Y., Wang, D.-K., Boron, W. F., and Chen, L.-M. (2011). Expression and distribution of NBCn2 (Slc4a10) splice variants in mouse brain: Cloning of novel variant NBCn2-D. Brain Res. 1390, 33-40. doi: 10.1016/j.brainres.2011.03.046

Llinás, R., and Yarom, Y. (1981a). Electrophysiology of mammalian inferior olivary neurones in vitro. Different types of voltage-dependent ionic conductances. J. Physiol. 315, 549-567. doi: 10.1113/jphysiol.1981.sp013763

Llinás, R., and Yarom, Y. (1981b). Properties and distribution of ionic conductances generating electroresponsiveness of mammalian inferior olivary neurones in vitro. J. Physiol. 315, 569-584. doi: 10.1113/jphysiol.1981.sp013764

Lohi, H., Kujala, M., Mäkelä, S., Lehtonen, E., Kestilä, M., Saarialho-Kere, U., et al. (2002). Functional characterization of three novel tissue-specific anion exchangers SLC26A7, -A8, and -A9. J. Biol. Chem. 277, 14246-14254. doi: 10.1074/jbc.M111802200

Lorenzetto, E., Caselli, L., Feng, G., Yuan, W., Nerbonne, J. M., Sanes, J. R., et al. (2009). Genetic perturbation of postsynaptic activity regulates synapse elimination in developing cerebellum. Proc. Natl. Acad. Sci. U.S.A. 106, 16475-16480. doi: 10.1073/pnas.0907298106

Lu, J., Karadsheh, M., and Delpire, E. (1999). Developmental regulation of the neuronal-specific isoform of $\mathrm{K}-\mathrm{Cl}$ cotransporter $\mathrm{KCC} 2$ in postnatal rat brains. Dev. Neurobiol. 39, 558-568. doi: 10.1002/(SICI)10974695(19990615)39:4<558::AID-NEU9>3.0.CO;2-5

Lynch, J. W. (2004). Molecular structure and function of the glycine receptor chloride channel. Physiol. Rev. 84, 1051-1095. doi: 10.1152/physrev.00042.2003

Lytle, C. (1997). Activation of the avian erythrocyte Na-K-Cl cotransport protein by cell shrinkage, cAMP, fluoride, and calyculin-A involves phosphorylation at common sites. J. Biol. Chem. 272, 15069-15077. doi: 10.1074/jbc.272.24.15069

MacAulay, N., Hamann, S., and Zeuthen, T. (2004). Water transport in the brain: role of cotransporters. Neuroscience 129, 1029-1042. doi: 10.1016/j.neuroscience.2004.06.045

Madison, D. V., Malenka, R. C., and Nicoll, R. A. (1986). Phorbol esters block a voltage-sensitive chloride current in hippocampal pyramidal cells. Nature 321, 695-697. doi: 10.1038/321695a0 
Majumdar, D., and Bevensee, M. O. (2010). Na-coupled bicarbonate transporters of the solute carrier 4 family in the nervous system: function, localization, and relevance to neurologic function. Neuroscience 171, 951-972. doi: 10.1016/j.neuroscience.2010.09.037

Mangin, J., Guyon, A., Eugene, D., Paupardin-Tritsch, D., and Legendre, P. (2002). Functional glycine receptor maturation in the absence of glycinergic input in dopaminergic neurones of the rat substantia nigra. J. Physiol. 542, 685-697. doi: 10.1113/jphysiol.2002.018978

Mcbain, C. J., and Fisahn, A. (2001). Interneurons unbound. Nat. Rev. Neurosci. 2, 11-23. doi: 10.1038/35049047

Mccool, B. A., and Botting, S. K. (2000). Characterization of strychnine-sensitive glycine receptors in acutely isolated adult rat basolateral amygdala neurons. Brain Res. 859, 341-351. doi: 10.1016/S0006-8993(00)02026-6

Merner, N. D., Mercado, A., Khanna, A. R., Hodgkinson, A., Bruat, V., Awadalla, P., et al. (2016). Gain-of-function missense variant in SLC12A2, encoding the bumetanide-sensitive NKCC1 cotransporter, identified in human schizophrenia. J. Psychiatr. Res. 77, 22-26. doi: 10.1016/j.jpsychires.2016.02.016

Mikawa, S., Wang, C., Shu, F., Wang, T., Fukuda, A., and Sato, K. (2002). Developmental changes in KCC1, KCC2 and NKCC1 mRNAs in the rat cerebellum. Dev. Brain Res. 136, 93-100. doi: 10.1016/S0165-3806(02)00345-0

Miltgen, M., Blanchard, A., Mathieu, H., Kreisler, A., Desvignes, J.-P., Salgado, D., et al. (2016). Novel heterozygous mutation in ANO3 responsible for craniocervical dystonia. Mov. Disord. 31, 1251-1252. doi: 10.1002/mds.26717

Mišković, N. D., Domingo, A., Dobričić, V., Max, C., Brænne, I., Petrović, I., et al. (2016). Seemingly dominant inheritance of a recessive ANO10 mutation in romani families with cerebellar ataxia. Mov. Disord. 31, 1929-1931. doi: $10.1002 / \mathrm{mds} .26816$

Mitchell, S. J., and Silver, R. A. (2000). GABA spillover from single inhibitory axons suppresses low-frequency excitatory transmission at the cerebellar glomerulus. J. Neurosci. 20, 8651-8658.

Möhler, H. (2006). GABA receptor diversity and pharmacology. Cell Tissue Res. 326, 505-516. doi: 10.1007/s00441-006-0284-3

Moore, Y. E., Kelley, M. R., Brandon, N. J., Deeb, T. Z., and Moss, S. J. (2017). Seizing control of KCC2: a new therapeutic target for epilepsy. Trends Neurosci. 40, 555-571. doi: 10.1016/j.tins.2017.06.008

Mount, D. B., and Romero, M. F. (2004). The SLC26 gene family of multifunctional anion exchangers. Pflügers Archiv. 447, 710-721. doi: 10.1007/s00424-003-1090-3

Nagao, S., Kwak, S., and Kanazawa, I. (1997). EAAT4, a glutamate transporter with properties of a chloride channel, is predominantly localized in Purkinje cell dendrites, and forms parasagittal compartments in rat cerebellum. Neuroscience 78, 929-933.

Namkung, W., Yao, Z., Finkbeiner, W. E., and Verkman, A. (2011). Small-molecule activators of TMEM16A, a calcium-activated chloride channel, stimulate epithelial chloride secretion and intestinal contraction. FASEB J. 25, 4048-4062. doi: 10.1096/fj.11-191627

Neureither, F., Ziegler, K., Pitzer, C., Frings, S., and Möhrlen, F. (2017). Impaired motor coordination and learning in mice lacking anoctamin 2 calcium-gated chloride channels. Cerebellum 16, 1-9. doi: 10.1007/s12311-017-0867-4

Ortinski, P. I., Lu, C., Takagaki, K., Fu, Z., and Vicini, S. (2004). Expression of distinct $\alpha$ subunits of GABA A receptor regulates inhibitory synaptic strength. J. Neurophysiol. 92, 1718-1727. doi: 10.1152/jn.00243.2004

Otis, T. S., Kavanaugh, M. P., and Jahr, C. E. (1997). Postsynaptic glutamate transport at the climbing fiber-Purkinje cell synapse. Science 277, 1515-1518. doi: 10.1126/science.277.5331.1515

Pace, A. J., Lee, E., Athirakul, K., Coffman, T. M., O’brien, D. A., and Koller, B. H. (2000). Failure of spermatogenesis in mouse lines deficient in the $\mathrm{Na}+-\mathrm{K}+-$ 2Cl-cotransporter. J. Clin. Invest. 105, 441-450. doi: 10.1172/JCI8553

Papp, E., Rivera, C., Kaila, K., and Freund, T. (2008). Relationship between neuronal vulnerability and potassium-chloride cotransporter 2 immunoreactivity in hippocampus following transient forebrain ischemia. Neuroscience 154, 677-689. doi: 10.1016/j.neuroscience.2008.03.072

Payne, J. A., Rivera, C., Voipio, J., and Kaila, K. (2003). Cation-chloride cotransporters in neuronal communication, development and trauma. Trends Neurosci. 26, 199-206. doi: 10.1016/S0166-2236(03)00068-7

Pearson, M., Lu, J., Mount, D., and Delpire, E. (2001). Localization of the K+-Clcotransporter, KCC3, in the central and peripheral nervous systems: expression in the choroid plexus, large neurons and white matter tracts. Neuroscience 103, 481-491. doi: 10.1016/S0306-4522(00)00567-4

Person, A. L., and Raman, I. M. (2012). Purkinje neuron synchrony elicits time-locked spiking in the cerebellar nuclei. Nature 481, 502-505. doi: $10.1038 /$ nature10732

Peter, S., Michiel, M., Stedehouder, J., Reinelt, C. M., Wu, B., Zhou, H., et al. (2016). Dysfunctional cerebellar Purkinje cells contribute to autism-like behaviour in Shank2-deficient mice. Nat. Commun. 7:12627. doi: 10.1038/ncomms12627

Petrovic, S., Barone, S., Xu, J., Conforti, L., Ma, L., Kujala, M., et al. (2004). SLC26A7: a basolateral Cl-/HCO 3-exchanger specific to intercalated cells of the outer medullary collecting duct. Am. J. Physiol. Renal Physiol. 286, F161-F169. doi: 10.1152/ajprenal.00219.2003

Petrovic, S., Ju, X., Barone, S., Seidler, U., Alper, S. L., Lohi, H., et al. (2003). Identification of a basolateral $\mathrm{Cl}-/ \mathrm{HCO} 3-$ exchanger specific to gastric parietal cells. Am. J. Physiol. Gastrointest. Liver Physiol. 284, G1093-G1103. doi: 10.1152/ajpgi.00454.2002

Picollo, A., Malvezzi, M., and Accardi, A. (2015). TMEM16 proteins: unknown structure and confusing functions. J. Mol. Biol. 427, 94-105. doi: 10.1016/j.jmb.2014.09.028

Pifferi, S., Dibattista, M., and Menini, A. (2009). TMEM16B induces chloride currents activated by calcium in mammalian cells. Pflügers Arch. 458, 1023-1038. doi: 10.1007/s00424-009-0684-9

Pirker, S., Schwarzer, C., Wieselthaler, A., Sieghart, W., and Sperk, G. (2000). GABA(A) receptors: immunocytochemical distribution of 13 subunits in the adult rat brain. Neuroscience 101, 815-850. doi: 10.1016/S0306-4522(00)00442-5

Pizzarelli, R., and Cherubini, E. (2011). Alterations of GABAergic signaling in autism spectrum disorders. Neural Plast. 2011:297153. doi: $10.1155 / 2011 / 297153$

Planells-Cases, R., and Jentsch, T. J. (2009). Chloride channelopathies. Biochim. Biophys. Acta 1792, 173-189. doi: 10.1016/j.bbadis.2009.02.002

Plotkin, M., Snyder, E., Hebert, S., and Delpire, E. (1997). Expression of the $\mathrm{Na}-\mathrm{K}-2 \mathrm{Cl}$ cotransporter is developmentally regulated in postnatal rat brains: a possible mechanism underlying GABA's excitatory role in immature brain. J. Neurobiol. 33, 781-795. doi: 10.1002/(SICI)10974695(19971120)33:6<781::AID-NEU6>3.0.CO;2-5

Poët, M., Kornak, U., Schweizer, M., Zdebik, A. A., Scheel, O., Hoelter, S., et al. (2006). Lysosomal storage disease upon disruption of the neuronal chloride transport protein ClC-6. Proc. Natl. Acad. Sci. U.S.A. 103, 13854-13859. doi: 10.1073/pnas.0606137103

Pond, B. B., Berglund, K., Kuner, T., Feng, G., Augustine, G. J., and SchwartzBloom, R. D. (2006). The chloride transporter $\mathrm{Na}+-\mathrm{K}+-\mathrm{Cl}-$ cotransporter isoform-1 contributes to intracellular chloride increases after in vitro ischemia. J. Neurosci. 26, 1396-1406. doi: 10.1523/JNEUROSCI.1421-05.2006

Porter, N. M., Angelotti, T. P., Twyman, R., and Macdonald, R. L. (1992). Kinetic properties of alpha 1 beta 1 gamma-aminobutyric acidA receptor channels expressed in Chinese hamster ovary cells: regulation by pentobarbital and picrotoxin. Mol. Pharmacol. 42, 872-881.

Rahmati, N. (2015). The Role of Chloride Homeostasis in the Olivocerebellar System. Ridderkerk: Ridderprint BV.

Rahmati, N., Kunzelmann, K., Xu, J., Barone, S., Sirianant, L., De Zeeuw, C. I., et al. (2013). Slc26a11 is prominently expressed in the brain and functions as a chloride channel: expression in Purkinje cells and stimulation of V H+-ATPase. Pflügers Arch. 465, 1583-1597. doi: 10.1007/s00424-013-1300-6

Rahmati, N., Veloz, M. F. V., Xu, J., Barone, S., Hamida, N. R. B., Schonewille, M., et al. (2016). SLC26A11 (KBAT) in Purkinje cells is critical for inhibitory transmission and contributes to locomotor coordination. eNeuro 3, 1-16. doi: 10.1523/ENEURO.0028-16.2016

Ratté, S., and Prescott, S. A. (2011). ClC-2 channels regulate neuronal excitability, not intracellular chloride levels. J. Neurosci. 31, 15838-15843. doi: 10.1523/JNEUROSCI.2748-11.2011

Reardon, W., and Trembath, R. (1996). Pendred syndrome. J. Med. Genet. 33:1037. doi: 10.1136/jmg.33.12.1037

Renaud, M., Anheim, M., Kamsteeg, E.-J., Mallaret, M., Mochel, F., Vermeer, S., et al. (2014). Autosomal recessive cerebellar ataxia type 3 due to ANO10 mutations: delineation and genotype-phenotype correlation study. JAMA Neurol. 71, 1305-1310. doi: 10.1001/jamaneurol.2014.193 
Rinehart, J., Maksimova, Y. D., Tanis, J. E., Stone, K. L., Hodson, C. A., Zhang, J., et al. (2009). Sites of regulated phosphorylation that control K-Cl cotransporter activity. Cell 138, 525-536. doi: 10.1016/j.cell.2009.05.031

Rinke, I., Artmann, J., and Stein, V. (2010). ClC-2 voltage-gated channels constitute part of the background conductance and assist chloride extrusion. J. Neurosci. 30, 4776-4786. doi: 10.1523/JNEUROSCI.6299-09.2010

Rivera, C., Voipio, J., Payne, J. A., and Ruusuvuori, E. (1999). The K+/Cl-cotransporter KCC2 renders GABA hyperpolarizing during neuronal maturation. Nature 397, 251-255. doi: 10.1038/16697

Robinson, M. B., and Dowd, L. A. (1996). Heterogeneity and functional properties of subtypes of sodium-dependent glutamate transporters in the mammalian central nervous system. Adv. Pharmacol. 37, 69-115. doi: 10.1016/S1054-3589(08)60948-5

Rocha, A. S., and Kokko, J. P. (1973). Sodium chloride and water transport in the medullary thick ascending limb of Henle. Evidence for active chloride transport. J. Clin. Invest. 52, 612-623. doi: 10.1172/JCI107223

Romero, M. F., Chen, A.-P., Parker, M. D., and Boron, W. F. (2013). The SLC4 family of bicarbonate transporters. Mol. Aspects Med. 34, 159-182. doi: 10.1016/j.mam.2012.10.008

Rossi, D. J., and Hamann, M. (1998). Spillover-mediated transmission at inhibitory synapses promoted by high affinity $\alpha 6$ subunit GABAA receptors and glomerular geometry. Neuron 20, 783-795. doi: 10.1016/S0896-6273(00)81016-8

Ruffin, V. A., Salameh, A. I., Boron, W. F., and Parker, M. D. (2014). Intracellular $\mathrm{pH}$ regulation by acid-base transporters in mammalian neurons. Front. Physiol. 5:43. doi: 10.3389/fphys.2014.00043

Rungta, R. L., Choi, H. B., Tyson, J. R., Malik, A., Dissing-Olesen, L., Lin, P. J., et al. (2015). The cellular mechanisms of neuronal swelling underlying cytotoxic edema. Cell 161, 610-621. doi: 10.1016/j.cell.2015.03.029

Russell, J. M. (2000). Sodium-potassium-chloride cotransport. Physiol. Rev. 80, 211-276. doi: 10.1152/physrev.2000.80.1.211

Sander, T., Toliat, M. R., Heils, A., Leschik, G., Becker, C., Rüschendorf, F., et al. (2002). Association of the 867Asp variant of the human anion exchanger 3 gene with common subtypes of idiopathic generalized epilepsy. Epilepsy Res. 51, 249-255. doi: 10.1016/S0920-1211(02)00152-3

Sangan, P., Rajendran, V. M., Geibel, J. P., and Binder, H. J. (2002). Cloning and expression of a chloride-dependent $\mathrm{Na}+\mathrm{H}+$ exchanger. J. Biol. Chem. 277, 9668-9675. doi: 10.1074/jbc.M110852200

Satoh, H., Qu, L., Suzuki, H., and Saitow, F. (2013). Depolarization-induced depression of inhibitory transmission in cerebellar Purkinje cells. Physiol. Rep. 1:e00061. doi: 10.1002/phy2.61

Schwake, M., Friedrich, T., and Jentsch, T. J. (2001). An internalization signal in ClC-5, an endosomal $\mathrm{Cl}^{-}$channel mutated in Dent's disease. J. Biol. Chem. 276, 12049-12054. doi: 10.1074/jbc.M010642200

Schweizer, C., Balsiger, S., Bluethmann, H., Mansuy, I. M., Fritschy, J.-M., Mohler, H., et al. (2003). The $\gamma 2$ subunit of GABAA receptors is required for maintenance of receptors at mature synapses. Mol. Cell. Neurosci. 24, 442-450. doi: 10.1016/S1044-7431(03)00202-1

Sedmak, G., Jovanov-Milošević, N., Puskarjov, M., Ulamec, M., Krušlin, B., Kaila, K., et al. (2016). Developmental expression patterns of KCC2 and functionally associated molecules in the human brain. Cereb. Cortex 26, 4574-4589. doi: 10.1093/cercor/bhv218

Seja, P., Schonewille, M., Spitzmaul, G., Badura, A., Klein, I., Rudhard, Y., et al. (2012). Raising cytosolic $\mathrm{Cl}-$ in cerebellar granule cells affects their excitability and vestibulo-ocular learning. EMBO J. 31, 1217-1230. doi: 10.1038/emboj.2011.488

Shayakul, C., and Alper, S. L. (2004). Defects in processing and trafficking of the $\mathrm{AE} 1 \mathrm{Cl}^{-} / \mathrm{HCO}_{3}^{-}$exchanger associated with inherited distal renal tubular acidosis. J. Clin. Exp. Nephrol. 8, 1-11. doi: 10.1007/s10157-003-0271-x

Shiang, R., Ryan, S. G., Zhu, Y.-Z., Hahn, A. F., O'connell, P., and Wasmuth, J. J. (1993). Mutations in the $\alpha 1$ subunit of the inhibitory glycine receptor cause the dominant neurologic disorder, hyperekplexia. Nat. Genet. 5, 351-358. doi: $10.1038 / n g 1293-351$

Shimizu, T., Iehara, T., Sato, K., Fujii, T., Sakai, H., and Okada, Y. (2013). TMEM16F is a component of a $\mathrm{Ca}^{2+}$-activated $\mathrm{Cl}^{-}$channel but not a volumesensitive outwardly rectifying $\mathrm{Cl}^{-}$channel. Am. J. Physiol. Cell Physiol. 304, C748-C759. doi: 10.1152/ajpcell.00228.2012
Sieghart, W., and Sperk, G. (2002). Subunit composition, distribution and function of GABA-A receptor subtypes. Curr. Top. Med. Chem. 2, 795-816. doi: $10.2174 / 1568026023393507$

Sigel, E., and Steinmann, M. E. (2012). Structure, function, and modulation of GABAA receptors. J. Biol. Chem. 287, 40224-40231. doi: $10.1074 /$ jbc.R112.386664

Sík, A., Smith, R., and Freund, T. (2000). Distribution of chloride channel2 -immunoreactive neuronal and astrocytic processes in the hippocampus. Neuroscience 101, 51-65. doi: 10.1016/S0306-4522(00)00360-2

Simon, D. B., Karet, F. E., Hamdan, J. M., Di Pietro, A., Sanjad, S. A., and Lifton, R. P. (1996). Bartter's syndrome, hypokalaemic alkalosis with hypercalciuria, is caused by mutations in the $\mathrm{Na}-\mathrm{K}-2 \mathrm{Cl}$ cotransporter NKCC2. Nat. Genet. 13:183. doi: 10.1038/ng0696-183

Smith, R., Clayton, G., Wilcox, C., Escudero, K., and Staley, K. (1995). Differential expression of an inwardly rectifying chloride conductance in rat brain neurons: a potential mechanism for cell-specific modulation of postsynaptic inhibition. J. Neurosci. 15, 4057-4067.

Soleimani, M. (2001). Molecular physiology of the renal chlorideformate exchanger. Curr. Opin. Nephrol. Hypertens. 10, 677-683. doi: 10.1097/00041552-200109000-00020

Soleimani, M. (2013). SLC26 Cl-/HCO3-exchangers in the kidney: roles in health and disease. Kidney Int. 84, 657-666. doi: 10.1038/ki.2013.138

Soleimani, M., and Xu, J. (2006). SLC26 chloride/base exchangers in the kidney in health and disease. Semin. Nephrol. 26, 375-385. doi: 10.1016/j.semnephrol.2006.07.005

Song, L., Mercado, A., Vázquez, N., Xie, Q., Desai, R., George, A. L., et al. (2002). Molecular, functional, and genomic characterization of human KCC2, the neuronal K-Cl cotransporter. Mol. Brain Res. 103, 91-105. doi: 10.1016/S0169-328X(02)00190-0

Staley, K. (2011). Carts, horses, and push-pull regulation of EGABA in neonatal seizures. Epilepsy Curr. 11, 205-208. doi: 10.5698/1535-7511-11.6.205

Staley, K., Smith, R., Schaack, J., Wilcox, C., and Jentsch, T. J. (1996). Alteration of GABA A receptor function following gene transfer of the CLC-2 chloride channel. Neuron 17, 543-551. doi: 10.1016/S0896-6273(00)80186-5

Stehberger, P. A., Shmukler, B. E., Stuart-Tilley, A. K., Peters, L. L., Alper, S. L., and Wagner, C. A. (2007). Distal renal tubular acidosis in mice lacking the AE1 (band3) $\mathrm{Cl}^{-} / \mathrm{HCO}_{3}^{-}$exchanger (slc4a1). J. Am. Soc. Nephrol. 18, 1408-1418. doi: $10.1681 /$ ASN.2006101072

Stein, V., Hermans-Borgmeyer, I., Jentsch, T. J., and Hübner, C. A. (2004), Expression of the $\mathrm{KCl}$ cotransporter $\mathrm{KCC} 2$ parallels neuronal maturation and the emergence of low intracellular chloride. J. Comp. Neurol. 468, 57-64. doi: 10.1002/cne.10983

Steinmeyer, K., and Klocke, R. (1991). Inactivation of muscle chloride channel by transposon insertion in myotonic mice. Nature 354, 304-308. doi: $10.1038 / 354304 \mathrm{a} 0$

Stephan, A. B., Shum, E. Y., Hirsh, S., Cygnar, K. D., Reisert, J., and Zhao, H. (2009). ANO2 is the cilial calcium-activated chloride channel that may mediate olfactory amplification. Proc. Nat. Acad. Sci. U.S.A. 106, 11776-11781. doi: 10.1073/pnas.0903304106

Stobrawa, S. M., Breiderhoff, T., Takamori, S., Engel, D., Schweizer, M., Zdebik, A. A., et al. (2001). Disruption of ClC-3, a chloride channel expressed on synaptic vesicles, leads to a loss of the hippocampus. Neuron 29, 185-196. doi: 10.1016/S0896-6273(01)00189-1

Stöhr, H., Heisig, J. B., Benz, P. M., Schöberl, S., Milenkovic, V. M., Strauss, O., et al. (2009). TMEM16B, a novel protein with calcium-dependent chloride channel activity, associates with a presynaptic protein complex in photoreceptor terminals. J. Neurosci. 29, 6809-6818. doi: 10.1523/JNEUROSCI.5546-08.2009

Succol, F., Fiumelli, H., Benfenati, F., Cancedda, L., and Barberis, A. (2012). Intracellular chloride concentration influences the GABAA receptor subunit composition. Nat. Commun. 3:738. doi: 10.1038/ncomms1744

Sung, K.-W., Kirby, M., Mcdonald, M. P., Lovinger, D. M., and Delpire, E. (2000). Abnormal $\mathrm{GABA}_{\mathrm{A}}$ receptor-mediated currents in dorsal root ganglion neurons isolated from $\mathrm{Na}-\mathrm{K}-2 \mathrm{Cl}$ cotransporter null mice. J. Neurosci. 20, $7531-7538$.

Suzuki, J., Fujii, T., Imao, T., Ishihara, K., Kuba, H., and Nagata, S. (2013). Calciumdependent phospholipid scramblase activity of TMEM16 protein family members. J. Biol. Chem. 288, 13305-13316. doi: 10.1074/jbc.M113.457937 
Suzuki, J., Umeda, M., Sims, P. J., and Nagata, S. (2010). Calciumdependent phospholipid scrambling by TMEM16F. Nature 468, 834-838. doi: 10.1038 /nature09583

Szapiro, G., and Barbour, B. (2007). Multiple climbing fibers signal to molecular layer interneurons exclusively via glutamate spillover. Nat. Neurosci. 10, 735-742. doi: 10.1038/nn1907

Takahashi, M., Sarantis, M., and Attwell, D. (1996). Postsynaptic glutamate uptake in rat cerebellar Purkinje cells. J. Physiol. 497, 523-530. doi: 10.1113/jphysiol.1996.sp021785

Takayama, C., and Inoue, Y. (2007). Developmental localization of potassium chloride co-transporter 2 (KCC2) in the Purkinje cells of embryonic mouse cerebellum. Neurosci. Res. 57, 322-325. doi: 10.1016/j.neures.2006.10.016

Tanaka, J., Ichikawa, R., Watanabe, M., Tanaka, K., and Inoue, Y. (1997). Extra-junctional localization of glutamate transporter EAAT4 at excitatory Purkinje cell synapses. Neuroreport 8, 2461-2464. doi: 10.1097/00001756-199707280-00010

Tang, C.-M., Dichter, M., and Morad, M. (1990). Modulation of the N-methylD-aspartate channel by extracellular H+. Proc. Natl. Acad. Sci. U.S.A. 87, 6445-6449. doi: 10.1073/pnas.87.16.6445

Tombaugh, G. C., and Somjen, G. G. (1996). Effects of extracellular pH on voltagegated $\mathrm{Na}+, \mathrm{K}+$ and $\mathrm{Ca} 2+$ currents in isolated rat CA1 neurons. J. Physiol. 493, 719-732. doi: 10.1113/jphysiol.1996.sp021417

Tong, C.-K., and Chesler, M. (1999). Activity-evoked extracellular pH shifts in slices of rat dorsal lateral geniculate nucleus. Brain Res. 815, 373-381. doi: 10.1016/S0006-8993(98)01059-2

Touré, A., Morin, L., Pineau, C., Becq, F., Dorseuil, O., and Gacon, G. (2001). Tat1, a novel sulfate transporter specifically expressed in human male germ cells and potentially linked to rhogtpase signaling. J. Biol. Chem. 276, 20309-20315. doi: 10.1074/jbc.M011740200

Traynelis, S. F., and Cull-Candy, S. G. (1990). Proton inhibition of Nmethyl-D-aspartate receptors in cerebellar neurons. Nature 345, 347-350. doi: $10.1038 / 345347 \mathrm{a} 0$

Tsai, P. T., Chu, Y., Greene-Colozzi, E., Sadowski, A. R., Leech, J. M., Steinberg, J., et al. (2012). Autistic-like behaviour and cerebellar dysfunction in Purkinje cell Tsc1 mutant mice. Nature 488, 647-651. doi: 10.1038/nature11310

Tsutsumi, S., Kamata, N., Vokes, T. J., Maruoka, Y., Nakakuki, K., Enomoto, S., et al. (2004). The novel gene encoding a putative transmembrane protein is mutated in gnathodiaphyseal dysplasia (GDD). Am. J. Hum. Genet. 74, 1255-1261. doi: 10.1086/421527

Ubby, I., Bussani, E., Colonna, A., Stacul, G., Locatelli, M., Scudieri, P., et al. (2013). TMEM16A alternative splicing coordination in breast cancer. Mol. Cancer 12:75. doi: 10.1186/1476-4598-12-75

Vandewalle, A., Cluzeaud, F., Peng, K.-C., Bens, M., Lüchow, A., Günther, W., et al. (2001). Tissue distribution and subcellular localization of the $\mathrm{ClC}-5$ chloride channel in rat intestinal cells. Am. J. Physiol. Cell Physiol. 280, C373-C381. doi: 10.1152/ajpcell.2001.280.2.C373

Veloz, M. F. V., Zhou, K., Bosman, L. W., Potters, J.-W., Negrello, M., Seepers, R. M., et al. (2015). Cerebellar control of gait and interlimb coordination. Brain Struct. Funct. 220, 3513-3536. doi: 10.1007/s00429-014-0870-1

Verdoorn, T. A., Draguhn, A., Ymer, S., Seeburg, P. H., and Sakmann, B. (1990). Functional properties of recombinant rat GABA A receptors depend upon subunit composition. Neuron 4, 919-928. doi: 10.1016/0896-6273(90)90145-6

Verkman, A. S., and Galietta, L. J. (2009). Chloride channels as drug targets. Nature Rev. Drug Discov. 8, 153-171. doi: 10.1038/nrd2780

Vermeer, S., Hoischen, A., Meijer, R. P., Gilissen, C., Neveling, K., Wieskamp, N., et al. (2010). Targeted next-generation sequencing of a $12.5 \mathrm{Mb}$ homozygous region reveals ANO10 mutations in patients with autosomal-recessive cerebellar ataxia. Am. J. Hum. Genet. 87, 813-819. doi: 10.1016/j.ajhg.2010.10.015

Vincourt, J.-B., Jullien, D., Amalric, F., and Girard, J.-P. (2003). Molecular and functional characterization of SLC26A11, a sodium-independent sulfate transporter from high endothelial venules. FASEB J. 17, 890-892. doi: 10.1096/fj.02-0787fje

Vocke, K., Dauner, K., Hahn, A., Ulbrich, A., Broecker, J., Keller, S., et al. (2013). Calmodulin-dependent activation and inactivation of anoctamin calcium-gated chloride channels. J. Gen. Physiol. 142, 381-404. doi: 10.1085/jgp.201311015
Wadiche, J. I., Amara, S. G., and Kavanaugh, M. P. (1995). Ion fluxes associated with excitatory amino acid transport. Neuron 15, 721-728. doi: 10.1016/0896-6273(95)90159-0

Wang, X. Q., Deriy, L. V., Foss, S., Huang, P., Lamb, F. S., Kaetzel, M. A., et al. (2006). CLC-3 channels modulate excitatory synaptic transmission in hippocampal neurons. Neuron 52, 321-333. doi: 10.1016/j.neuron.2006. 08.035

Wanitchakool, P., Ousingsawat, J., Sirianant, L., Cabrita, I., Faria, D., Schreiber, R., et al. (2017). Cellular defects by deletion of ANO10 are due to deregulated local calcium signaling. Cell. Signal. 30, 41-49. doi: 10.1016/j.cellsig.2016.11.00

Watanabe, D., Inokawa, H., Hashimoto, K., Suzuki, N., Kano, M., Shigemoto, R., et al. (1998). Ablation of cerebellar Golgi cells disrupts synaptic integration involving GABA inhibition and NMDA receptor activation in motor coordination. Cell 95, 17-27. doi: 10.1016/S0092-8674(00)81779-1

Wei, W. C., Akerman, C. J., Newey, S. E., Pan, J., Clinch, N. W., Jacob, Y., et al. (2011). The potassium-chloride cotransporter 2 promotes cervical cancer cell migration and invasion by an ion transport-independent mechanism. J. Physiol. 589, 5349-5359. doi: 10.1113/jphysiol.2011.214635

Weinreich, F., and Jentsch, T. J. (2001). Pores formed by single subunits in mixed dimers of different CLC chloride channels. J. Biol. Chem. 276, 2347-2353. doi: 10.1074/jbc.M005733200

Werman, R., Davidoff, R., and Aprison, M. (1968). Inhibitory of glycine on spinal neurons in the cat. J. Neurophysiol. 31, 81-95. doi: 10.1152/jn.1968.31.1.81

Whittington, M. A., and Traub, R. D. (2003). Interneuron diversity series: inhibitory interneurons and network oscillations in vitro. Trends Neurosci. 26, 676-682. doi: 10.1016/j.tins.2003. 09.016

Williams, J. R., Sharp, J. W., Kumari, V. G., Wilson, M., and Payne, J. A. (1999). The neuron-specific K-Cl cotransporter, KCC2 antibody development and initial characterization of the protein. J. Biol. Chem. 274, 12656-12664. doi: $10.1074 /$ jbc.274.18.12656

Wisden, W. (1995). Structure and distribution of multiple GABAA receptor subunits with special reference to the cerebellum. Ann. N. Y. Acad. Sci. 757, 506-515. doi: 10.1111/j.1749-6632.1995.tb17510.x

Wisden, W., Murray, A. J., Mcclure, C., and Wulff, P. (2009). Studying cerebellar circuits by remote control of selected neuronal types with GABAA receptors. Front. Mol. Neurosci. 2:29. doi: 10.3389/neuro.02.029.2009

Wulff, P., Schonewille, M., Renzi, M., Viltono, L., Sassoè-Pognetto, M., Badura, A., et al. (2009). Synaptic inhibition of Purkinje cells mediates consolidation of vestibulo-cerebellar motor learning. Nat. Neurosci. 12, 1042-1049. doi: 10.1038/nn.2348

Xie, Q., Welch, R., Mercado, A., Romero, M. F., and Mount, D. B. (2002). Molecular characterization of the murine Slc26a6 anion exchanger: functional comparison with Slc26a1. Am. J. Physiol. Renal Physiol. 283, F826-F838. doi: 10.1152/ajprenal.00079.2002

Xie, Z., Currie, K., Cahill, A. L., and Fox, A. P. (2003). Role of $\mathrm{Cl}^{-}$co-transporters in the excitation produced by $\mathrm{GABA}_{\mathrm{A}}$ receptors in juvenile bovine adrenal chromaffin cells. J. Neurophysiol. 90, 3828-3837. doi: 10.1152/jn.00617.2003

Xu, J., Barone, S., Li, H., Holiday, S., Zahedi, K., and Soleimani, M. (2011). Slc26a11, a chloride transporter, localizes with the vacuolar $\mathrm{H}+$ ATPase of A-intercalated cells of the kidney. Kidney Int. 80, 926-937. doi: $10.1038 / \mathrm{ki} .2011 .196$

Xu, J., Henriksnas, J., Barone, S., Witte, D., Shull, G. E., Forte, J. G., et al. (2005). SLC26A9 is expressed in gastric surface epithelial cells, mediates $\mathrm{Cl}^{-} / \mathrm{HCO}^{-}$ exchange, and is inhibited by NH4 ${ }^{+}$. Am. J. Physiol. Cell Physiol. 289, C493C505. doi: 10.1152/ajpcell.00030.2005

Xu, J., Worrell, R. T., Li, H. C., Barone, S. L., Petrovic, S., Amlal, H., et al. (2006). Chloride/bicarbonate exchanger SLC26A7 is localized in endosomes in medullary collecting duct cells and is targeted to the basolateral membrane in hypertonicity and potassium depletion. J. Am. Soc. Nephrol. 17, 956-967. doi: 10.1681/ASN.2005111174

Xue, H., Liu, S., Ji, T., Ren, W., Zhang, X., Zheng, L., et al. (2009). Expression of NKCC2 in the rat gastrointestinal tract. Neurogastroenterol. Motil. 21:1068. doi: 10.1111/j.1365-2982.2009.01334.x

Yang, Y. D., Cho, H., Koo, J. Y., Tak, M. H., Cho, Y., Shim, W.-S., et al. (2008). TMEM16A confers receptor-activated calcium-dependent chloride conductance. Nature 455, 1210-1215. doi: 10.1038/nature07313 
Yang, H., Kim, A., David, T., Palmer, D., Jin, T., Tien, J., et al. (2012). TMEM16F forms a $\mathrm{Ca}^{2+}$-activated cation channel required for lipid scrambling in platelets during blood coagulation. Cell 151, 111-122. doi: 10.1016/j.cell.2012.07.036

Ye, J.-H. (2007). "Regulation of excitation by glycine receptors," in Inhibitory Regulation of Excitatory Neurotransmission (Berlin; Heidelberg: Springer), 123-143.

Ye, J. H., Schaefer, R., Wu, W.-H., Liu, P. L., Zbuzek, V. K., and Mcardle, J. J. (1999). Inhibitory effect of ondansetron on glycine response of dissociated rat hippocampal neurons. J. Pharmacol. Exp. Ther. 290, 104-111.

Yu, C., Yu, J., Yao, X., Wu, W. K., Lu, Y., Tang, S., et al. (2014). Discovery of biclonal origin and a novel oncogene SLC12A5 in colon cancer by single-cell sequencing. Cell Res. 24:701. doi: 10.1038/cr.2014.43

Yu, K., Whitlock, J. M., Lee, K., Ortlund, E. A., Cui, Y. Y., and Hartzell, H. C. (2015). Identification of a lipid scrambling domain in ANO6/TMEM16F. Elife 4:e06901. doi: 10.7554/eLife.06901

Zarbin, M. A., Wamsley, J. K., and Kuhar, M. J. (1981). Glycine receptor: light microscopic autoradiographic localization with $[3 \mathrm{H}]$ strychnine. J. Neurosci. 1 , 532-547. doi: 10.1523/JNEUROSCI.01-05-00532.1981

Zeeuw, C., and Berrebi, A. (1995). Postsynaptic targets of Purkinje cell terminals in the cerebellar and vestibular nuclei of the rat. Eur. J. Neurosci. 7, 2322-2333. doi: 10.1111/j.1460-9568.1995.tb00653.x

Zeuthen, T. (2010). Water-transporting proteins. J. Membr. Biol. 234, 57-73. doi: 10.1007/s00232-009-9216-y

Zhan, R.-Z., Fujiwara, N., Tanaka, E., and Shimoji, K. (1998). Intracellular acidification induced by membrane depolarization in rat hippocampal slices: roles of intracellular $\mathrm{Ca}^{2+}$ and glycolysis. Brain Res. 780, 86-94 doi: 10.1016/S0006-8993(97)01149-9

Zhang, W., Schmelzeisen, S., Parthier, D., Frings, S., and Möhrlen, F. (2015). Anoctamin calcium-activated chloride channels may modulate inhibitory transmission in the cerebellar cortex. PLoS ONE 10:e142160. doi: 10.1371/journal.pone.0142160

Zhang, Y., Zhang, Z., Xiao, S., Tien, J., Le, S., Le, T., et al. (2017). Inferior Olivary TMEM16B mediates cerebellar motor learning. Neuron 95, 1103. e1104-1111. e1104. doi: 10.1016/j.neuron.2017. 08.010

Zhou, H., Lin, Z., Voges, K., Ju, C., Gao, Z., Bosman, L. W., et al. (2014). Cerebellar modules operate at different frequencies. Elife 3:e02536. doi: 10.7554/eLife.02536

Conflict of Interest Statement: The authors declare that the research was conducted in the absence of any commercial or financial relationships that could be construed as a potential conflict of interest.

Copyright (c) 2018 Rahmati, Hoebeek, Peter and De Zeeuw. This is an open-access article distributed under the terms of the Creative Commons Attribution License (CC $B Y)$. The use, distribution or reproduction in other forums is permitted, provided the original author(s) and the copyright owner are credited and that the original publication in this journal is cited, in accordance with accepted academic practice. No use, distribution or reproduction is permitted which does not comply with these terms. 